\title{
A Comparison Between Dispersed Nuclear Power Plants and a Nuclear Energy Center at a Hypothetical Site on Kentucky Lake, Tennessee
}

\section{Vol. IV. A Site Selection Methodology}

\section{S. Rosemarin \\ S. L. Yaffee}

PORTIONS OF THIS REPORT ARE ILIEGTBLE. It

has been reproduced from the best available

copy to permit the broadest possible avail-

ability.

\section{OAK RIDGE NATIONAL LABORATORY}

OPERATED BY UNION CARBIDE CORPORATION FOR THE ENERGY RESEARCH AND DEVELOPMENT ADMINISTRATION 


\section{DISCLAIMER}

This report was prepared as an account of work sponsored by an agency of the United States Government. Neither the United States Government nor any agency Thereof, nor any of their employees, makes any warranty, express or implied, or assumes any legal liability or responsibility for the accuracy, completeness, or usefulness of any information, apparatus, product, or process disclosed, or represents that its use would not infringe privately owned rights. Reference herein to any specific commercial product, process, or service by trade name, trademark, manufacturer, or otherwise does not necessarily constitute or imply its endorsement, recommendation, or favoring by the United States Government or any agency thereof. The views and opinions of authors expressed herein do not necessarily state or reflect those of the United States Government or any agency thereof. 


\section{DISCLAIMER}

Portions of this document may be illegible in electronic image products. Images are produced from the best available original document. 


\section{Printed in the United States of America. Available from National Technical Information Service U.S. Department of Sonmmerce 5285 Port Royal Road, Springfield, Virginia 22161 \\ Price: Printed Copy $\$ 5.00$; Microfiche $\$ 2.25$}

This report was prepared as an account of work sponsored by the United States Government. Neither the United States nor the Energy Research and Development Administration, nor any of their employees, nor any of their contractors, subcontractors, or their employees, makes any warranty, express or implied, or assumes any legal liability or responsibility for the accuracy, completeness or usefulness of any information, apparatus, product or process disclosed, or represents that its use would not infringe privately owned rights.

The complete report is composed of the following volumes:

Vu1. I. Summary (ORNL/'I'M-5310)

Vo1. II. Transmission of Power (ORNL/TM-5311)

Vo1. III. Environmental Considerations (ORNL/TM-5312)

Vo1. IV. A Site Selection Methodology (ORNL/TM-5313) 


\author{
ORNL/TM-5313 \\ (Fourth Volume of ORNL/TM-5310) \\ Dist. Category UC-80
}

Contract No. W-7405-eng-26

ENERGY DIVISION

A COMPARISON BETWEEN DISPERSED NUCLEAR POWER PLANTS

AND A NUCLEAR ENERGY CENTER AT A HYPOTHETICAL SITE

ON KENTUCKY LAKE, TENNESSEE

VOL. IV. A SITE SELECTION METHODOLOGY

C. S. Rosemarin

S. L. Yaffee

This study was performed for the Nuclear Regulatory Commission in connection with the development of their Nuclear Energy Center Site Survey report to Congress.

\title{
SEPTEMBER 1976
}

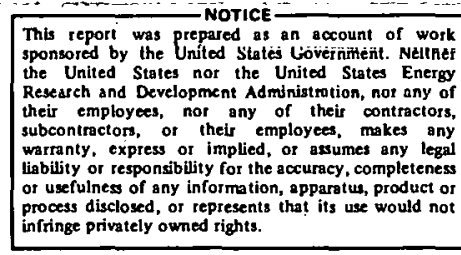

OAK RIDGE NATIONAL LABORATORY

nak Ridge, Tennessee 37830

operated by

UNION CARBIDE CORPORATION

for the

ENERGY RESEARCH AND DEVELOPMENT ADMINISTRATION 
THIS PAGE

\section{WAS INTENTIONALLY LEFT BLANK}


TABLE OF CONTENTS

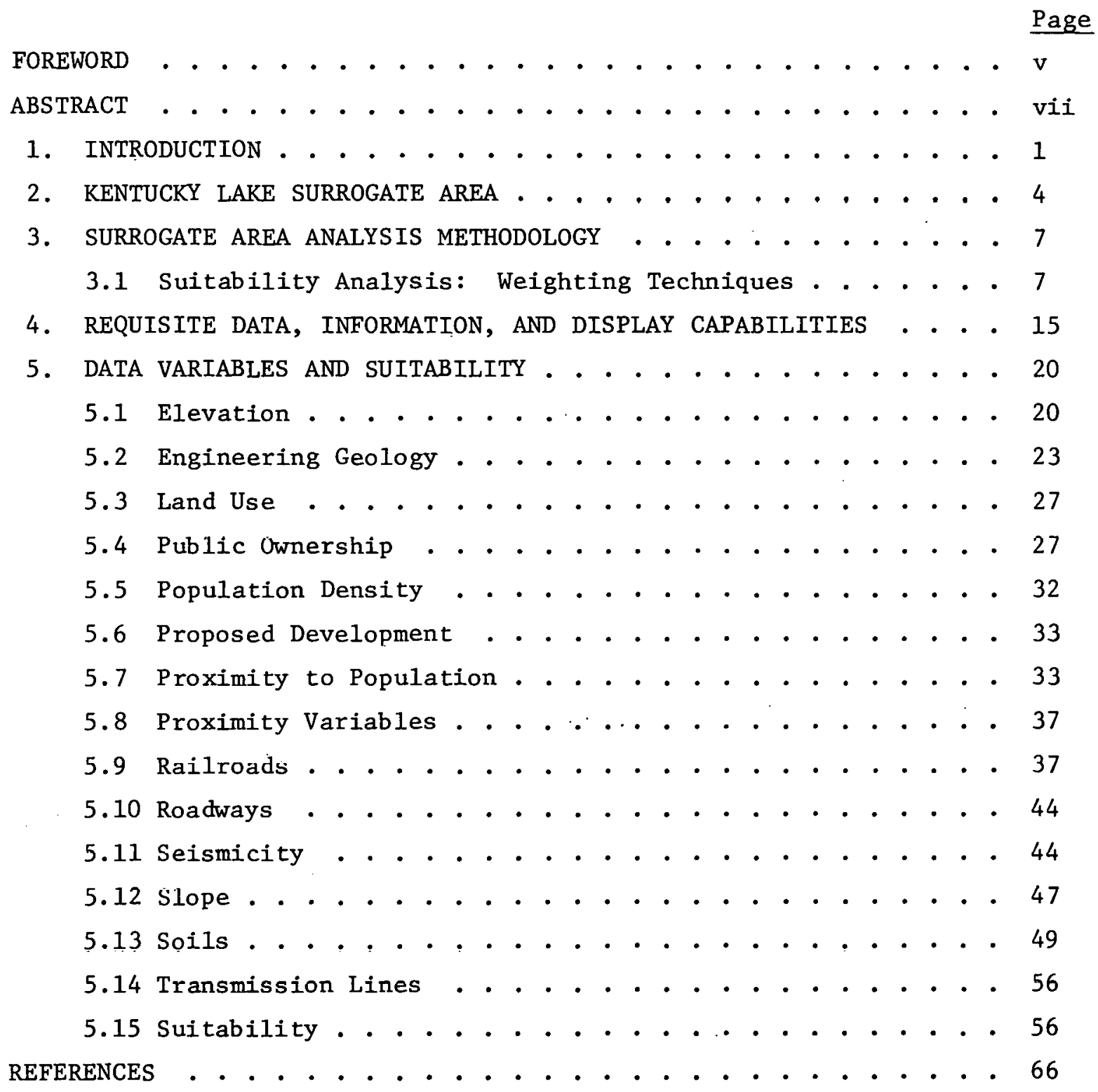


THIS PAGE

\section{WAS INTENTIONALLY LEFT BLANK}


FOREWORD

Section 207 of the Energy Reorganization Act of 1974 required the Nuclear Regulatory Commission to conduct a nuclear energy center site survey and report its findings to the Congress and the Council on Environmental Quality. The Survey included a general screening of the 48 contiguous States to identify large land areas that would be likely to contain sites potentially suitable for nuclear energy centers. It evaluated the technical and practical considerations involved in locating the production of electric power at a nuclear energy center and compared these considerations with those involved in producing an equivalent amount of power at dispersed sites.

One of the techniques utilized in the Survey was an analyoio of several "surrogate" sites. These specimen sites were selected to permit study of certain concepts and analysis of alternatives as they applied to a real, rather than hypothetlcal, location. Selection of a particular area for a surrogate site did not mean that it was a preferred or even well-suited site, but only that it represented particular site problems which were deemed worthy of study.

One of the surrogate sites selected for study was at Kentucky Lake, Tennessee. The Nuclear Regulatory Commission contracted with the Oak Ridge National Laboratory to undertake analysis of this site and to prepare reports on the various tasks when completed. This is one of a series of reports in the fulfillment of this assignment.

The complete report is composed of the following volumes:

Vol. I. Summary

Vol. II. Transmission of Power

Vol. III. Environmental Considerations

Vo1. IV. A Site Sclcction Methodulugy 
THIS PAGE

\section{WAS INTENTIONALLY LEFT BLANK}




\section{ABSTRACT}

A methodology has been developed for selecting suitable sites for development as nuclear energy centers. First, the forty-eight contiguous states were screened on the basis of four variables: (1) seismic stability; (2) distance from projected population centers; (3) adequate water supply; and (4) noninterference with scenic and reserved lands. After location of a surrogate area in north central Tennessee, further screening was performed using 22 variables to find a suitable 75-sq-mile surrogate site within this 1500-sq-mile area. A computer method for screening the surrogate area is presented, and the use of the data for the 22 variables is illustrated. 


\section{A SITE SELECTION METHODOLOGY}

\section{INTRODUCTION}

The purpose of this report is to discuss the method of assessing relative advantages and disadvantages of candidate sites within candidate regions and to illustrate an application of the procedure to a surrogate site in a surrogate region. The output is a comparison of relative benefits of various sites within a particular larger area. It is not a comparison of the larger areas themselves, that is, for example, an area in Tennessee vs an area in New Jersey.

Four variables were applied to the entire United States to arrive at a more realistic study area. "More realistic" refers both to the practicality of the study and to the potential of a site to support a nuclear energy center (NEC). The United States, then, was reduced as a study area to include only the areas that showed the most promise as eligible for NECs according to criteria of four variables - seismicity, population, water, and Federal and state lands. This "screening" of areas that were and were not likely to be capable of supporting NECs was accomplished by means of map overlays. Of the areas that were shown to have potential, three were selected as surrogate areas.

The phrase "surrogate area" is used to describe hypothetical areas within which suitable future sites for NECs might be expected to be found. Surrogate areas represent tracts of land that are about twenty times larger than surrogate sites. The areas are hypothetical in that they were chosen solely to serve the purposes of the NEC surrogate site and without consultation with organizations responsible for planning future generating capacity, without site visits, and without discussion with respective state or county officials, either public or private. The surrogate areas are not under consideration for the actual installation of an NEC.

Three areas were selected for study from the results of the coarse screening: Kentucky Lake in Tennessee, northern New York on the St. Lawrence River, and the New Jersey coast southeast of the Fort Dix Military Reservation (see Fig. 1). The varying qualities of the areas, 


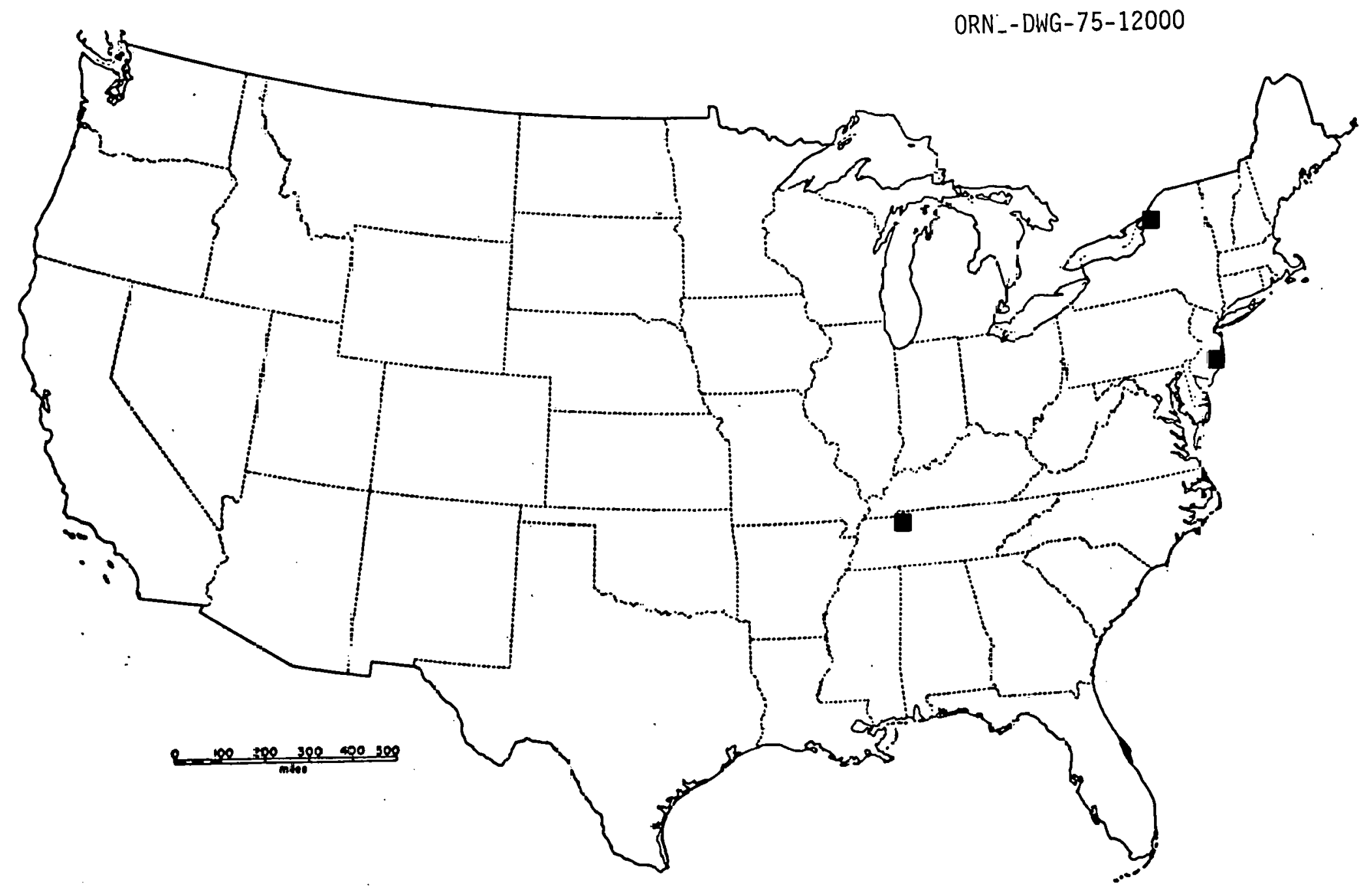

Fig. 1. Location of NEC surrogate site areas. 
shown in Table 1, offer distinctly different challenges. Because the charge of the study was to include the entire United States, consideration of a wide range of potential sites was necessary.

Table 1. Characteristics of NEC surrogate site areas

\begin{tabular}{lllll}
\hline Site & $\begin{array}{c}\text { Cooling } \\
\text { technology }\end{array}$ & $\begin{array}{c}\text { Type of } \\
\text { water source }\end{array}$ & Climate & $\begin{array}{l}\text { Transmission } \\
\text { configuration }\end{array}$ \\
$\begin{array}{l}\text { Kentucky Lake, } \\
\text { Tennessee }\end{array}$ & $\begin{array}{l}\text { Evaporative } \\
\text { towers }\end{array}$ & Lacustrine & $\begin{array}{l}\text { Humid } \\
\text { subtropical }\end{array}$ & Radial \\
New York & $\begin{array}{l}\text { Evaporative } \\
\text { towers }\end{array}$ & Lacustrine & $\begin{array}{l}\text { Humid } \\
\text { continental }\end{array}$ & $\begin{array}{l}\text { Remote concen- } \\
\text { trated load }\end{array}$ \\
New Jersey & $\begin{array}{l}\text { Evaporative } \\
\text { towers }\end{array}$ & Marine & $\begin{array}{l}\text { Humid } \\
\text { continental }\end{array}$ & $\begin{array}{l}\text { Concentrated } \\
\text { loads in 90 to } \\
150^{\circ} \text { segments }\end{array}$ \\
\hline
\end{tabular}

The remainder of this volume relates to (1) the eligibility of the Kentucky Lake surrogate area based on the four variables, (2) the method used to determine the relative suitability of cells within the surrogate areas, (3) a description of the display technique required for the analysis, and (4) a discussion of the variables used and their inclusion in the analysis. 


\section{KENTUCKY LAKE SURROGATE AREA}

This section is concerned primarily with the Kentucky Lake surrogate area and the determination of its potential to support an NEC. It is helpful to understand why the area survived the coarse screening exercise. The regional location of the Kentucky Lake surrogate area is shown in Fig. 2. The cities (load centers) surrounding the area graphically display the radial distribution pattern referred to in Table 1. The area itself, however, is sparsely populated. Nashville is the nearest SMSA, and Clarksville is the nearest municipality with more than 25,000 residents. Clarksville is about $7 \mathrm{mlles}$ from the study area, and therefore the area is not affected by the 5-mile excluded zone around the city.

Seismically, the area does not present severe difficulty for finding a site, but it is not as well suited as, for example, some areas of eastern Tennessee and the entire state of Louisiana. The Kentucky Lake surrogate area is located in the level 2 area of the map of "Areas of Relative Seismic Suitability for Nuclear Energy Centers," which was produced by the Nuclear Regulatory Commission and used as a measure of seismic suitability. This indicates that site-specific studies would have to be conducted to determine suitability.

The area is served by two sources of water - Kentucky Lake and the Cumberland River. Kentucky Lake on the Tennessee River runs from the northern to the southern border of the study region. The annual 20-year low flow of the Tennessee River at its outflow is $48,600 \mathrm{cfs}$, and 1 ts monthly 20-year low flow is about 23,600 cfs. Kentucky Lake, with its large surface area, provides onsite storage capacity. The Cumberland River enters the surrogate area from the east and exits through the north. It is smaller than the Tennessee River, with an annual 20-year flow of $18,600 \mathrm{cfs}$ at the outflow and a monthly 20-year low flow of 4000 cfs. If one assumes that $10 \%$ of the annual 20 -year low flow would be available as cooling water, both water sources can support multiple reactors. A 1200-MWe reactor consumes about $30 \mathrm{cfs}$ when generating at peak times (i.e., on a hot summer day, running $24 \mathrm{hr}$ ). However, $20 \mathrm{cfs}$ is a more realistic figure for average water consumption assuming a load factor of 65 to $70 \%$. 


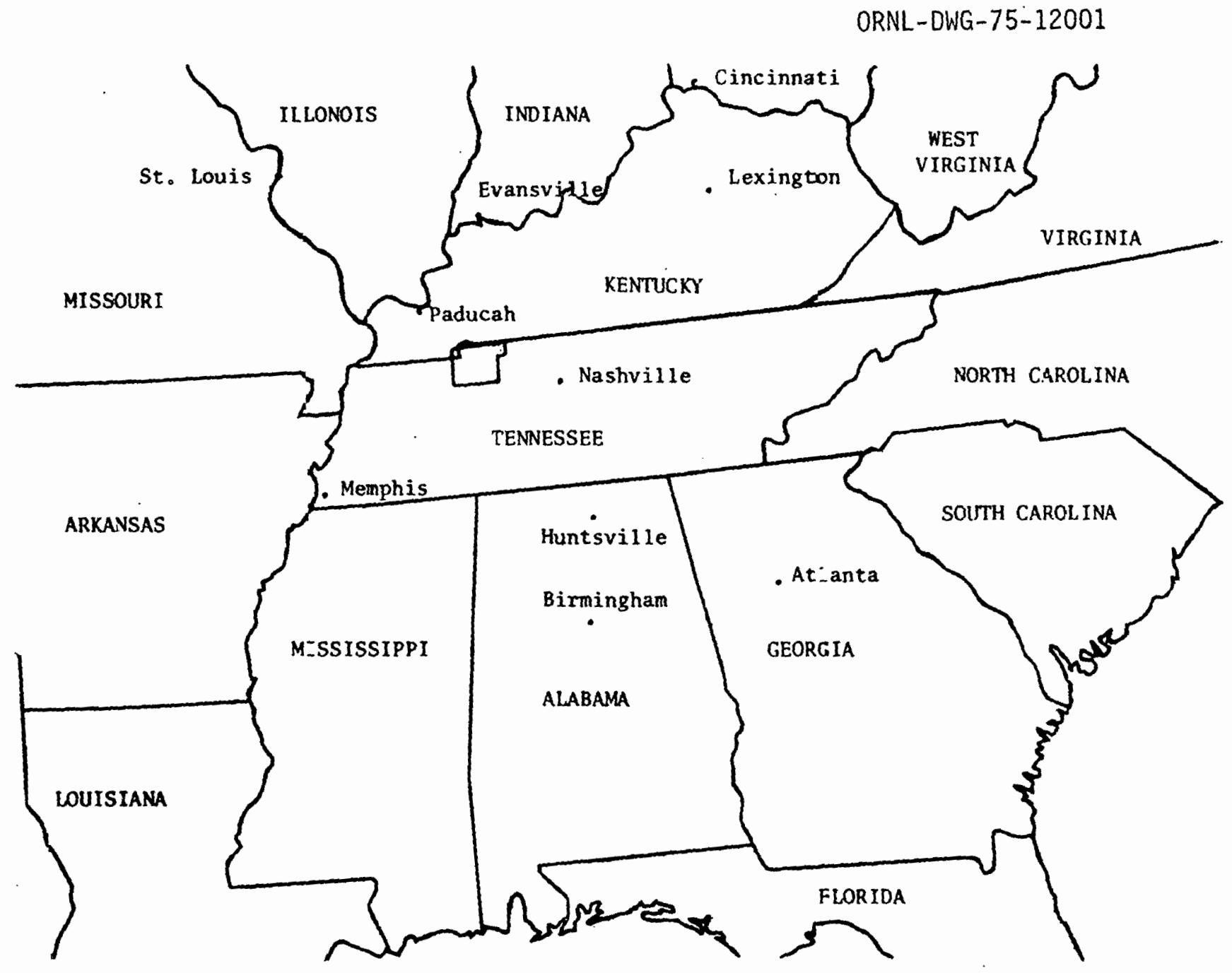

Fig. 2. Regional location of the Kentucky Lake surrogate area. Scale: 1:7,954,545. 
Finally, no land within or in the immediate proximity of the surrogate area has been excluded by the Energy Reorganization Act of 1974. ' The Land-Between-the-Lakes Recreation Area was not excluded because it is not a national park, forest, or monument. It was, however, weighted very negatively for its attractiveness as a potential NEC site in the analysis. The extension in the northeast corner of the surrogate area reflects the inclusion of Fort Campbell Military. Reservation. This was done to comply with Section 207(a)(3)(c) of the Energy Reorganization Act, which stated that the survey shall include consideration of lands already in Federal ownership. 


\section{SURROGATE AREA ANALYSIS METHODOLOGY}

The purpose of the siting method was to determine favorable surrogate sites within the larger Kentucky Lake surrogate area and to describe the area itself. It has been assumed that a 48,000-MWe NEC would occupy around $75 \mathrm{sq}$ miles. This figure represents the land area actually used for the reactors, cooling towers, and exclusion area, but excludes the land used for transmission corridors. The Kentucky Lake surrogate area was about $1300 \mathrm{sq}$ miles. The object of the method, then, was to find the "best" 75-sq-mile area (surrogate site) within the Kentucky Lake study area.

\subsection{Suitability Analysis: Weighting Techniques}

The problem at hand was the siting of an NEC technology package. Spatial information was broken down by data category and was stored within a two-dimensional cellular structure (see Sects. 4 and 5). A process was needed to relate cell data to the suitability of a cell to support an NEC quad unit. (An NEC quad unit is a group of four reactors, which served as the basic unit for building larger NECs.)

The NEC surrogate site identification methodology uses two sets of weighting factors. One set identified the relative importance of one data variable compared with another in making a siting decision. The importance values for the NEC technology package were arranged in a 1 x 22 matrix. The importance weights took values of one to five, where one was least important and five was most important. The importance matrix used in the analysis is reproduced in the first two columns of Table 2.* The other set of weights examined the compatibility of a specific data category (e.g., $2 \%$ slope) with the NEC technology sets. The compatibility values were arranged in a vector of data ( 1 × 65 matrix) as shown in

* The importance and compatibility values used in the Kentucky Lake area are for demonstration purposes only. They represent concensus of one panel of project participants. 
Table 2, Suitability criteria for NECs

\begin{tabular}{|c|c|c|c|}
\hline Variable & $\begin{array}{c}\text { Importance } \\
\text { values }\end{array}$ & Data categories & $\begin{array}{c}\text { Compatibility } \\
\text { values }\end{array}$ \\
\hline $\begin{array}{l}\text { Elevation, } \\
\text { ft above } \\
\text { sea level }\end{array}$ & 2 & $\begin{array}{l}350-449 \\
450-549 \\
550-674 \\
675+\end{array}$ & $\begin{array}{r}+1 \\
0 \\
-1 \\
-2\end{array}$ \\
\hline $\begin{array}{l}\text { Engineering } \\
\text { geology }\end{array}$ & 5 & See Table 3 & \\
\hline $\begin{array}{l}\text { Isand use } \\
\text { (prlimary) }\end{array}$ & 5 & $\begin{array}{l}\text { Urban } \\
\text { WaLer } \\
\text { Open } \\
\text { Forest }\end{array}$ & $\begin{array}{l}-3 \\
-3 \\
+2 \\
+1\end{array}$ \\
\hline $\begin{array}{l}\text { Land use } \\
\text { (secondary) }\end{array}$ & 4 & $\begin{array}{l}\text { Urban } \\
\text { Water } \\
\text { Open } \\
\text { Forest }\end{array}$ & $\begin{array}{r}-3 \\
0 \\
+2 \\
+1\end{array}$ \\
\hline $\begin{array}{l}\text { Land use } \\
\text { (tertiary) }\end{array}$ & 3 & $\begin{array}{l}\text { Urban } \\
\text { Water } \\
\text { Open } \\
\text { Forest }\end{array}$ & $\begin{array}{l}-3 \\
+1 \\
+2 \\
+1\end{array}$ \\
\hline $\begin{array}{l}\text { Ownership } \\
\text { (public) }\end{array}$ & 4 & $\begin{array}{l}\text { Military } \\
\text { TVA-other } \\
\text { TVA-recreational } \\
\text { Land-Between-the-Lakes } \\
\text { Fort Donnelson } \\
\text { Wildlife refuges } \\
\text { Public recreation }\end{array}$ & $\begin{array}{l}+2 \\
+2 \\
-2 \\
-3 \\
-3 \\
-3 \\
-2\end{array}$ \\
\hline $\begin{array}{l}\text { l'opulation } \\
\text { density, } \\
\text { pcrsons/sq } \\
\text { mile }\end{array}$ & 5 & $\begin{array}{l}U-30 \\
3 I-100 \\
101-300 \\
301-640 \\
640+\end{array}$ & $\begin{array}{r}+2 \\
+1 \\
0 \\
-1 \\
-2\end{array}$ \\
\hline $\begin{array}{l}\text { Proposed } \\
\text { development }\end{array}$ & 1 & $\begin{array}{l}\text { Industrial site } \\
\text { Road corridor }\end{array}$ & $\begin{array}{r}+2 \\
0\end{array}$ \\
\hline $\begin{array}{l}\text { Proximity to } \\
\text { population }\end{array}$ & 5 & $\begin{array}{l}0.022 \leq \operatorname{SPF}(30) \leq 0.042 \\
0.043 \leq \mathrm{SPF}(30) \leq 0.133\end{array}$ & $\begin{array}{l}+2 \\
+1\end{array}$ \\
\hline $\begin{array}{l}\text { Proximity to } \\
\text { railroads, } \\
\text { cells }\end{array}$ & 3 & $\begin{array}{c}0-2 \\
3-6 \\
7-10 \\
11+\end{array}$ & $\begin{array}{r}+2 \\
+1 \\
0 \\
-1\end{array}$ \\
\hline
\end{tabular}


Table 2 (Continued)

\begin{tabular}{|c|c|c|c|}
\hline Variable & $\begin{array}{l}\text { Importance } \\
\text { values }\end{array}$ & Data categories & $\begin{array}{c}\text { Compatibility } \\
\text { values }\end{array}$ \\
\hline $\begin{array}{l}\text { Proximity to } \\
\text { recreation } \\
\text { areas, cells }\end{array}$ & 4 & $\begin{array}{l}0-6 \\
7+\end{array}$ & $\begin{array}{r}-2 \\
0\end{array}$ \\
\hline $\begin{array}{l}\text { Proximity to } \\
\text { light-duty } \\
\text { roadways, } \\
\text { cells }\end{array}$ & 2 & $\begin{array}{l}0-2 \\
3-6 \\
7-10 \\
11+\end{array}$ & $\begin{array}{r}+2 \\
+1 \\
0 \\
-2\end{array}$ \\
\hline $\begin{array}{l}\text { Proximity to } \\
\text { medium-duty } \\
\text { roadways, } \\
\text { cells }\end{array}$ & 3 & $\begin{array}{l}0-2 \\
3-6 \\
7-10 \\
11+\end{array}$ & $\begin{array}{r}+2 \\
+1 \\
0 \\
-2\end{array}$ \\
\hline $\begin{array}{l}\text { Proximity to } \\
\text { transmission } \\
\text { lines, cells }\end{array}$ & 1 & $\begin{array}{c}0-2 \\
3-10 \\
10+\end{array}$ & $\begin{array}{r}+2 \\
+1 \\
0\end{array}$ \\
\hline $\begin{array}{l}\text { Proximity to } \\
\text { water, cells }\end{array}$ & 5 & $\begin{array}{c}0-2 \\
3-4 \\
5-7 \\
8-10 \\
11+\end{array}$ & $\begin{array}{r}+2 \\
+1 \\
0 \\
-1 \\
-2\end{array}$ \\
\hline Railroads & 3 & Presence in cell absence & $\begin{array}{r}+2 \\
0\end{array}$ \\
\hline Roadways & 3 & $\begin{array}{l}\text { Light-duty } \\
\text { Medium-duty } \\
\text { Light and medium }\end{array}$ & $\begin{array}{l}+2 \\
+1 \\
+1\end{array}$ \\
\hline $\begin{array}{l}\text { Seismicity, } \\
\% g\end{array}$ & 5 & $\begin{array}{l}0-1,0 \\
11-20 \\
21-30 \\
31-40 \\
40+\end{array}$ & $\begin{array}{r}+2 \\
+1 \\
0 \\
-1 \\
-2\end{array}$ \\
\hline $\begin{array}{l}\text { Slope } \\
\text { (primary), } \\
\%\end{array}$ & 4 & $\begin{array}{l}0-8 \\
8-16 \\
16+\end{array}$ & $\begin{array}{l}+2 \\
+1 \\
=3\end{array}$ \\
\hline $\begin{array}{l}\text { Slope } \\
\text { (secondary), } \\
\%\end{array}$ & 3 & $\begin{array}{l}0-8 \\
8-16 \\
16+\end{array}$ & $\begin{array}{l}+2 \\
+1 \\
-3\end{array}$ \\
\hline
\end{tabular}


Table 2 (Continued)

\begin{tabular}{lccc}
\hline \multicolumn{1}{c}{ Variable } & $\begin{array}{c}\text { Importance } \\
\text { values }\end{array}$ & Data categories & $\begin{array}{c}\text { Compatibility } \\
\text { values }\end{array}$ \\
\hline Soils & 5 & $\begin{array}{l}\text { See Tables } \\
4,10, \text { and } 11\end{array}$ & \\
\hline $\begin{array}{l}\text { Transmission } \\
\text { lines }\end{array}$ & 2 & $\begin{array}{l}\text { Presence in cell } \\
\text { Absence in cell }\end{array}$ & +1 \\
\hline
\end{tabular}

Table 2. 'l'he compatibilley scores took values of +2 to -2 (as illustrated in Tables 3 and 4 ), where +2 was most compatible and -2 was least compatible. A -3 indicates either an extreme fncompatibility or exclusion (e.g., if a cell consists of water).

Table 3. Compatibility values of engineering geology

\begin{tabular}{|c|c|c|c|c|c|}
\hline \multirow{2}{*}{ Class 1ithology ${ }^{\alpha}$} & \multicolumn{5}{|c|}{ Class structural attitude ${ }^{b}$} \\
\hline & $\begin{array}{l}\text { Faulted } \\
(4)\end{array}$ & $\begin{array}{r}\text { Tightly } \\
\text { (3) }\end{array}$ & folded & $\begin{array}{c}\text { Domed, arched } \\
\text { (2) }\end{array}$ & $\begin{array}{c}\text { Flat-lying } \\
\text { (1) }\end{array}$ \\
\hline $\begin{array}{l}\text { Coastal plain } \\
\text { sediments }(7)\end{array}$ & -2 & -2 & . & -1 & 0 \\
\hline $\begin{array}{l}\text { Carbonate } \\
\text { rocks (4) }\end{array}$ & -2 & -2 & & -1 & 0 \\
\hline $\begin{array}{l}\text { Shale, slate, } \\
\text { phyllite, and } \\
\text { schiot (3) }\end{array}$ & -2 & -1 & & 0 & +1 \\
\hline $\begin{array}{l}\text { Interbedded } \\
\text { rocks (2) }\end{array}$ & -1 & -1 & & 0 & +1 \\
\hline $\begin{array}{l}\text { Metamorphic } \\
\text { rocks (5) }\end{array}$ & 0 & 0 & & +1 & +1 \\
\hline $\begin{array}{l}\text { Igneous } \\
\text { rocks (6) }\end{array}$ & 0 & 0 & & +1 & +2 \\
\hline Sandstone (1) & 0 & +1 & & +2 & +2 \\
\hline
\end{tabular}


Table 4. Compatibility values of soils

\begin{tabular}{|c|c|c|c|c|c|}
\hline \multirow{2}{*}{ Class type $e^{a}$} & \multicolumn{5}{|c|}{ Class thickness ${ }^{b}$ (ft) } \\
\hline & $\begin{array}{l}>100 \\
(5)\end{array}$ & $\begin{array}{l}50-100 \\
(3)\end{array}$ & $\begin{array}{l}0-100 \\
(4)\end{array}$ & $\begin{array}{l}0-50 \\
(2)\end{array}$ & $\begin{array}{l}>10 \\
(1)\end{array}$ \\
\hline $\begin{array}{l}\text { Swamps, } \\
\text { marshes, etc. (5) }\end{array}$ & -2 & -2 & -2 & -1 & 0 \\
\hline $\begin{array}{l}\text { Glaciolacustrine, } \\
\text { glaciomarine ( } 8)\end{array}$ & -2 & -2 & -2 & $\therefore$ & 0 \\
\hline $\begin{array}{l}\text { Recent } \\
\text { alluvium (4) }\end{array}$ & -2 & -2 & -1 & 0 & +1 \\
\hline $\begin{array}{l}\text { Continental } \\
\text { deposits (1) }\end{array}$ & -2 & -2 & -1 & 0 & +1 \\
\hline $\begin{array}{l}\text { Marine silt } \\
\text { and clay (3) }\end{array}$ & -2 & -1 & -1 & 0 & 0 \\
\hline Residual soil (9) & -2 & -1 & -1 & 0 & 0 \\
\hline Glaciofluvial (6) & -1 & -1 & 0 & 0 & +1 \\
\hline $\begin{array}{l}\text { Marine sand } \\
\text { and gravel (2) }\end{array}$ & -1 & 0 & 0 & $\therefore+1$ & +1 \\
\hline Glacial till (7) & 0 & 0 & +1 & +1 & 0 \\
\hline
\end{tabular}

Numbers in parentheses come from first number of soil coding. $b_{\text {Numbers }}$ in parentheses come from second number of soil coding.

The compatibility and importance matrices were combined to yield an index of suitability that related cell characteristics to suitability for an NEC. This cell suitability index (CSI) was determined by the equation,

$$
\operatorname{CSI} I_{c}=\frac{\sum_{v=1}^{\mathrm{x}} \mathrm{s}_{\mathrm{cv}} \mathrm{I}_{\mathrm{v}}}{2 \sum_{\mathrm{v}=1}^{\mathrm{s}} \mathrm{I}_{\mathrm{v}}} \text {, }
$$

where

$\mathrm{S}_{\mathrm{cv}}=$ the compatibility score for the cth cell for the vth variable, $I_{v}=$ the importance weight for the vth variable, 
$s=$ the number of variables being considered in the analysis,

$x_{v}=$ the maximum number of values the vth variable takes $\left(x_{v} \leq s\right)$.

The summation of the importance factors is multiplied by +2 because the denominator represents the maximum possible score a cell could receive under the most favorable conditions. This procedure facilitates comparison. Tables 5 and 6 are examples of cell suitability index calculations. The cell under consideration in Table 5 is hypothetically located in the Land-Between-the-Lakes Recreation Area, as is indicated by the ownership variable. Public ownership has an importance var1able of 4, Ludicating relatively high importance as compared with the other variables. However, as stated earlier, the Land-Between-the-Lakes Recreation Area was considered to be highly incompatible with the construction of an NEC. Therefore, the product of the importance and compatibility evaluations 1s a -12. This factor and some other poor qualities of the cell (such as seismicity and primary slope) yield a rather low score for the cell suitability index. The cell for which the index is calculated in Table 6, however, is more advantageously situated, as is indicated by the higher cell suitability index (0.28). Although this cell does contain some negative characteristics such as relatively steep primary slope, they are outweighed by positive qualities such as low population density, distance from a population center, and nearness to water.

Because the suitability score is unitless, it is susceptible to misinterpretation. The CSI is a quantification of an intanglble but should not lure the user into a false sense of security. Site suitability is largely determined by social values (e.g.,. deslre to protect endangered species). Because perceptions of these values vary, the method was set up to accept quick changes in weights. Therefore, while examining a set of resultant scores one should remain cugnizant of the positions of those who designated the welghts as well as the cundlions under which they operated.

Likewise, the form and makeup of the data should also be known. Resolution of the data and its relation to the location of the candidate region bear on the meaning of the CSI. Also, the number of variables included and their relative importance influence the comparative suitability of candidate sites. 
Table 5. Cell sultability index calculation: example $1^{a}$

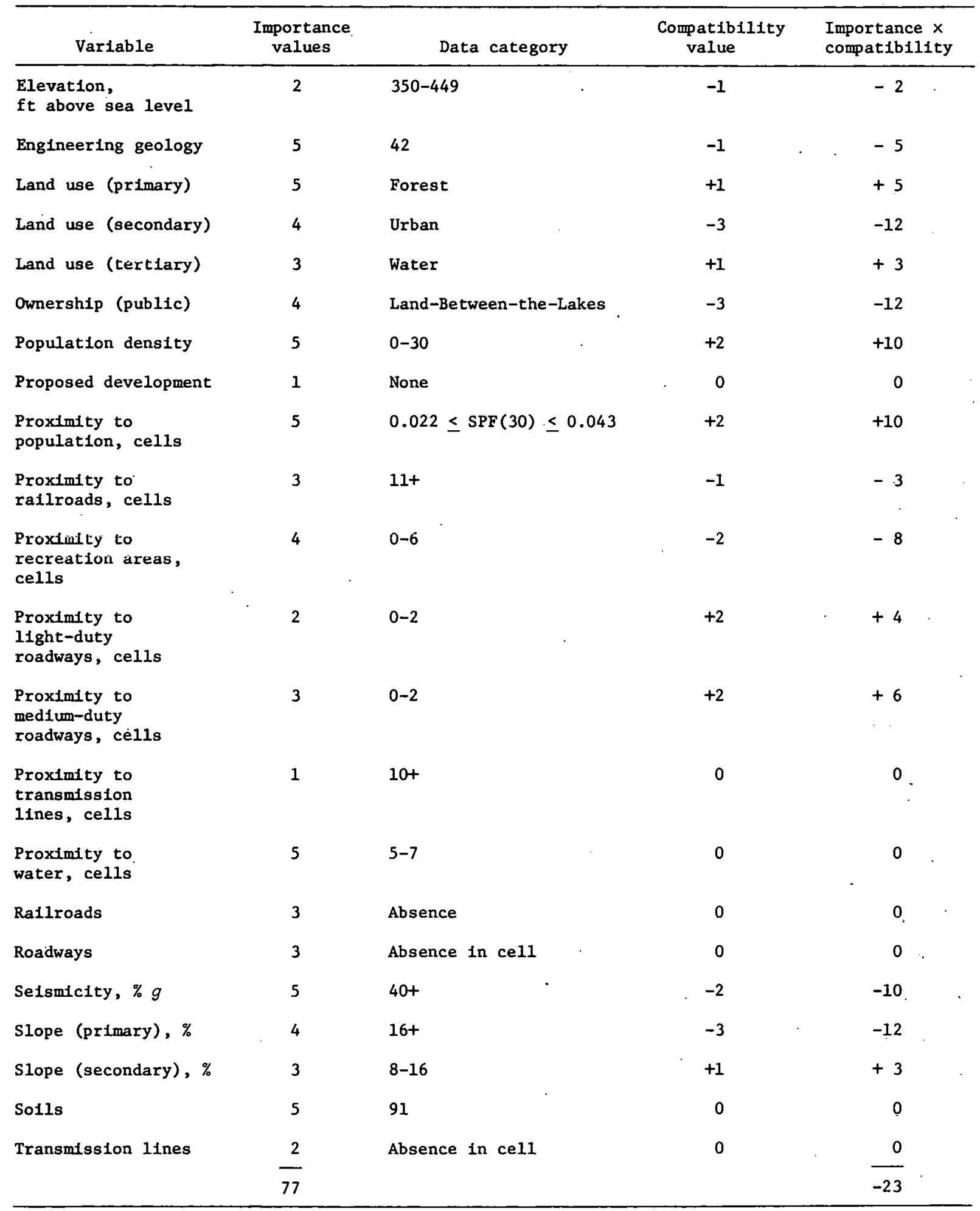

$a_{C S I_{c}}=\frac{\sum_{v=1}^{x} S_{c v} I_{v}}{2\left(\begin{array}{cc}s & I_{v} \\ v=1\end{array}\right)}=\frac{-2.3}{2(77)}=-0.15$. 
Table 6. Cell sultability index calculation: example $2^{a}$

\begin{tabular}{|c|c|c|c|c|}
\hline Variable & $\begin{array}{l}\text { Importance } \\
\text { values }\end{array}$ & Data category & $\begin{array}{l}\text { Compatibility } \\
\text { value }\end{array}$ & $\begin{array}{l}\text { Importance } x \\
\text { compatibility }\end{array}$ \\
\hline $\begin{array}{l}\text { Elevation, } \\
\text { ft above sea level }\end{array}$ & 2 & $350-449$ & +1 & +2 \\
\hline Engineering geology & 5 & 42 & -1 & -5 \\
\hline Land use (primary) & 5 & Forest & +1 & +5 \\
\hline Land use (secondary) & 4 & Water & 0 & 0 \\
\hline Land use (tertiary) & 3 & Open & +2 & +6 \\
\hline Ownership (public) & 4 & None & 0 & 0 \\
\hline Population density & 5 & $0-30$ & +2 & 110 \\
\hline Proposed development & 1 & None & 0 & 0 \\
\hline $\begin{array}{l}\text { Proximity to } \\
\text { population, cells }\end{array}$ & 5 & $0.022 \leq \operatorname{sPF}(30) \leq 0.133$ & +2 & +10 \\
\hline $\begin{array}{l}\text { Proximity to } \\
\text { railroads, cells }\end{array}$ & 3 & $0-2$ & +2 & +6 \\
\hline $\begin{array}{l}\text { Proximity to } \\
\text { recreation areas, } \\
\text { cells }\end{array}$ & 4 & $7+$ & 0 & 0 \\
\hline $\begin{array}{l}\text { Proximity to } \\
\text { light-duty } \\
\text { roadways, cells }\end{array}$ & 2 & $0-2$ & +2 & +4 \\
\hline $\begin{array}{l}\text { Proximity to } \\
\text { medium-duty } \\
\text { roadways, cells }\end{array}$ & 3 & $11+$ & -2 & -6 \\
\hline $\begin{array}{l}\text { Proximity to } \\
\text { transmission } \\
\text { lines, cells }\end{array}$ & 1 & $10+$ & 0 & 0 \\
\hline $\begin{array}{l}\text { Proximity to } \\
\text { water, cells }\end{array}$ & 5 & $0-2$ & +2 & +10 \\
\hline Kailiroade & 3 & Promentile lin tell & +2 & +6 \\
\hline nondwayo & 3 & I.tght $=$ Anty & +2 & +6 \\
\hline Seismicity, $\% g$ & 5 & $31-40^{\circ}$ & -1 & -5 \\
\hline Slope (primary), \% & 4 & $16+$ & -3 & -12 \\
\hline Slope (secondary), \% & 3 & $0-8$ & +2 & +6 \\
\hline Solls & 5 & 91 & 0 & 0 \\
\hline Transmission lines & $\frac{2}{77}$ & Absence in cell & 0 & $\frac{0}{+43}$ \\
\hline
\end{tabular}

$a_{\mathrm{CSI}_{\mathrm{c}}}=\frac{\sum_{\sum_{\mathrm{v}}^{\mathrm{v}}}^{\mathrm{v}} \mathrm{s}_{\mathrm{cv}} \mathrm{I}_{\mathrm{v}}}{2\left(\begin{array}{cc}\mathrm{s} & \mathrm{I} \\ \mathrm{v}=1 & \mathrm{v}\end{array}\right)}=\frac{43}{2(77)}=0.28$ 
4. REQUISITE DATA, INFORMATION, AND DISPLAY CAPABILITIES

The worth of any data base lies in its ability to provide needed input into problem-solving algorithms and analysis techniques. Thus, goal and problem definition generally must precede data acquisition. This becomes evident in light of cost considerations in addition to making certain that the data system will facilitate the resolution of the problems at hand. For the NEC surrogate site, the problem was fairly. well defined: to identify areas in which nuclear energy centers could be accommodated in terms of resource requirements and systemic impacts. With the specific problem in mind, a list of data items needed to make NEC siting decisions was generated.' In the interests of time and past experience, the list used in the NRC-Maryland Regional Siting Factors Study ${ }^{2}$ was modified for this purpose.

The mechan1sm used for displaying the data is also of critical importance, especially in a process designed to aid planners and decisionmakers. Two sets 'of display techniques were used: extant cartographic display capabilities generated by the ORNL/NSF-RESA Program ${ }^{3}$ and capabilities developed for the NRC-Maryland Regional Siting Factors Study. ${ }^{2}$ The principal display mechanism, discussed later in: the report, was a computer-mapping routine that used a line printer over-printing technique. This routine has the capability of outputting single-variable or multivariable index values in 20 shades of grey. Legends are given at the bottom of each map and relate grey-tone-symbols to data categories. Frequency of occurrence (i:e., number of cells in a category) and percentage of total cells in each category are also given in the legend.

Tables 7 and 8 are presented as overviews of the single variable evaluations of the entire Kentucky Lake area. Table 7 is a tabulation of the percentages of the Kentucky Lake area that are in various data categories of each variable: Table 8 provides a key to the data categories. Table 7 is presented to give the reader a quick profile of the entire area. without examining the computer graphics that follow. The manner by which this profiling capability can be useful in determining the overall suitab1llty of blocks of cells will be shown later. 
Table 7. Profile for site containing 4725 cells with rows 46 through 105 and columns 31 through 1.20

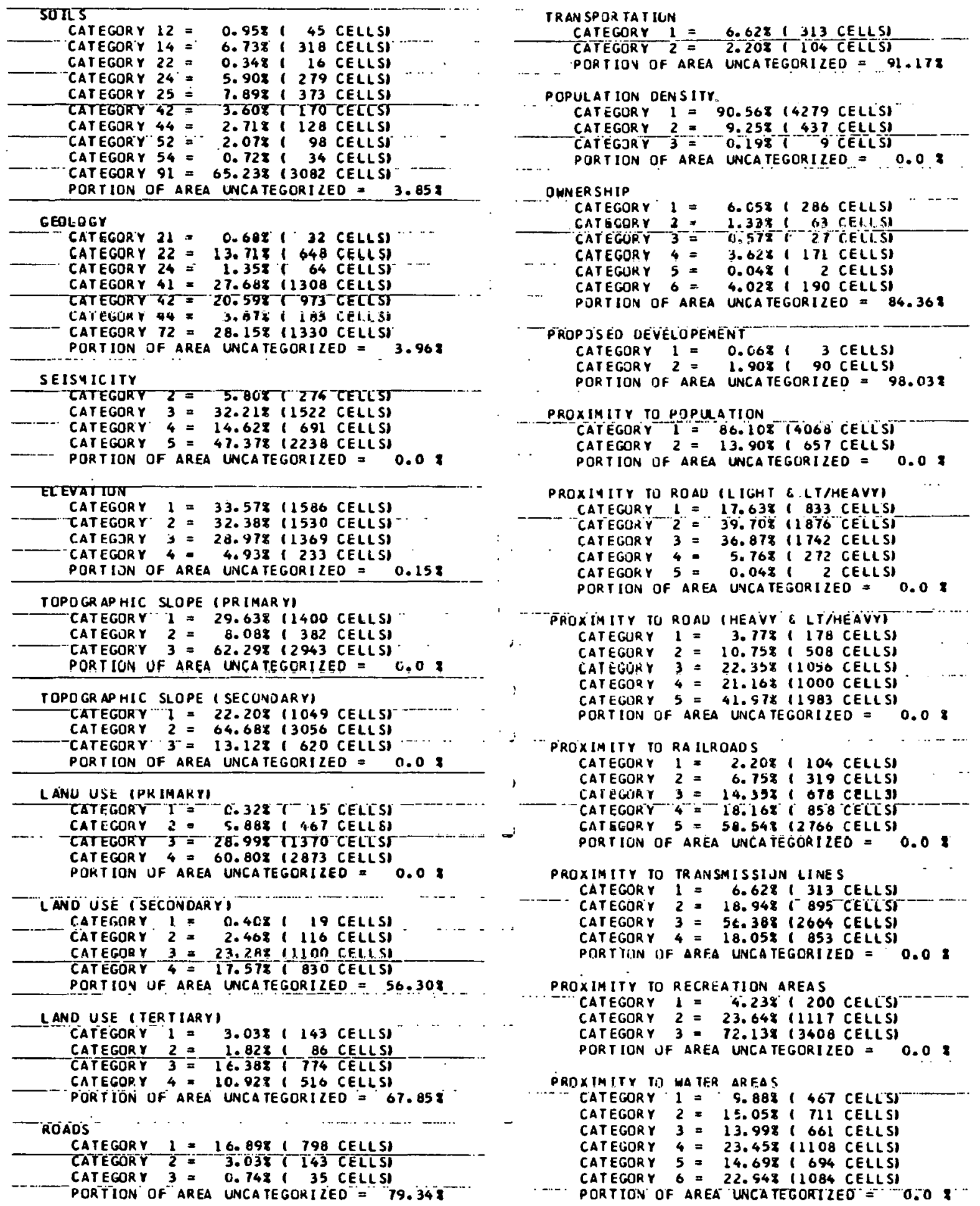


Table 8. Category definitions

\begin{tabular}{|c|c|c|c|c|c|c|}
\hline & \multirow{2}{*}{ Soils: class type } & \multicolumn{5}{|c|}{ Class thickness ( $f t)$} \\
\hline & & $\begin{array}{l}<10 \\
(1)\end{array}$ & $\begin{array}{l}0-50 \\
(2)\end{array}$ & $\begin{array}{c}0-100 \\
(3)\end{array}$ & $\begin{array}{c}50-100 \\
(4)\end{array}$ & $\begin{array}{l}>100 \\
(5)\end{array}$ \\
\hline 1. & Continental deposits & 11 & 12 & 13 & 14 & 15 \\
\hline 2 . & $\begin{array}{l}\text { Marine sand and } \\
\text { gravel }\end{array}$ & 21 & 22 & 23 & 24 & 25 \\
\hline 3. & Marine silt and clay & 31 & 32 & 33 & 34 & 35 \\
\hline 4 . & Recent alluvium & 41 & 42 & 43 & 44 & 45 \\
\hline 5 . & Swamps, marsh, etc. & 51 & 52 & 53 & 54 & 55 \\
\hline 6 . & Glaciofluvial & 61 & 62 & 63 & 64 & 65 \\
\hline 7. & Glacial till & 71 & 72 & 73 & 74 & 76 \\
\hline 8 . & $\begin{array}{l}\text { Glaciolacus trine, } \\
\text { glaciomarine }\end{array}$ & 81 & 82 & 83 & 84 & 85 \\
\hline 9. & Residual soil & 91 & 92 & 93 & 94 & 95 \\
\hline
\end{tabular}

\begin{tabular}{lcccc} 
& \multicolumn{3}{c}{ Class structural attitude } \\
\cline { 2 - 5 } Geology: class lithology & $\begin{array}{c}\text { Flat- } \\
\text { lying } \\
(1)\end{array}$ & $\begin{array}{c}\text { Domed, } \\
\text { arched } \\
(2)\end{array}$ & $\begin{array}{c}\text { Tightly } \\
\text { folded } \\
(3)\end{array}$ & $\begin{array}{c}\text { Faulted } \\
(4)\end{array}$ \\
\hline 1. Sandstone & 11 & 12 & 13 & 14 \\
2. Interbedded rocks & 21 & 22 & 23 & 24 \\
3. Shale, slate, & 31 & 32 & 33 & 34 \\
4. Carbonate rocks & 41 & 42 & 43 & 44 \\
5. Metamorphic rocks & 51 & 52 & 53 & 54 \\
6. Igneous rocks & 61 & 62 & 63 & 64 \\
7. Coastal plain sediments & 71 & 72 & 73 & 74 \\
\hline
\end{tabular}

Seismicity, \%g Topographic slope (primary), $\%$

\begin{tabular}{|c|c|}
\hline 1. $0-10$ & 1. $0-8$ \\
\hline 2. $11-20$ & 2. $9-16$ \\
\hline $\begin{array}{ll}\text { 3. } & 21-30 \\
\text { 4. } & 31-40\end{array}$ & $>16$ \\
\hline
\end{tabular}

Elevation, ft Topographic slope (secondary), $\%$

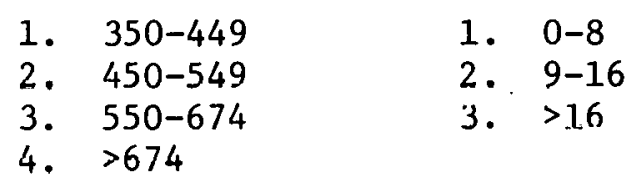


Table 8 (Continued)

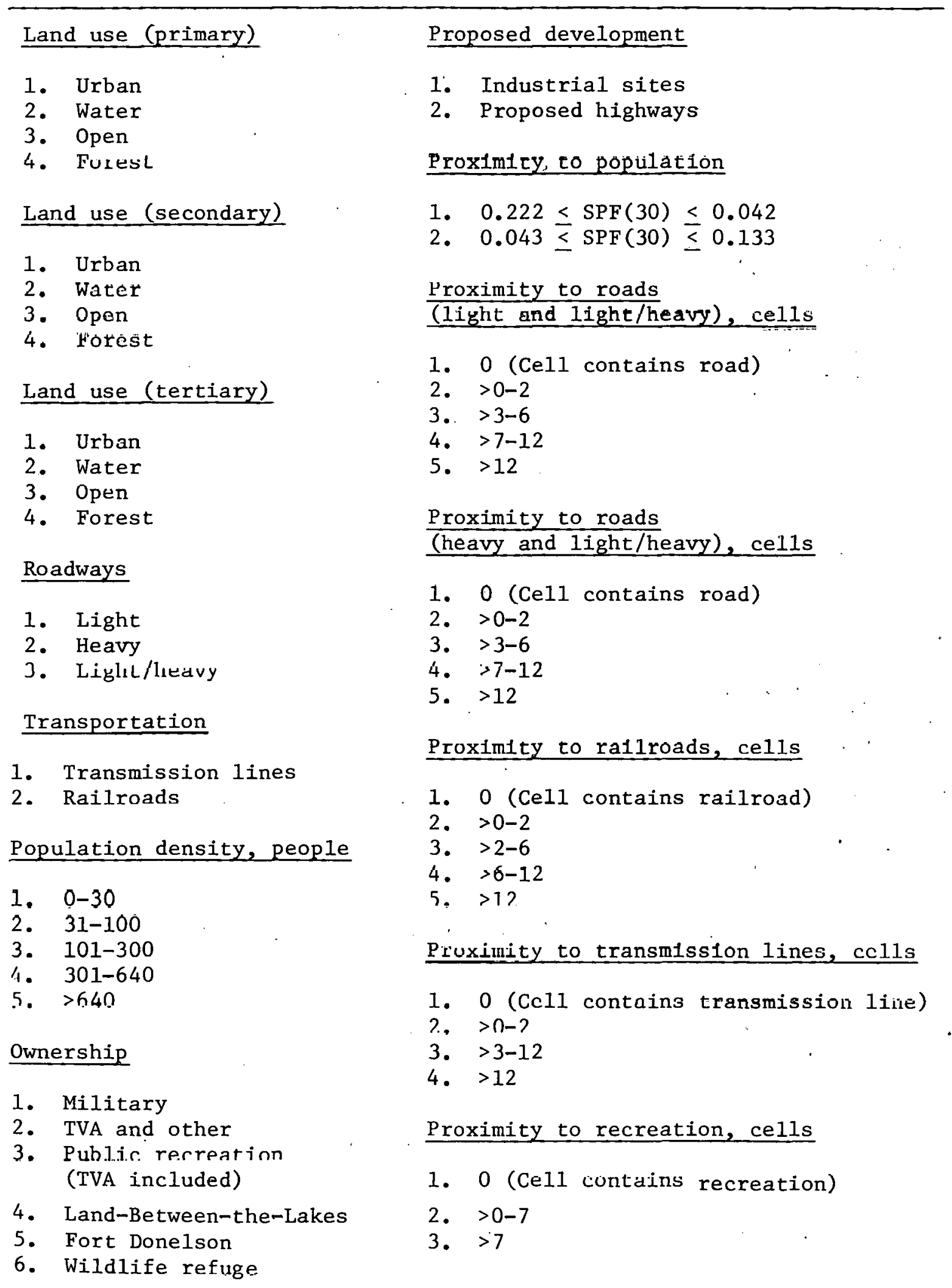


Table 8 (Continued)

Proximity to water, cells

1. 0 (Ce1l contains water)

2. $>0-2$

3. $>3-4$

4. $>5-8$

5. $>9-12$

6. $>12$ 


\section{DATA VARIABLES AND SUITABILITY}

Information was converted from map to digital form by manual digitization, semi-automated digitization, and calculation. The U.S. Geological Survey (USGS) 7.5-min topographic series maps used are shown in Fig. 3. Information was coded on the basis of 170-acre cells. The 170-acre cell unit was used to correspond to the size of one quad unit (including reactors and cooling towers). Because an analysis with a 170-acre resolution may not consider necessary information in sufficient detail (especially for particular variables such as slope), primary, secondary, and tertiary categories were used for some variables. As will be seen in the discussion of the individual variables, this classification expanded the initial data categories on the basis of the characteristic of the cell. Although this level of analysis is intended to be used as a finer indicator than the coarse screening, it still remains rather gross. The land area required for exclusion and limited use zones is not included in the 170-acre cells. Each cell corresponds to an area of approximately 30 " latitude $x$ 30" longitude. The information that is stored on magnetic tape for every 170-acre cell is described in the following sections.

\subsection{Elevation}

Elevation was digitized from the USGS 7.5-min topographic map series . Centroid elevations (heights above sea level) for the 170-acre cells are displayed in Fig. 4. Local relief (here defined as the difference between the maximum and minimum centroid elevation within the surrogate area) can provide useful information, for example, pumping requirements for water. The Kentucky Lake surrogate area contains a local relief of about $325 \mathrm{ft}$, with the lake surface at its lowest elevation. The western half of the area and the areas adjacent to the river are low-1ying. TVA sources indicate that the lake rarely fluctuates greater than $3 \mathrm{ft}$ in height (not above $353 \mathrm{ft}$ above sea level). The map does not indicate the areas falling strictly in this range, but very little of the shoreland appears to be subject to flooding because of the rapid increase in elevation in the land adjacent to the lake. 


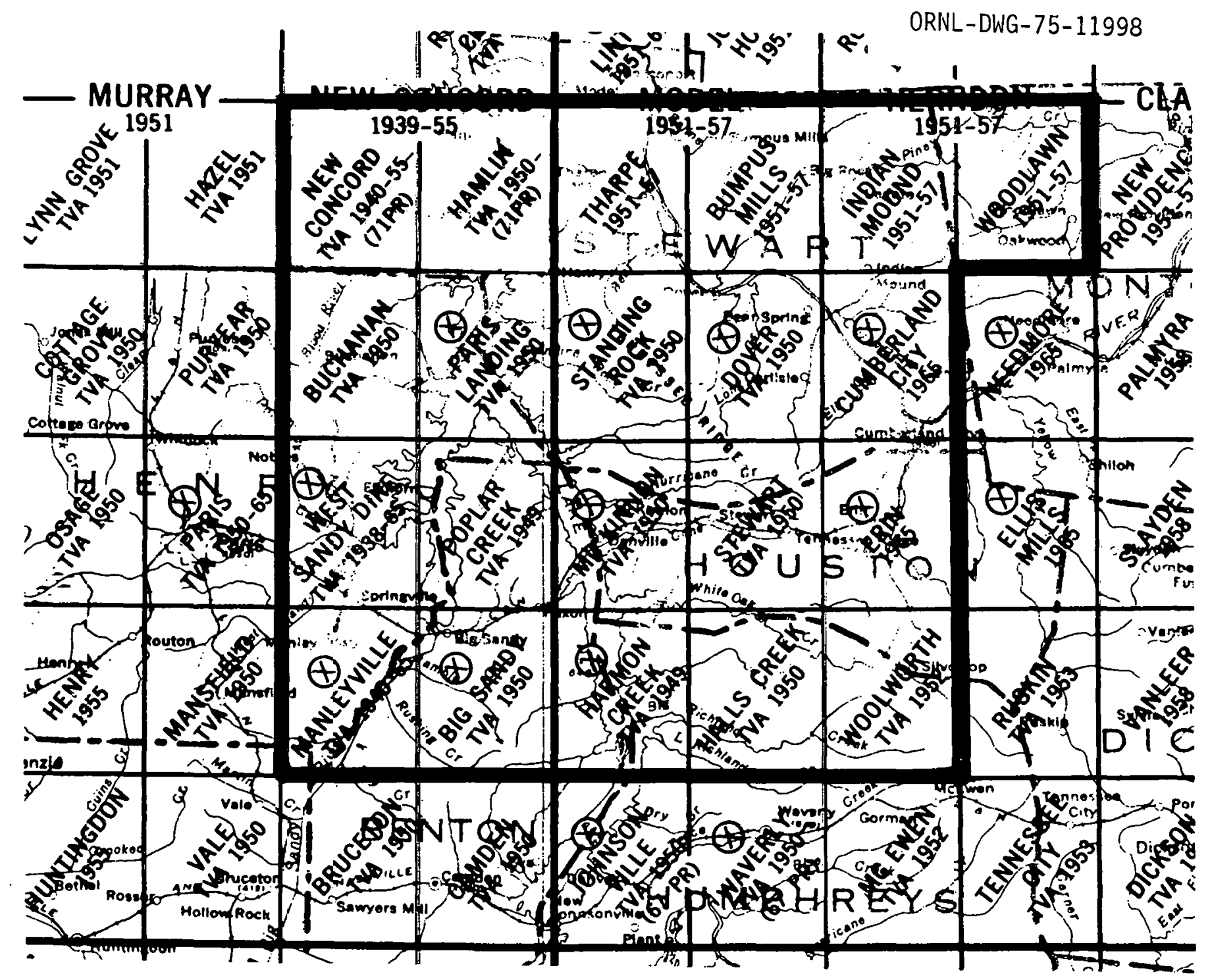

Fig. 3. USGS topographic cuadrangles in Kentioky Lake surrogate area. Scale: $=$ :552, 100 . 


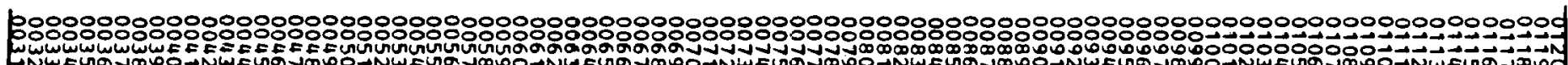

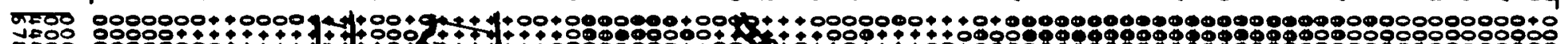

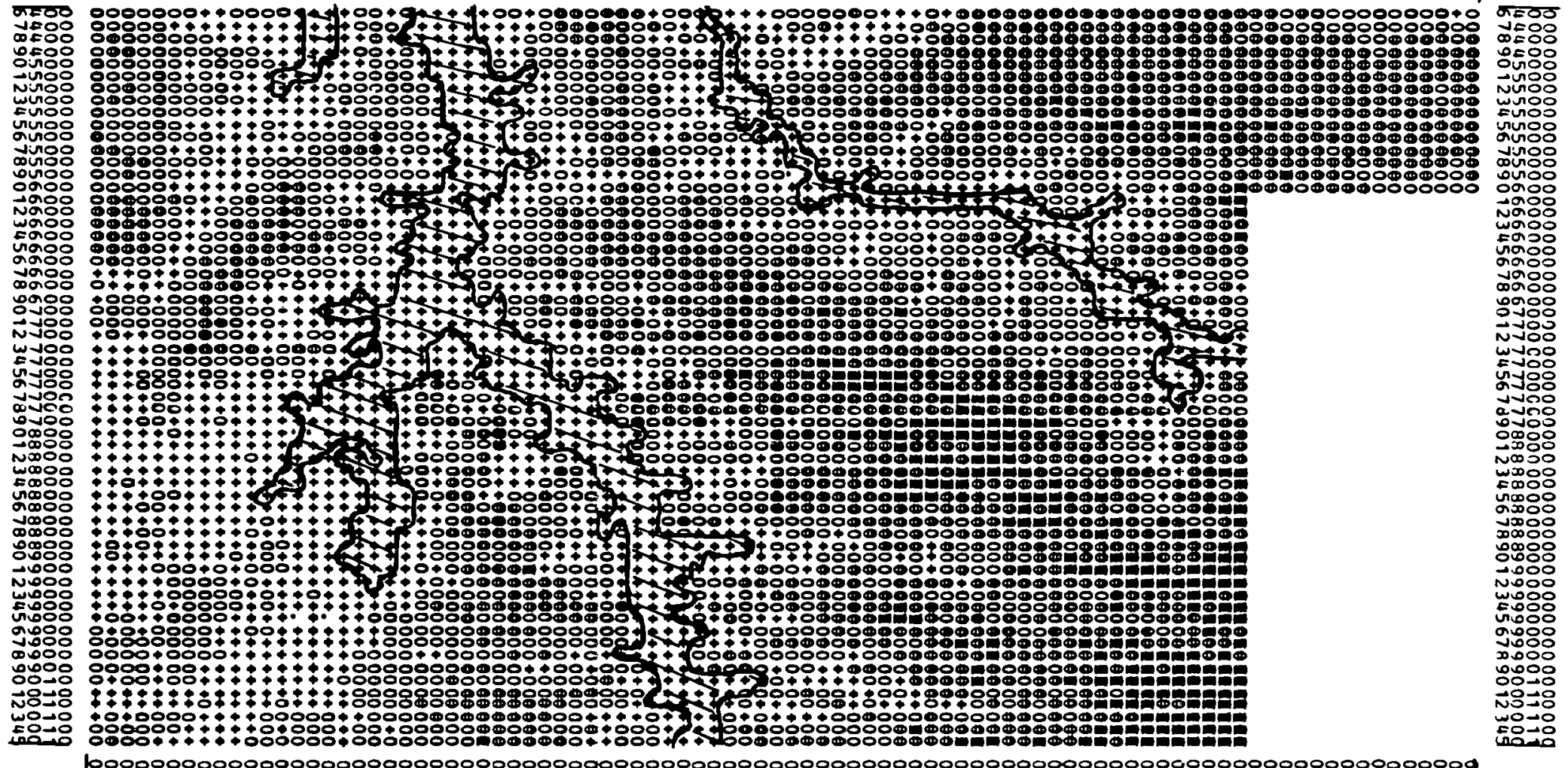
|

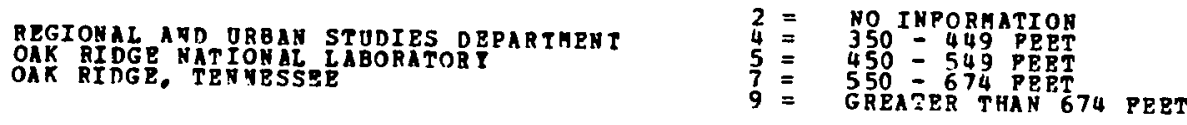

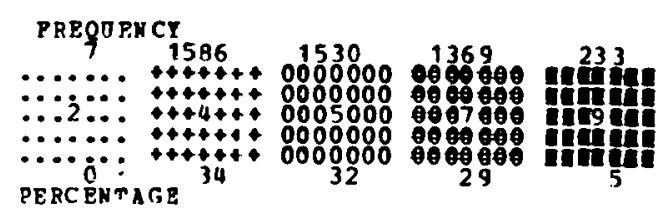

Fig. 4. Kentucky Lake NEC surrogate area: elevatioa. Scale: 1:560,000 


\subsection{Engineering Geology}

Bedrock geology was classified by two numbers, the first giving the bedrock lithology and the second giving the structural attitude (see Tables 9 and 10). Primary and secondary bedrock were distinguished and classified separately. The lithology classifications take into account all the major types of sedimentary rocks and interbedded sedimentary deposits of various types, as well as igneous and metamorphic rocks. Two additional categories include all other possible bedrock conditions. Unconsolidated Coastal Plain sediments, which are the only available founding materials over large areas of the Atlantic and Gulf Coastal Plains are included in a separate category and are considered to be a type of bedrock. In general, the classes are formed to denote the mechanical character of the rock, such as bedding, fissility, or the properties it is likely to assume in relation to its structural attitude. Thus, shale, slate, phyllite, and schist are grouped together as rocks with a pervasive, closely spaced fissility, and marbles and limestones are grouped as rocks that may develop subterranean caverns.

The structural attitude of the bedrock is divided into four classes. The first class includes areas that are flat-lying or without apparent structure. The second class includes areas that are domed, arched, warped, or flexed. Tightly folded and megascopically faulted rocks make up the two remaining classes. Because of the complexity of structure introduced, tightly folded rocks can be considered a negative cost factor. At the very least, an evaluative program would be required to satisfy regulatory requirements. If negative, the findings could result in increased design costs or possibly abandonment of the site.

A map of lithology for the Kentucky Lake study area is contained in Fig. 5. The eastern half of the surrogate area is characterized by carbonate rocks, and the western third by Coastal Plain sediments. A map of structural attitude is contained in Fig. 6. The eastern third of the region is flat-lying, whereas the western two-thirds is domed, arched, flexed, warped, or openly folded. A small area (about 5\%) in the east central portion of the region is megascopically faulted. Both figures show right-angle boundaries, which resulted from an error in collection of data from the field. The error was not correctable during this study. 
Table 9. Classification of lithology

\begin{tabular}{|c|c|c|}
\hline Class number ${ }^{\alpha}$ & Class name & Description \\
\hline 1 & Sands tone & $\begin{array}{l}\text { Siliceous and calcareous ortho- } \\
\text { quartzite and protoquartzite. }\end{array}$ \\
\hline 2 & Interbedded rocks & $\begin{array}{l}\text { Interbedded sandstone, lime- } \\
\text { stones, cherts, and shales. }\end{array}$ \\
\hline 3 & Fissile rocks & $\begin{array}{l}\text { Shale, slate, phyllite, and } \\
\text { schist. }\end{array}$ \\
\hline 4 & Carbonate rocks & $\begin{array}{l}\text { Limestone, dolomite, and calci- } \\
\text { tic and dolomitic marbles. }\end{array}$ \\
\hline 5 & Metamorphic rocks & $\begin{array}{l}\text { Undifferentiated gneiss, para- } \\
\text { gneiss, and metagabbro. }\end{array}$ \\
\hline 6 & Igneous rocks & All igneous rocks. \\
\hline 7 & Coastal Plain sediments & $\begin{array}{l}\text { Uncemented or partially cemented } \\
\text { marine clay, silt, sand, and } \\
\text { gravel. }\end{array}$ \\
\hline
\end{tabular}

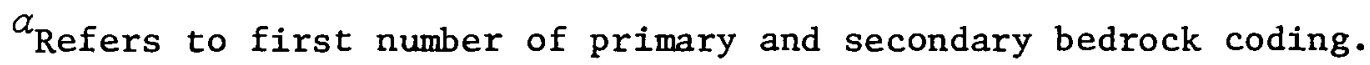

Table 10. Classification of structural attitude

\begin{tabular}{cl}
\hline Class number & \multicolumn{1}{c}{ Description } \\
\hline 1 & Flat-lying or no apparent structure. \\
2 & Domed, arched, flexed, warped, or openly folded. \\
3 & l'ightly folded. \\
4 & Magaocoplcally faulted. \\
\hline
\end{tabular}

$a_{\text {Refers }}$ to second number of primary and secondary bedrock coding. 
ORNL-DWG-75-11753

|

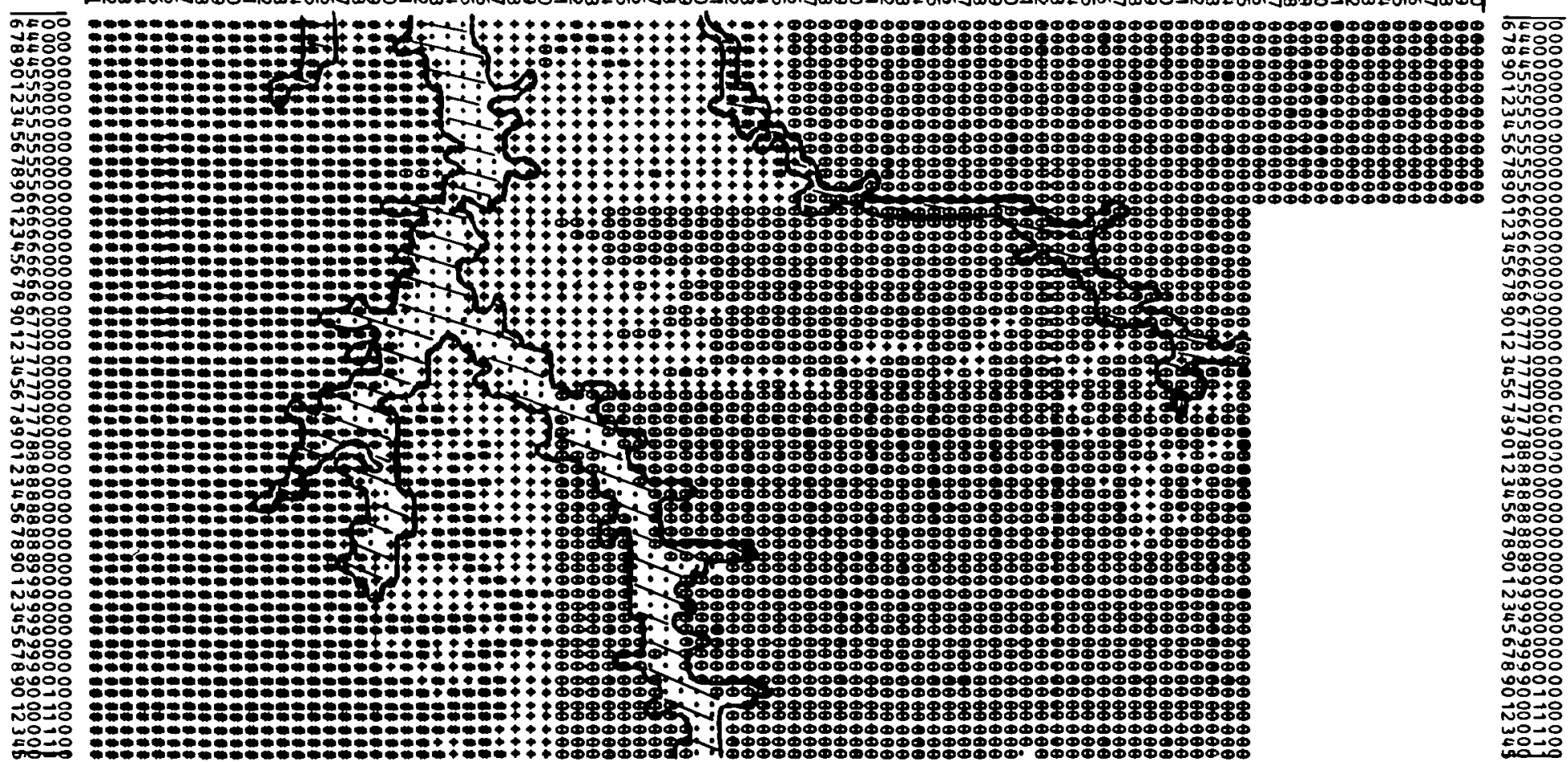

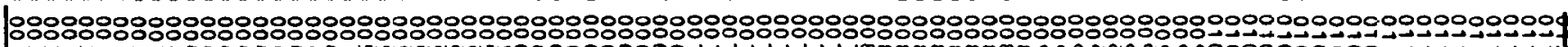

|

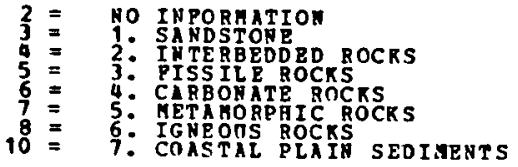

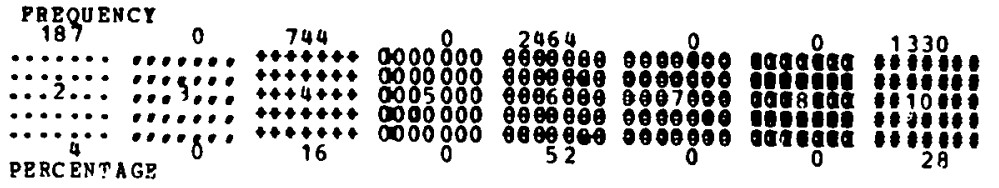

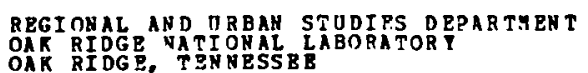

Fig. 5. Kentucky Lake NEC surrogate area: classification of lithology (bedrock)。Scale: 1:590,000. 


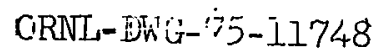

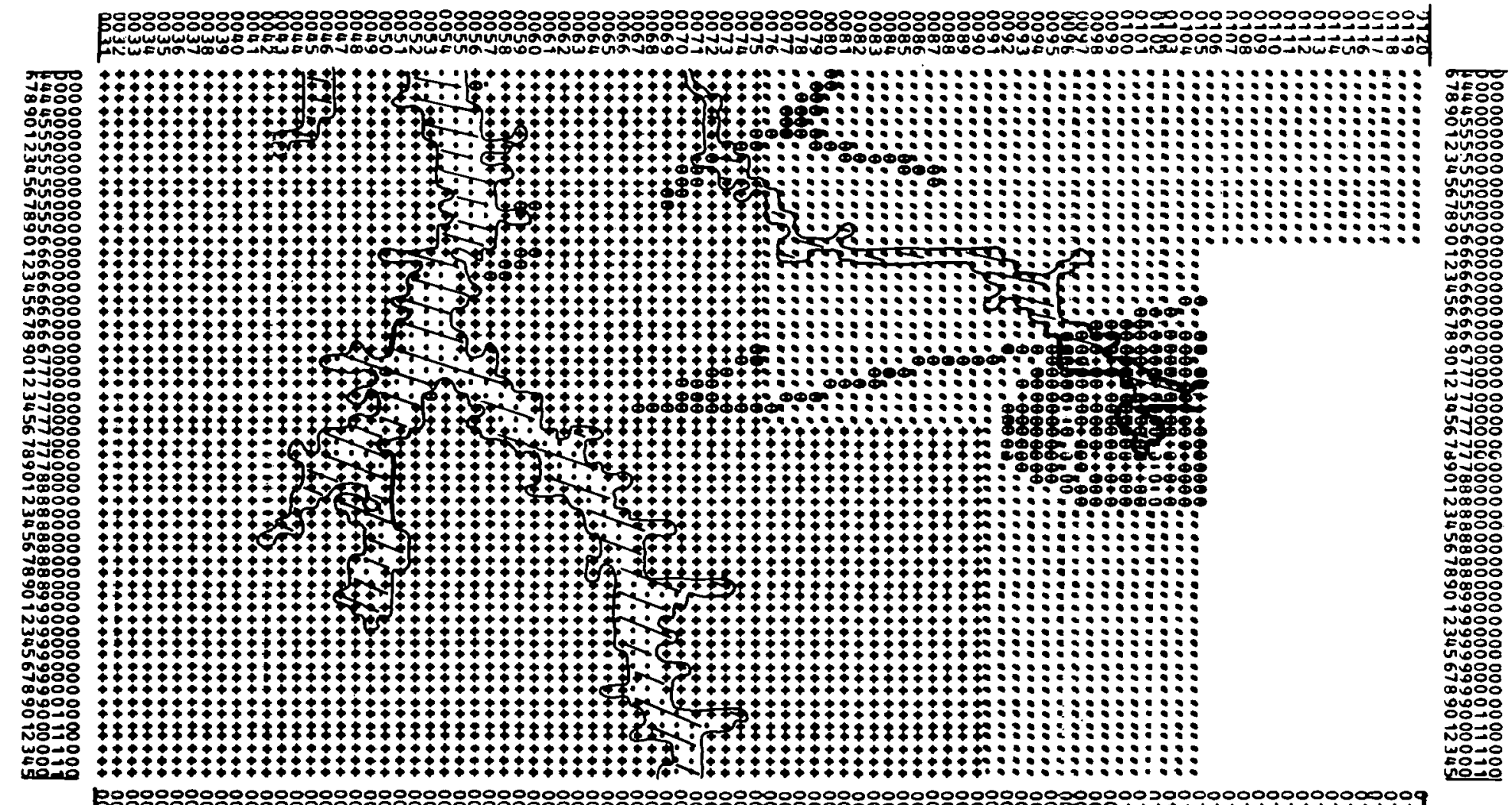

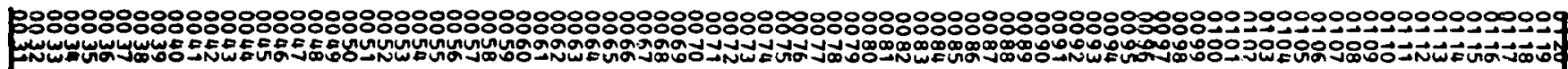

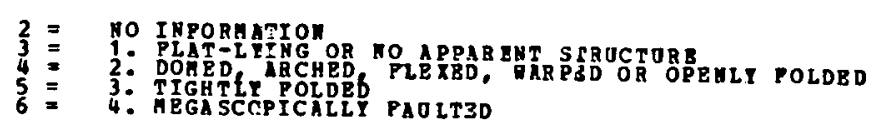

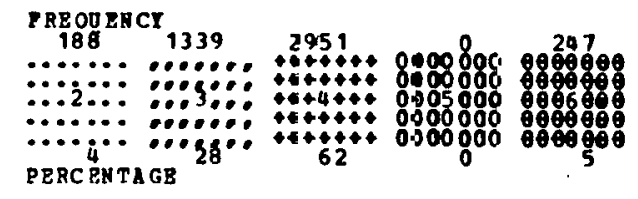

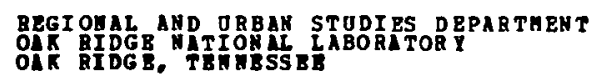

Fig. 6. Kentucky Lake NEC surrogate area: classificetion of structural attitude (bedrock). Scale: 1:590,000. 


\subsection{Land Use}

Three variables were constructed on the basis of existing land use information - primary, secondary, and tertiary land use. The primary, secondary, and tertiary designations deal with dominance in a cell. For example, if the primary land use is residential, then over $50 \%$ of the land area of the cell is in residential use. The land use variables are categorized into four classes of uses: (1) urban (residential, commercial, and industria1), (2) water (surface), (3) open (nonforested, unused, including agriculture), and (4) forest (vegetated). The material was coded from the USGS topographic maps.

Maps of primary, secondary, and tertiary land use are contained in Figs. 7, 8, and 9 respectively. Because all three categories will exist in cach cell, three sepalate alsplays are required. Existing land use is related to conflicting uses of the potential NEC site as well as site clearing and preparation costs. As illustrated in the maps, the dominant land cover of the area is forest ( $61 \%$ of the study area's primary use). Very little of the region is classified as dominantly urban; urban cells are indicated for Big Sandy, Cumberland City, Dover, Erin, McKinnon, and Tennessee Ridge, Tennessee. Approximately 30\% of the region is unforested open land. Although this may appear to present siting opportunities because of reduced clearing, it is necessary to remain cognizant of active farm communities that are susceptible to disruption.

\subsection{Public Ownership}

Public ownership was taken from USGS and TVA maps. Six areas, or types of areas, in public ownership were identified: (1) Fort Campbell military, (2) TVA recreation, (3) Land-Between-the-Lakes Recreation Area, (4) Fort Donnelson National Battlefield, (5) national wildlife refuges, and ( $\bar{b}$ ) other public recreation lands (Nathaniel Bedford Forrest Memorial State Park, Paris Landing State Park, and Stewart State Forest). Public ownership can serve as a restrictive factor. (e.g., of recreation land) or an attractive factor (e.g., unused military bases and TVA nonrecreational 1and). Figure 10 contains a map of ownership for the study area. 
ORNL-DWG-75-1.1752

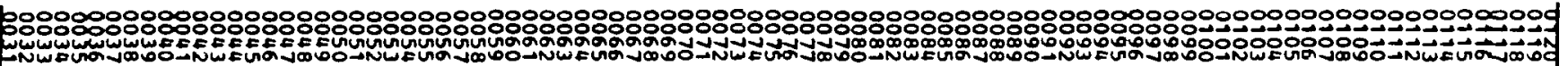

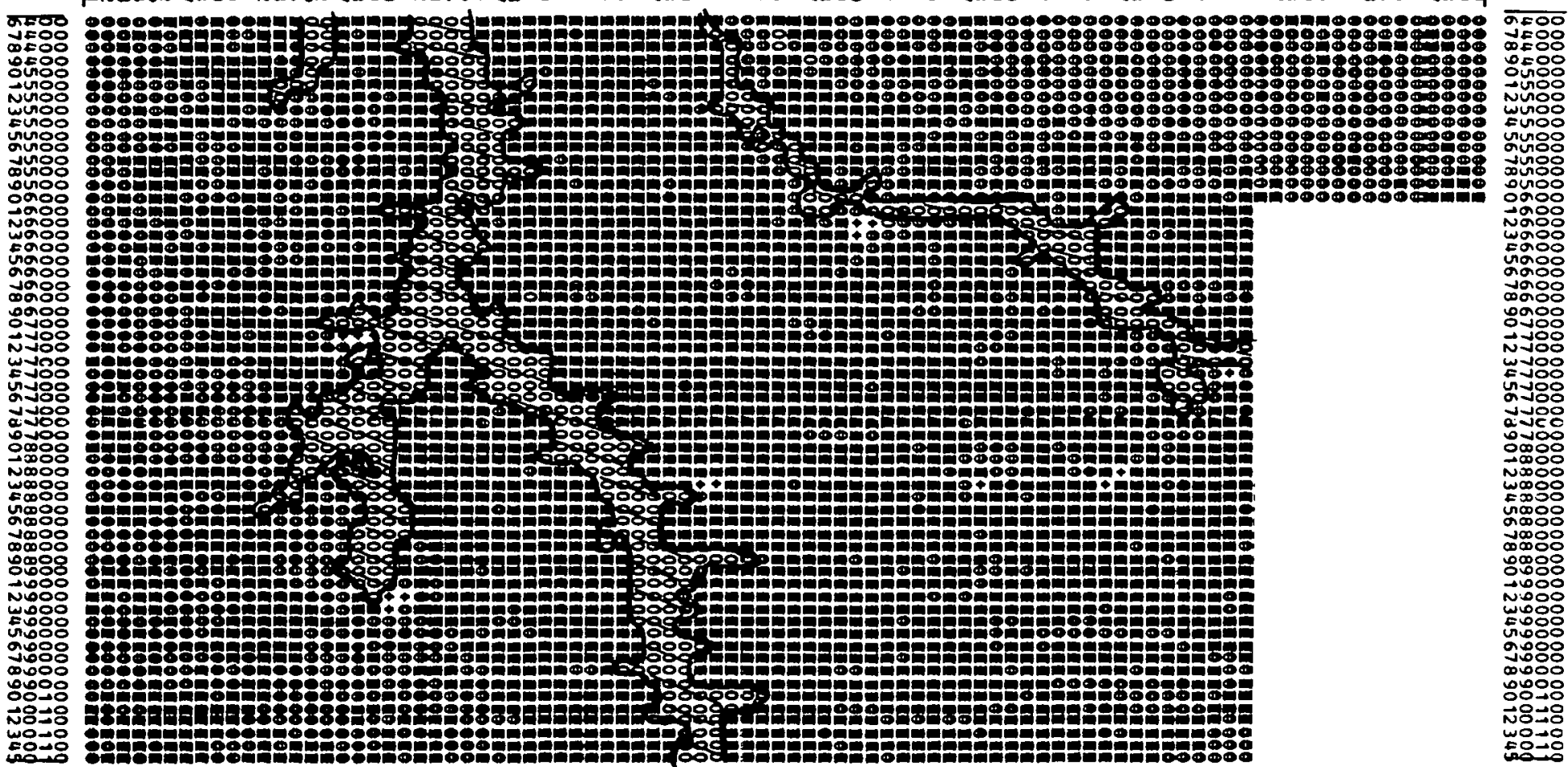

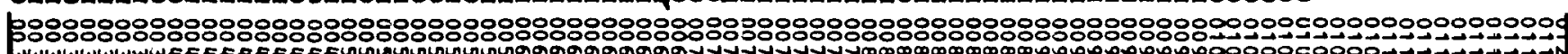

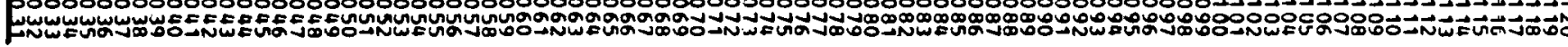

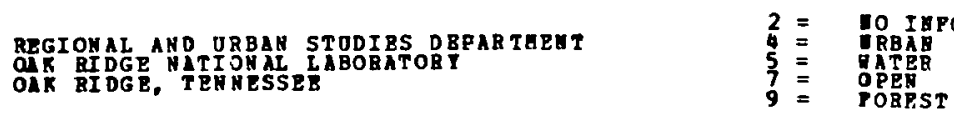

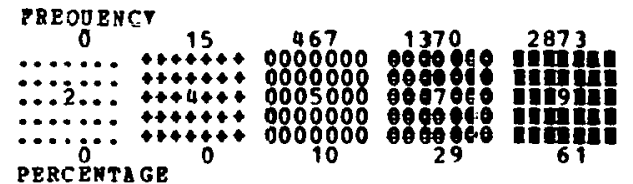

Fig. 7. Kentucky Lake NES surrogate area: primary land use. Scale: 1:590,000 
ORNL-DWG-75-11994

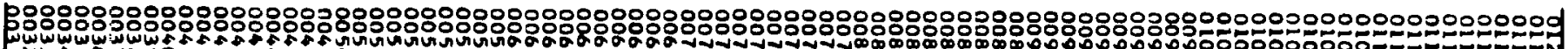

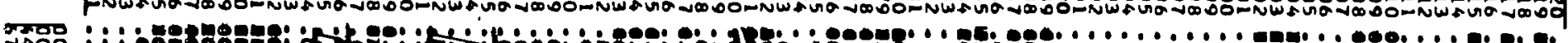

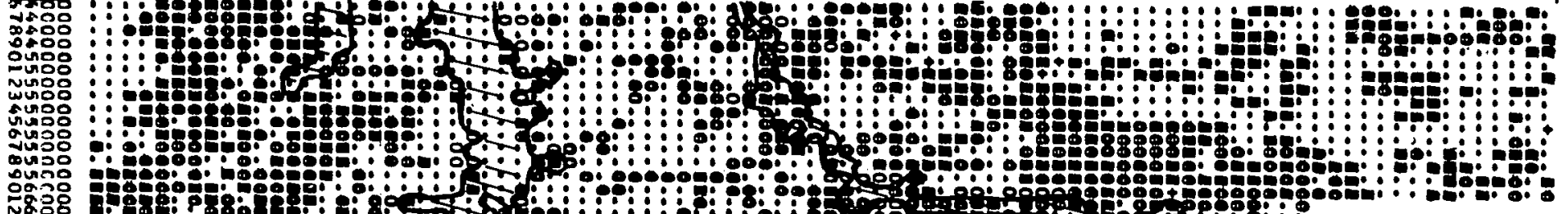

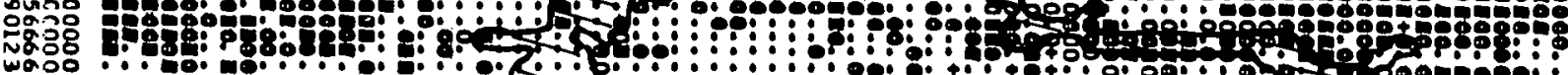

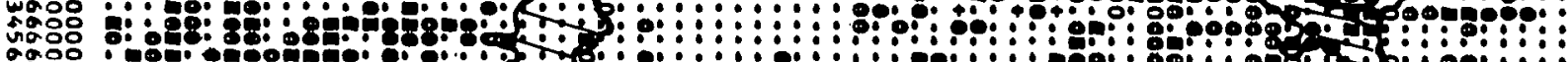

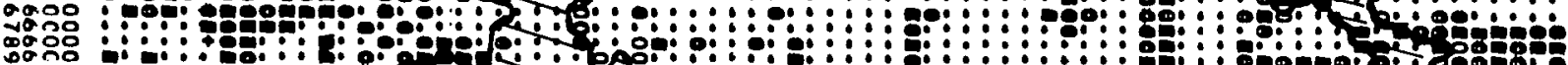

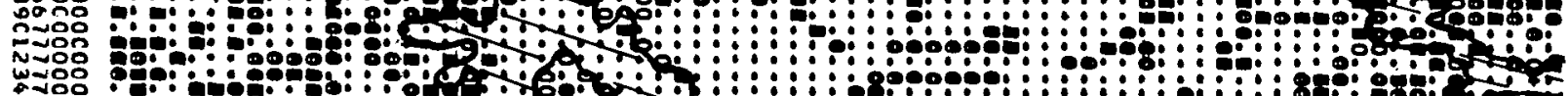

wำ

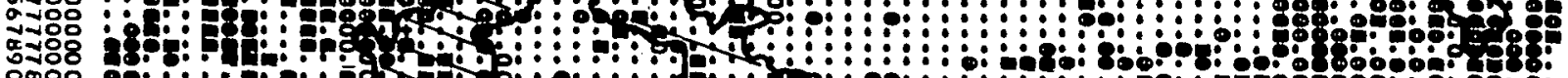

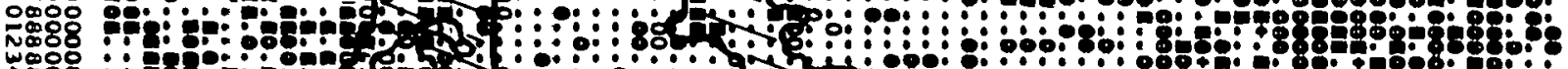

4008

0.0

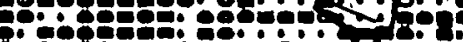

forop:

:

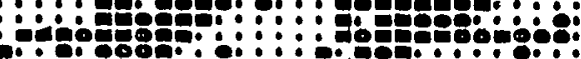

\section{8f:}

:

: :

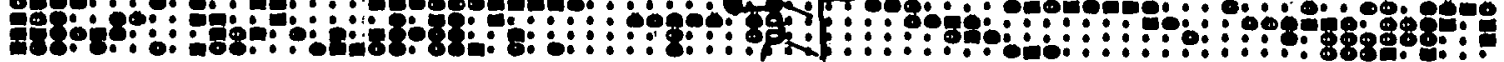

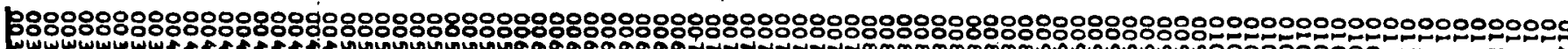

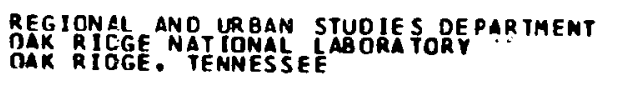

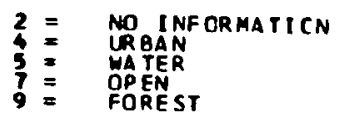

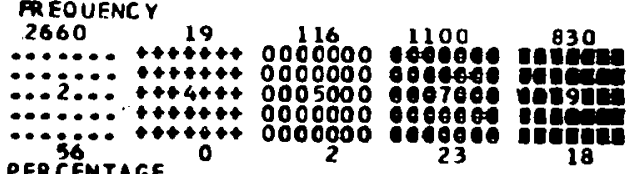

Fig. 8. Kentucky Lake NEC surrogate area: secondary land use. Scale: $1: 570,000$. 
ORVL-DWG-75-11996

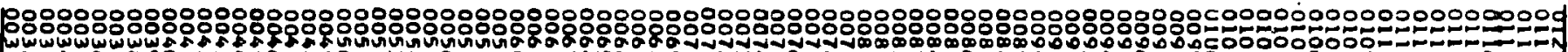

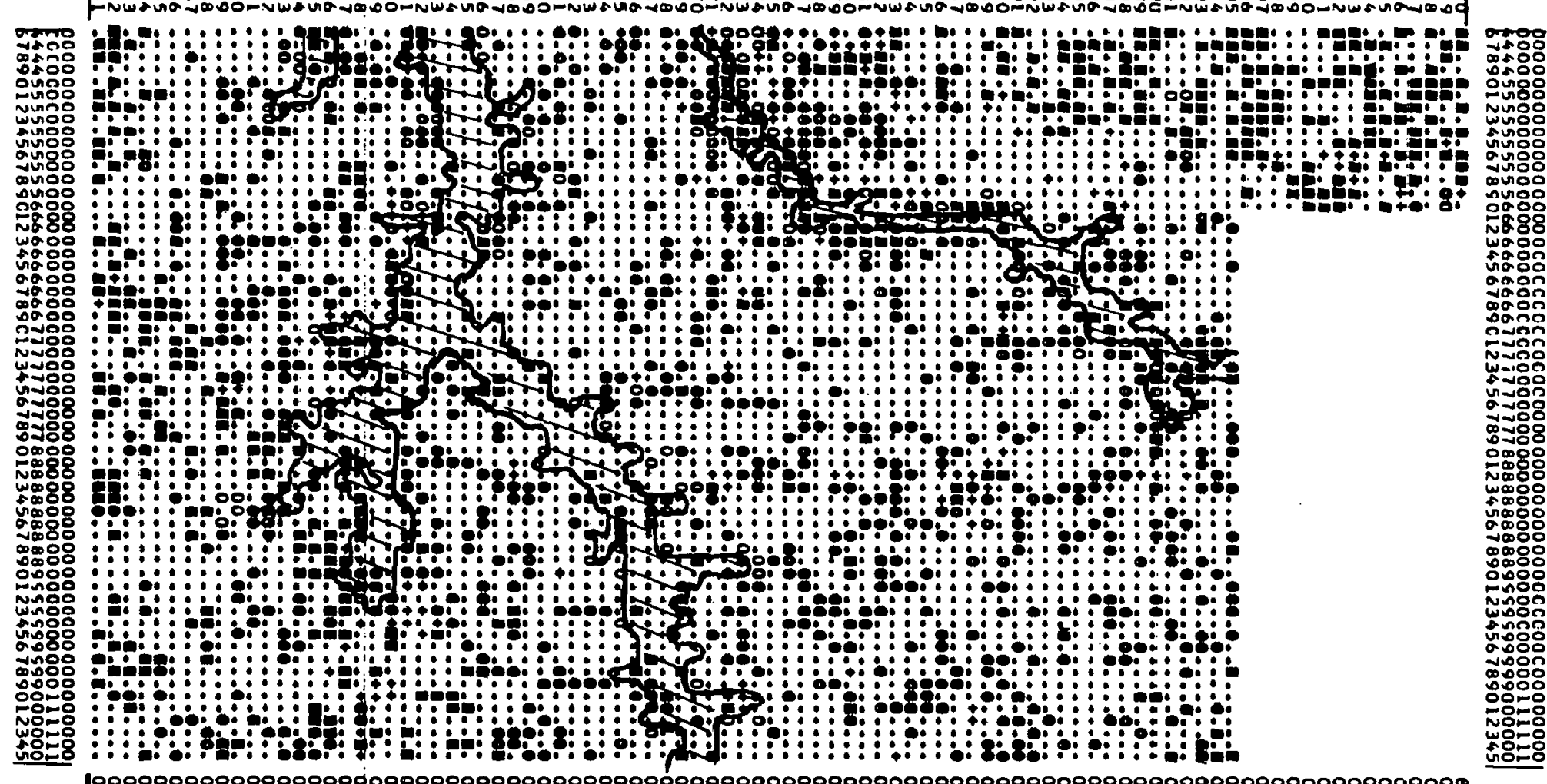

|

\begin{tabular}{|c|c|c|}
\hline 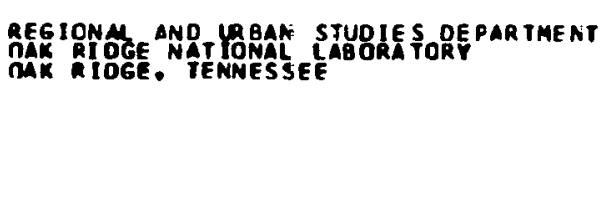 & 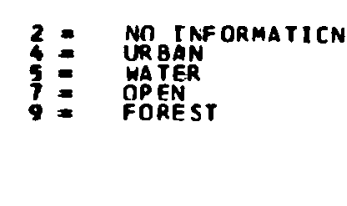 & 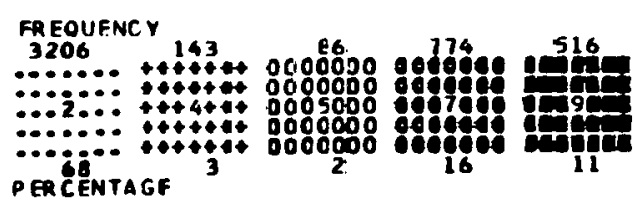 \\
\hline
\end{tabular}

Fig. 9. Kentucky Lake NEC surrogate area: tertiary land use. Scale: 1:570,000. 
OPNL-DWG-75-12004

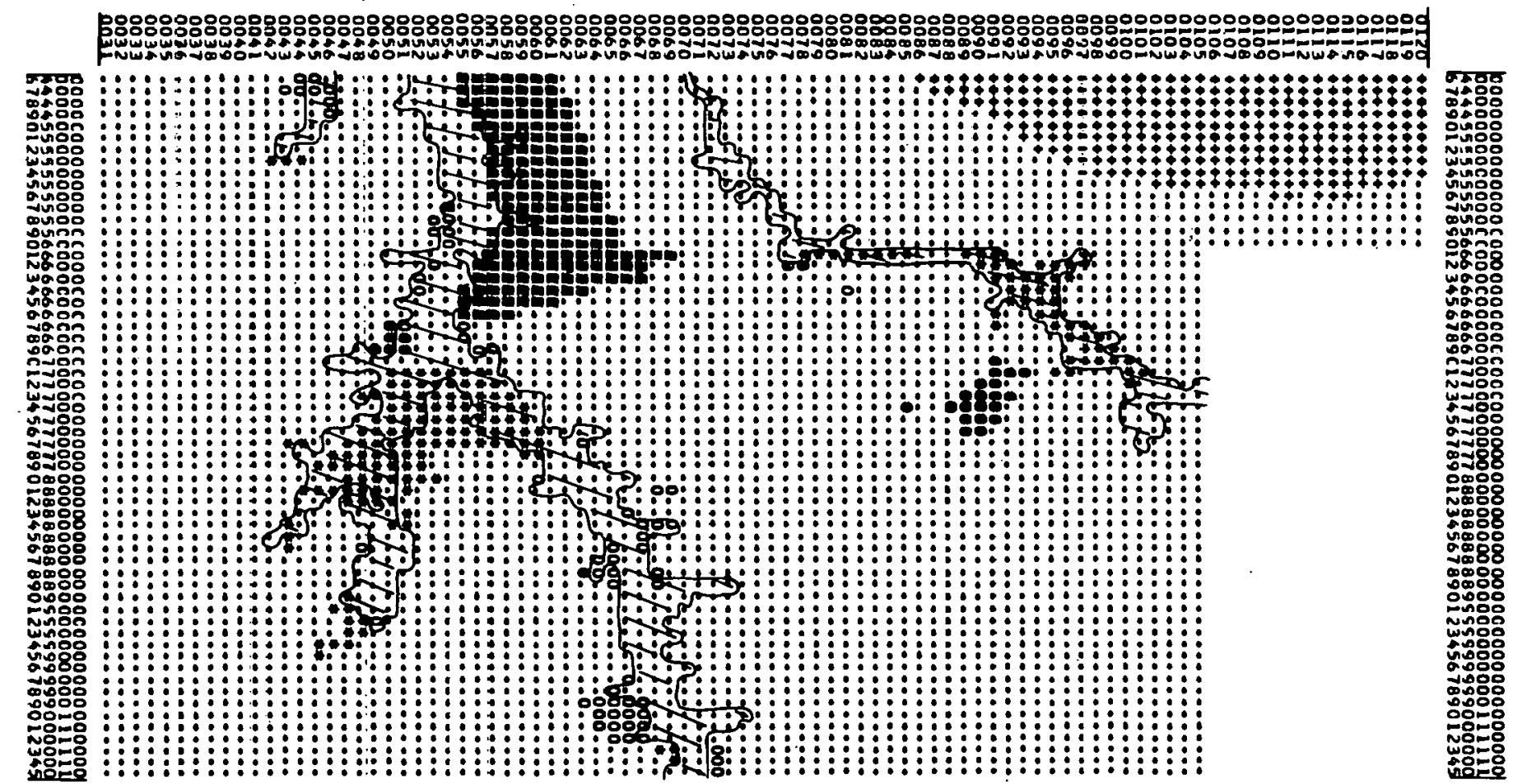

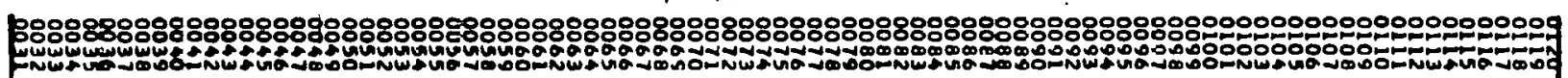

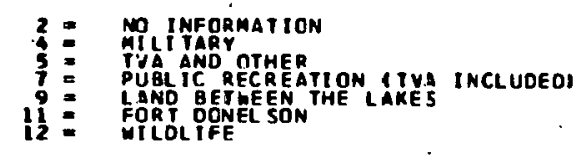

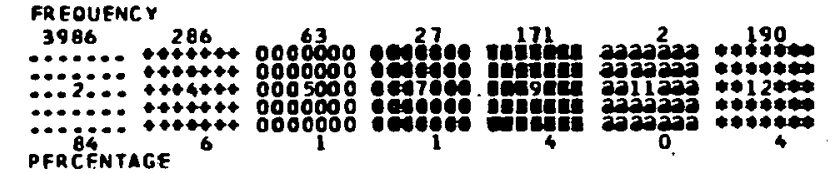

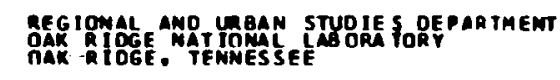

Fig. 10. Kentucky Lake NEC surrogate area: ownership. Scale: $1: 630,000$. 
Sixteen percent of the region is in public ownership. This is significant for both restrictive and attractive reasons. The Fort Campbell area (military) constitutes $6 \%$ of the region. The three recreation-oriented segments of public land comprise $5 \%$ of the area while the wildlife refuges add another $4 \%$ to the likely-to-be-reserved segment of land. The LandBetween-the-Lakes area, Fort Campbell, and the wildlife refuges, consisting of large contiguous tracts of land, are the most dominant of the publicly owned lands.

\subsection{Population Density}

United States Atomic Energy Commission guidelines ${ }^{4}$ and research into the effects of toxic materials on populations have indicated that power generation sites should be in sparsely settled areas if other criteria do not mitigate against use of such areas. To examine the distribution of population across and around the study region, the facilities of the ORNL Regional and Urban Studies Technical Information Center were used.

This process involved the calculation of population densities across a 170-acre cell grid. The total procedure consisted of the following four steps:

(1) Identify population centroids for a large area surrounding the Kentucky Lake area (from Census tapes).

(2) Assign these centroids to the appropriate cells in a geodetic grid.

(3) Calculate the population densities for those cells containing centroids.

(4) Calculate population densities for all cells in the grid by using an intorpolation procedure on the cells containing. centroids.*

*For a more detailed description of the interpolation technique, the reader is referred to Ref. 5 . 
The gridded population density contains discrete values of persons per square mile. A map of density for the Kentucky Lake area is reproduced in Fig. 11. The map illustrates the sparsely settled nature of the Kentucky Lake area. Most of the cells (91\%) contain densities of less than 31 persons/sq mile. The small clusters of increased density (mostly 31 to 100 persons/sq mile) represent the influence of Dover, Erin, Fort Campbell-Clarksville, Paris, and Puryear. Population density does not appear to be a limiting factor for NEC siting in the region.

\subsection{Proposed Development}

Industrial development sites and proposed major road corridors were rnded inten the cellular data base under the heading of "Proposed Development." These areas were identified on the basis of maps provided by the Tennessee State Planning office. The data was coded in a binary manner indicating presence or absence in a cell. A map. of these areas is provided in Fig. 12. Industrial development sites may indicate land suitable for NEC use that has been identified by other sources (such as local chambers of commerce). It may also indicate potential conflict with other industrial developments if industrial sites are limited in the area.

\subsection{Proximity to Population}

The site population factor (SPF) was used to indicate the nearness of a site to a densely populated area. An SPF(30) value was calculated for every cell of the study area. The values that were calculated were very low, indicating sparse regional settlement. These values were categorized into two classes - SPF(30) values of 0.022 to 0.043 and $\operatorname{SPF}(30)$ values of 0.043 to 0.133 . "Neither of these categories is limiting in terms of NRC regulations. Figure 13 contains a map of SPF values for the Kentucky Lake surrogate area. The SPF mapping indicates very low values across the entire region.. The Fort Campbell-Clarksville, Paris, and Puryear areas show up in the northeast and western portions of the region. However, communities such as Big Sandy, Dover, and Erin were not outlined by the SPF measure at all. 
ORRL-DWG-75--1.1.46

Poobooobo

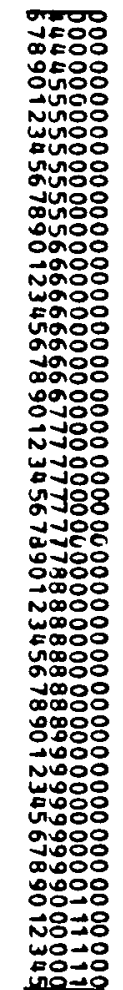

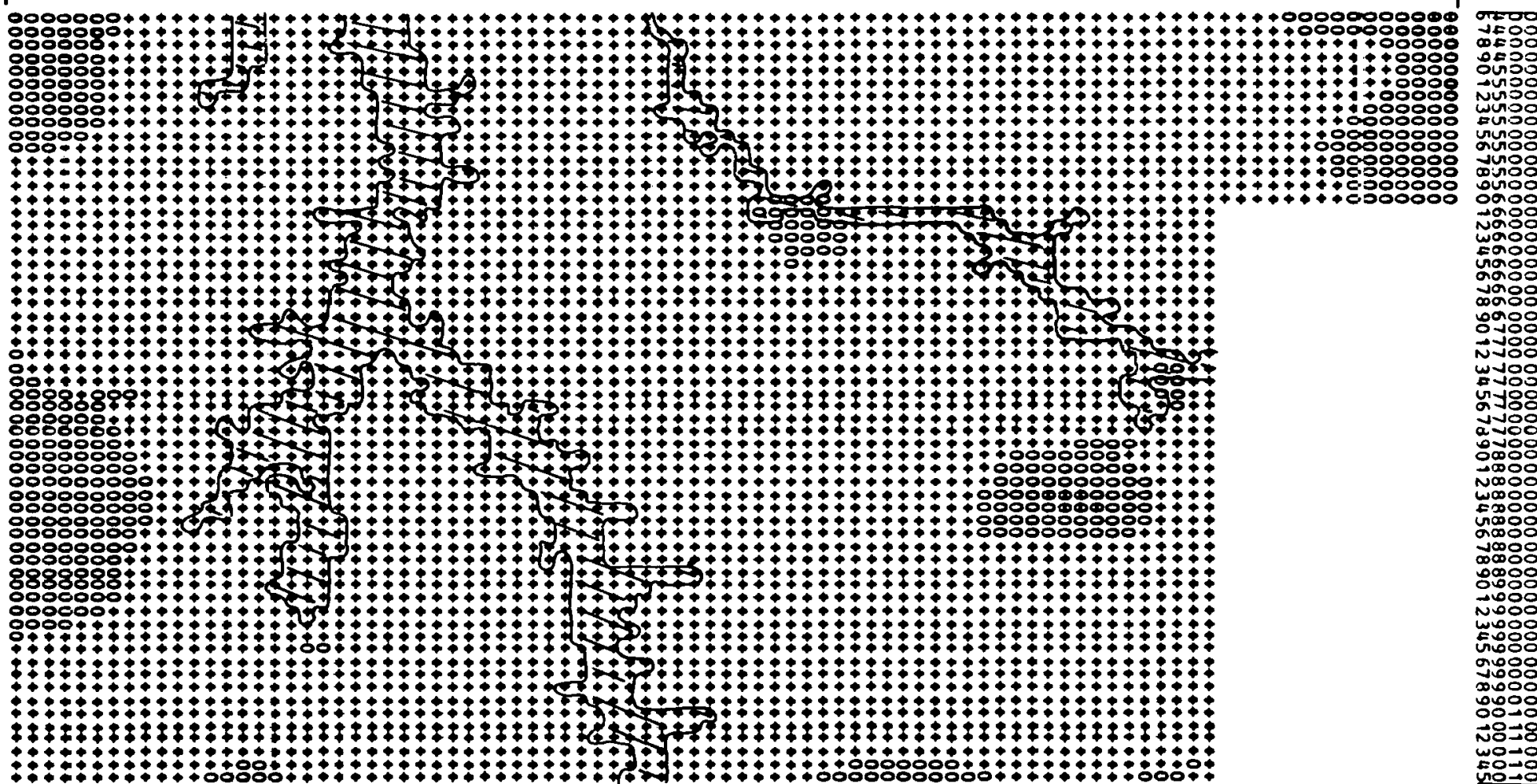

 |

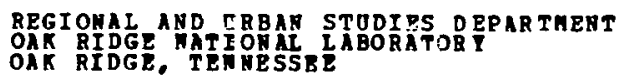

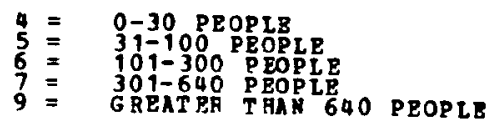

Fig. 11. Kentucky Lake NEC surrogate area: population density. Scale: $1: 560,000$ 。

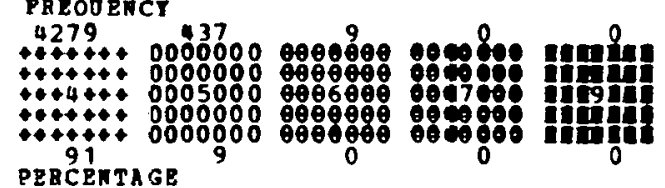


OF'NL-DWG-75-11999

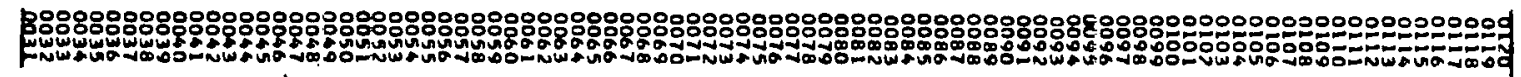

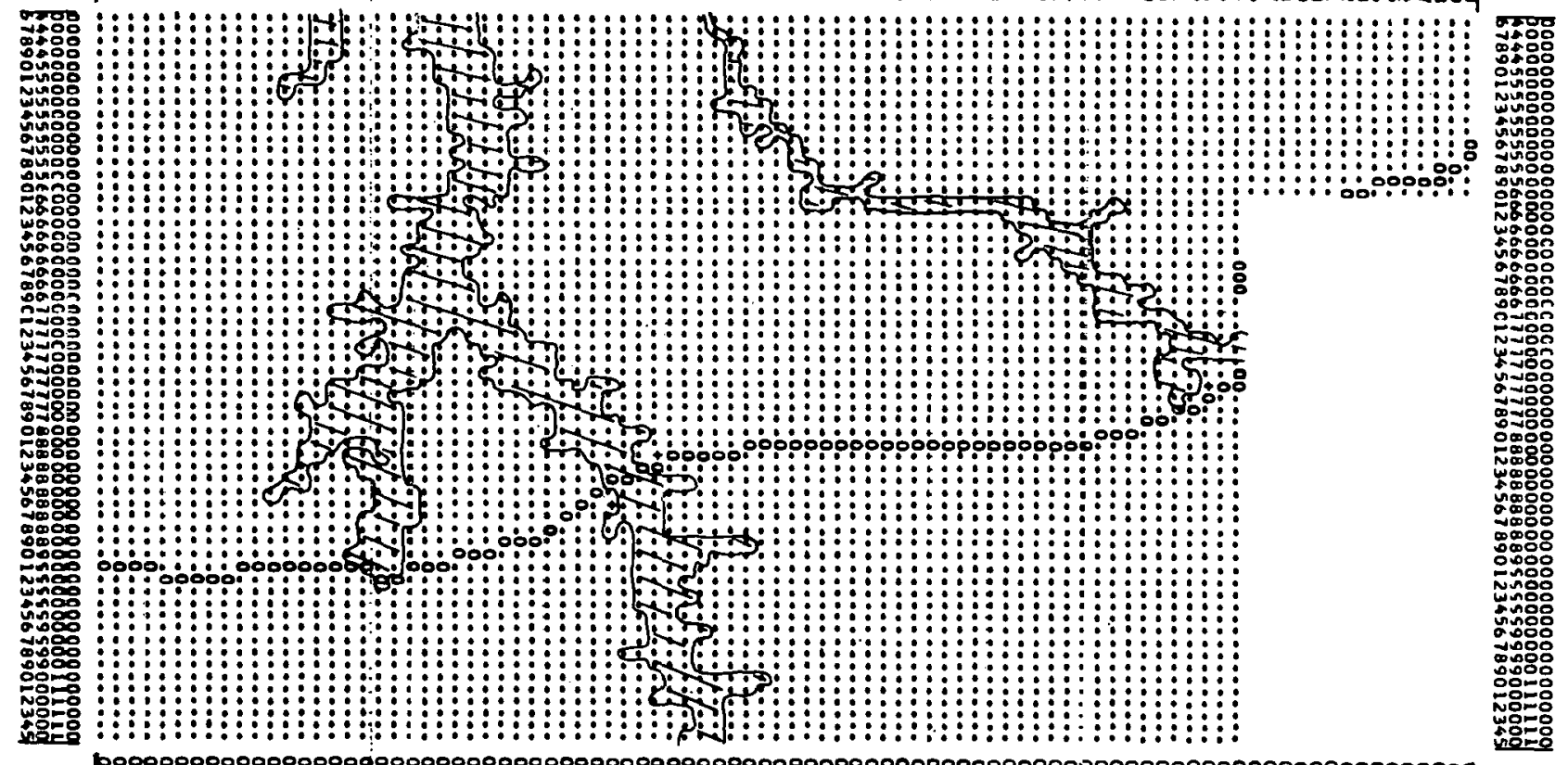

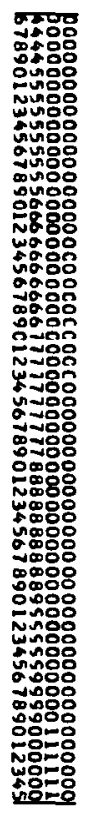

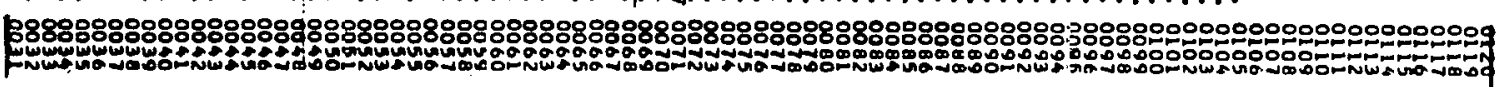

PROPOSEO DF VELOPMEMT

MEC - KENTUCKY LAKE PROJECT

LEGEND

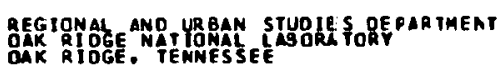

5:

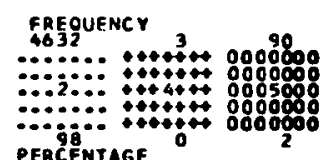

Fig. 12. Kentucky Lake NEC surrogate area: proposed development. Scale: $1: 685,000$. 
ORIVL-DWG-75-1.1758

Roobooooo

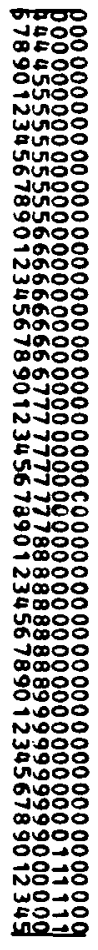

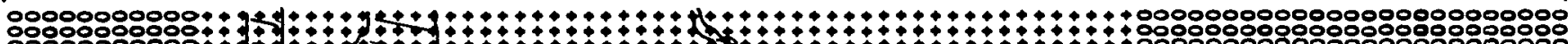

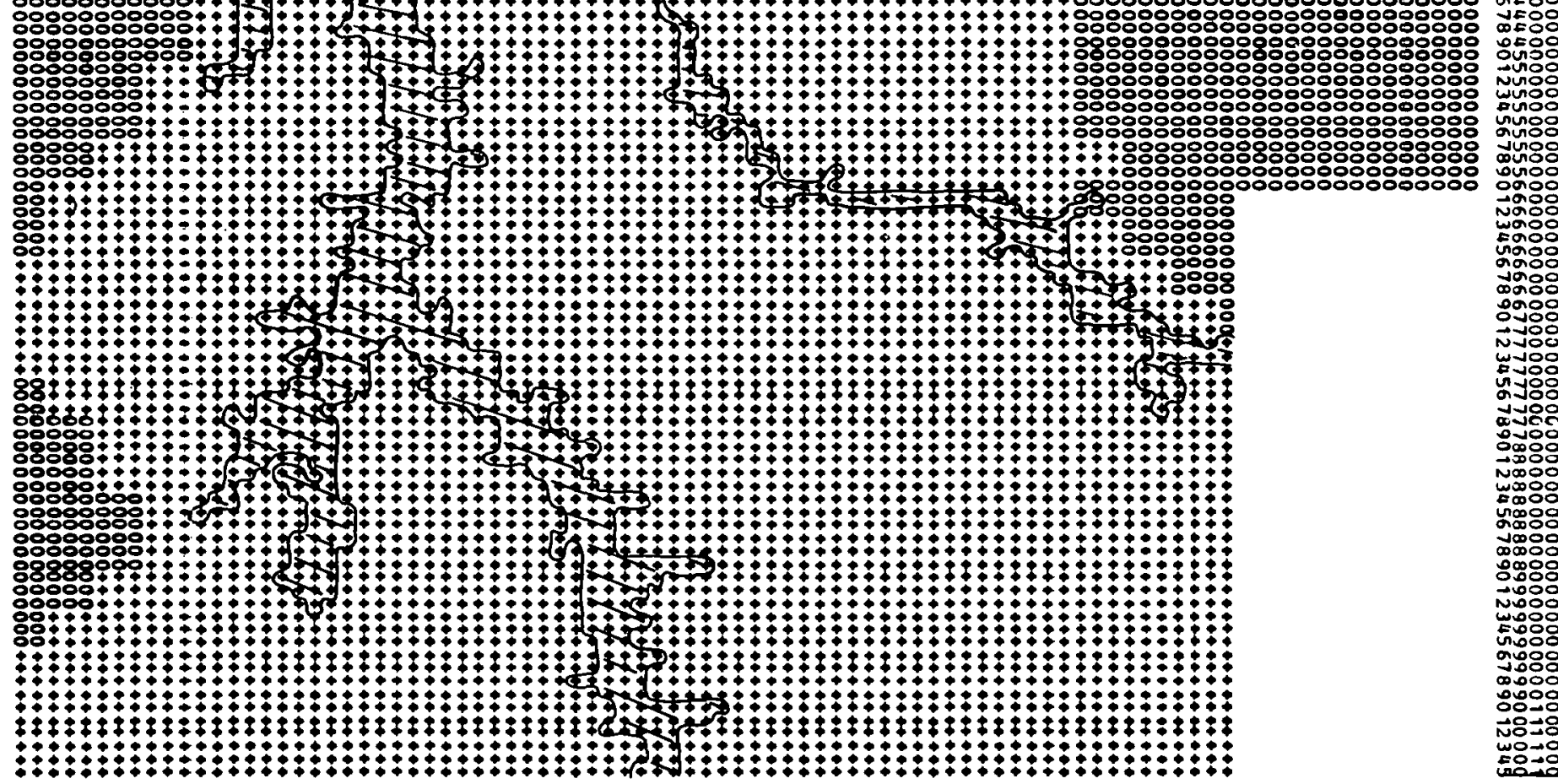

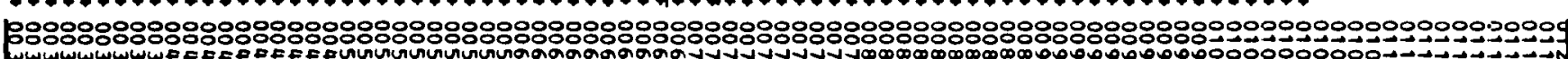

H

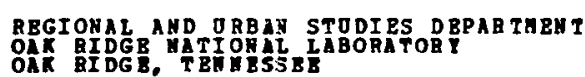

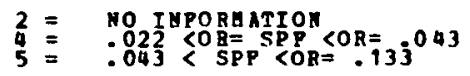

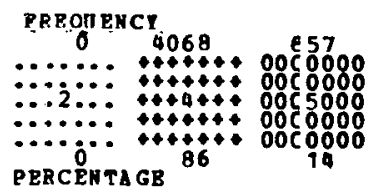

Fig. 13. Kentucky Lake NEC surrogate area: proximity to population. Scal : $1: 590,000$. 


\subsection{Proximity Variables}

In addition to the primary data items outlined in this section, a set of variables was created to reflect the proximity or nearness of a cell to a data feature. The proximity to a variable is often as critical as whether a cell contains the item. For example, whereas a cell that was identified as water under the land use variable would be excluded for site location, the nearness of adjacent cells to water is important for cooling system considerations. The resultant data, described as proximity values, were written onto the data tape on the cellular records. Proximity values are generated by scanning out from a cell containing a data item (e.g., a railroad) and assigning cells on the scan line a code as a function of distance from the source cell. Proximity values were created for proximity to (1) railroads, (2) recreation areas, (3) roads, (4) transmission lines, and (5) water. Linc printer plots for these five variables for the Kentucky Lake area are contained in Figs. 14 through 19.

The plots indicate that about $40 \%$ of the cells in the center of the region running east to west are within 6 miles of a rail 1ine. However, all the cells are within 6 miles of a light-duty roadway; hence, access might be provided by road where rail is not feasible. Proximity to medium-duty roads is more limited; some $58 \%$ of the region is within 6 miles of a medium-duty road. A majority of the area lies close to an existing transmission network for power during the construction phase. Water is equally available. Fifteen peictul of the scudy region is within 1 mile of a significant water body, and $77 \%$ is within 6 miles of water. The northeast and southeast corners of the region are the most significant of the areas located farthest away from water.

\subsection{Railroads}

Railroads and proximity to railroads indicate a partial measure of accessibility for materials for construction and fuel and waste shipments. Railroads were digitized from the USGS topographic series maps $(1: 24,000$ scale). Values indicating presence or absence of a railroad in the cell 
OPNJL-DWG-75-1.1.75-7

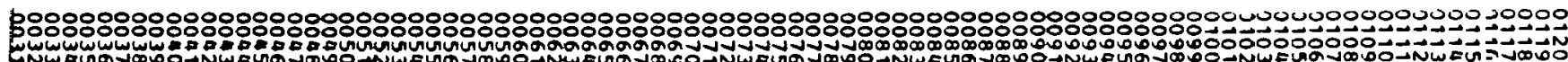

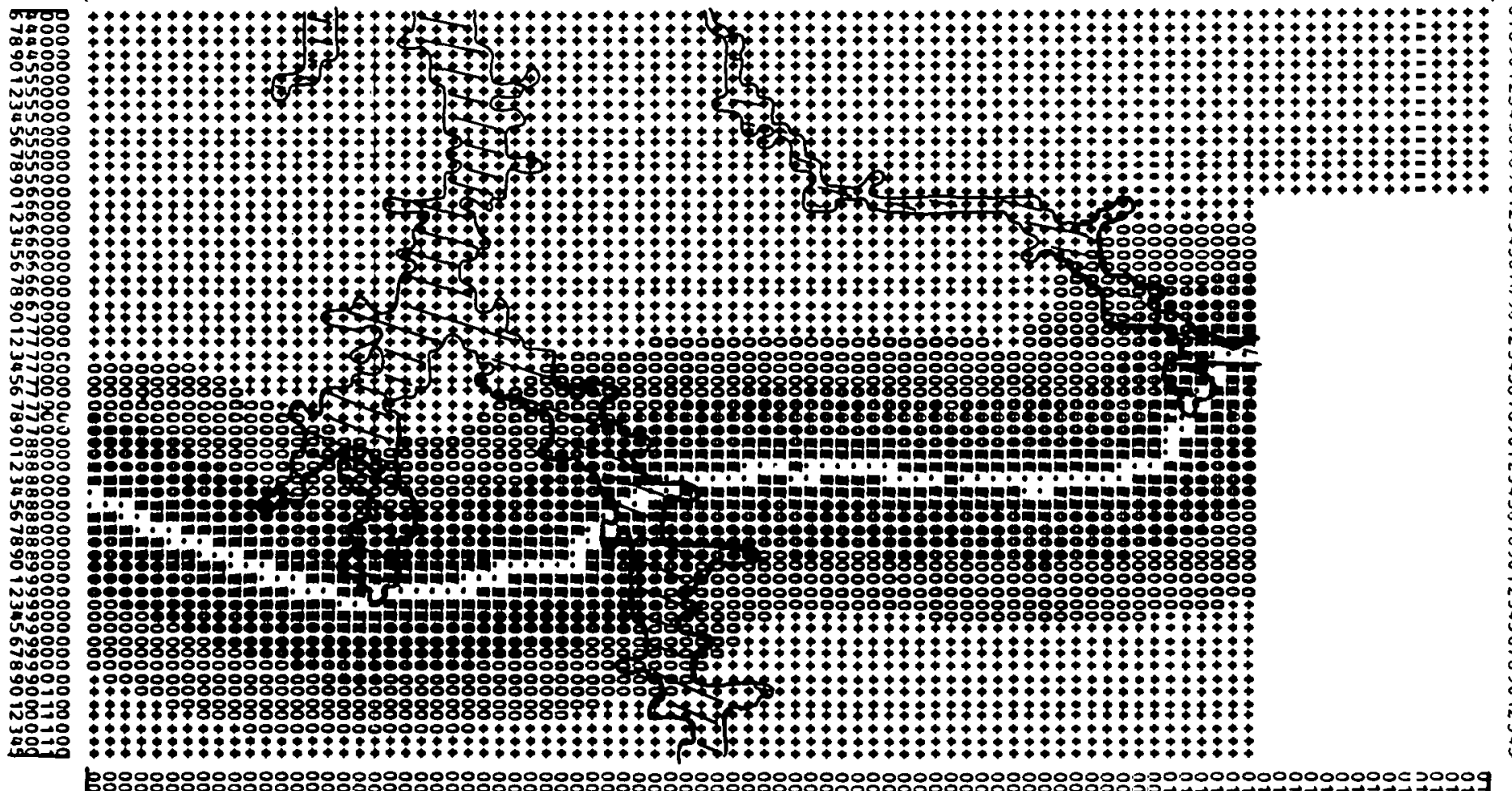

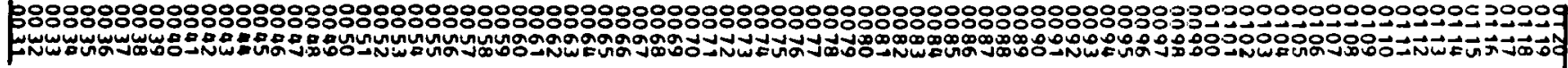

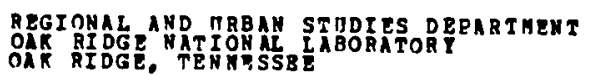

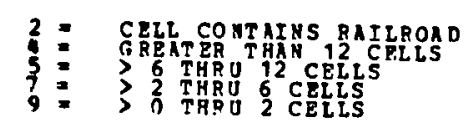

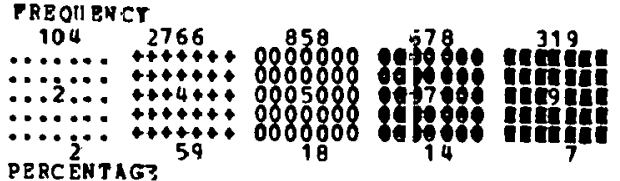

Fig. 14. Kentucky Lake NEC surrogate area: proximity to railrcads. Scale: 1:590,000。 
ORNL-DWG-75-E1997

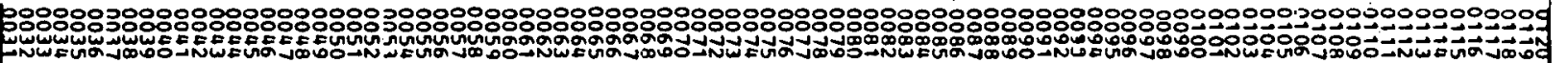
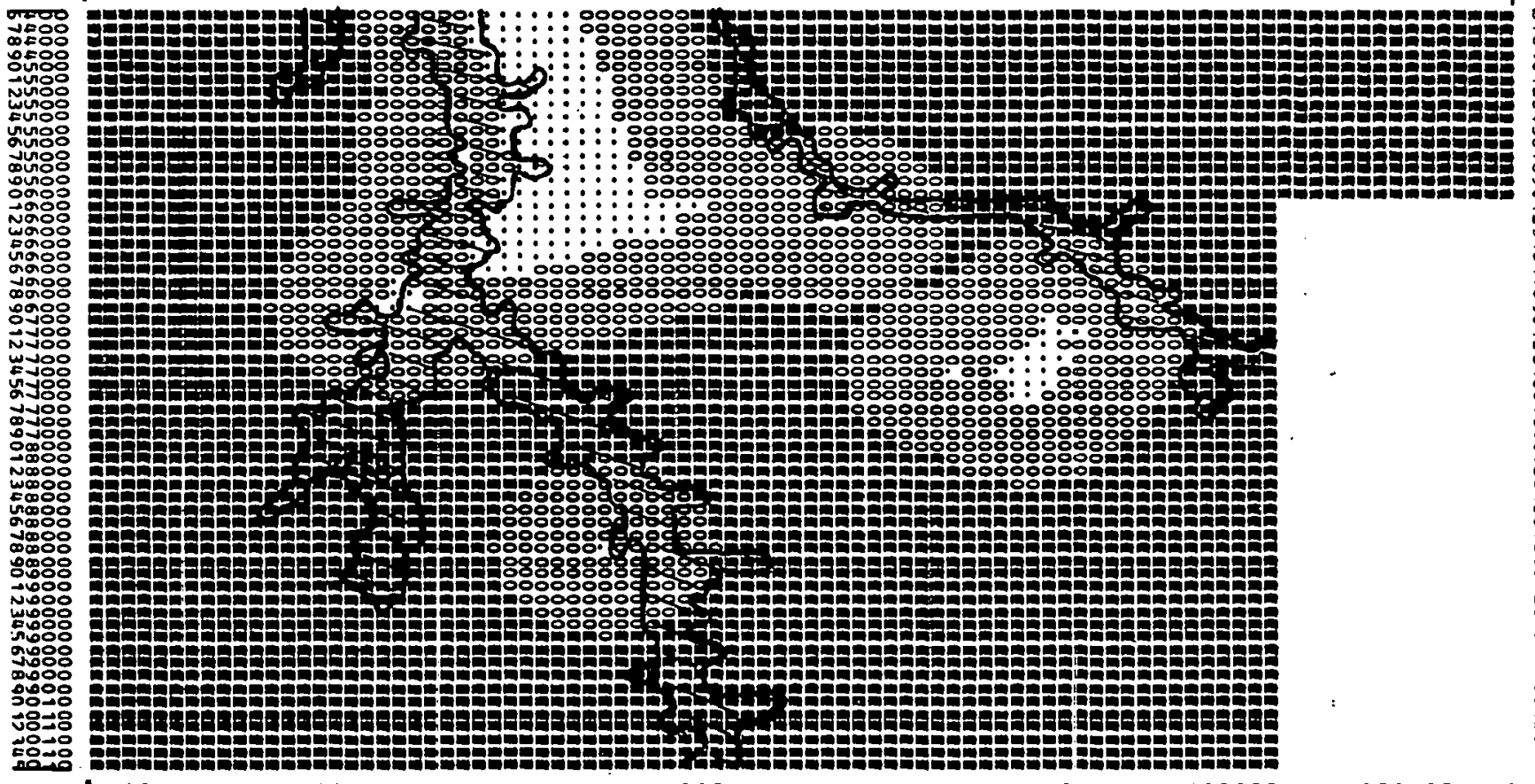

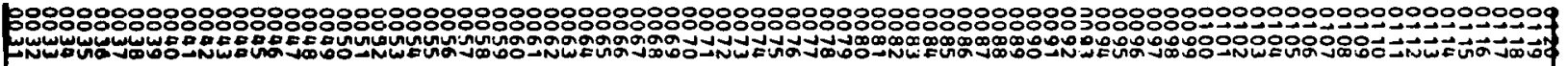

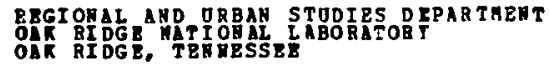

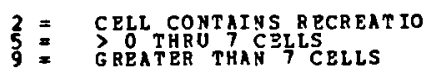

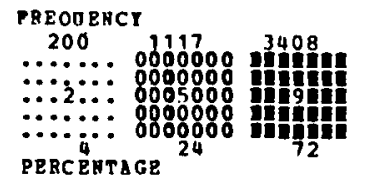

Fig. 15. Kentucky Lake NEC surrogate area: proximity to recreation area. Scale: 1:630,000. 
ORNL-DWG-75-11749

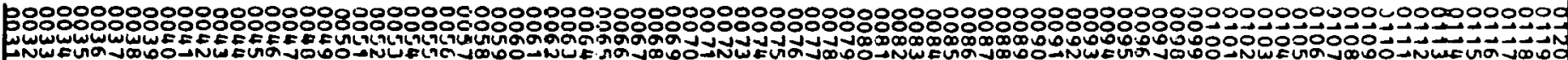

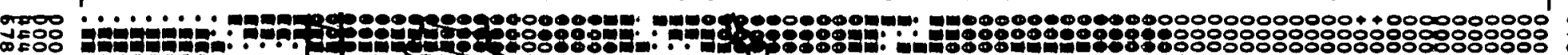

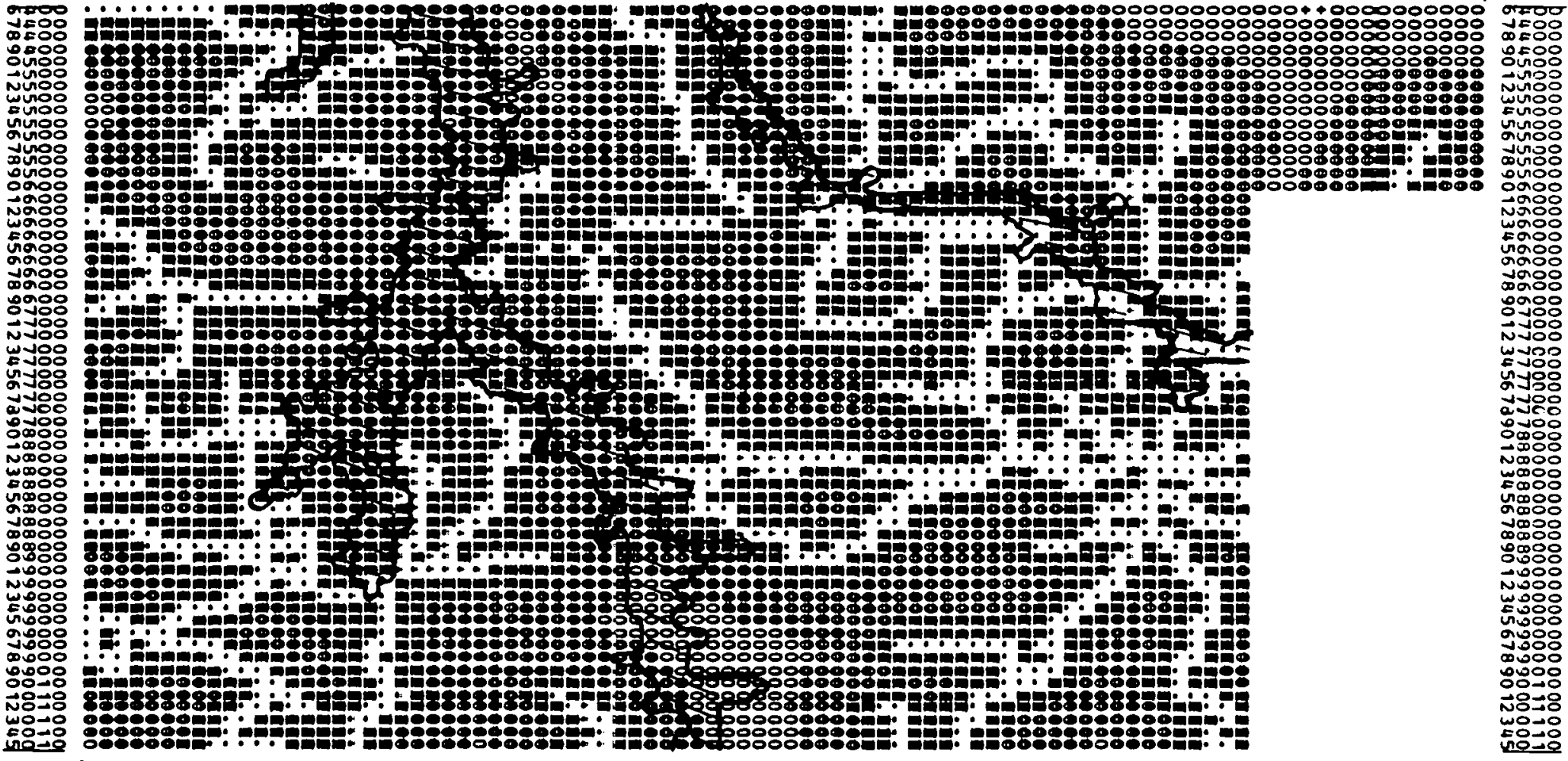

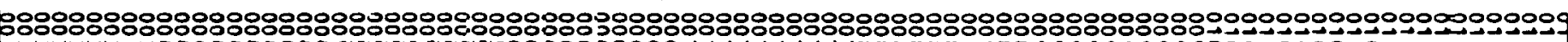
F

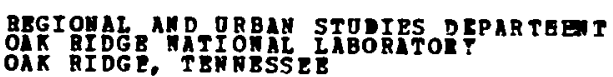

Fig。 16. Kentucky Lake NEC surrogate area: (light and light/heavy;. Scale: 1:560,000.

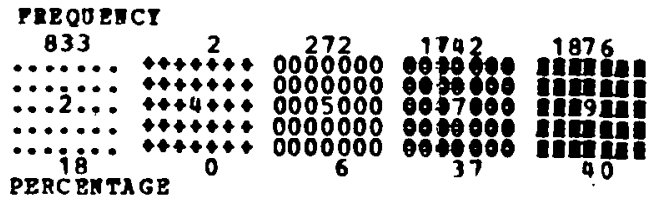

proximity to roads 
ORNL-DWG-75-11754

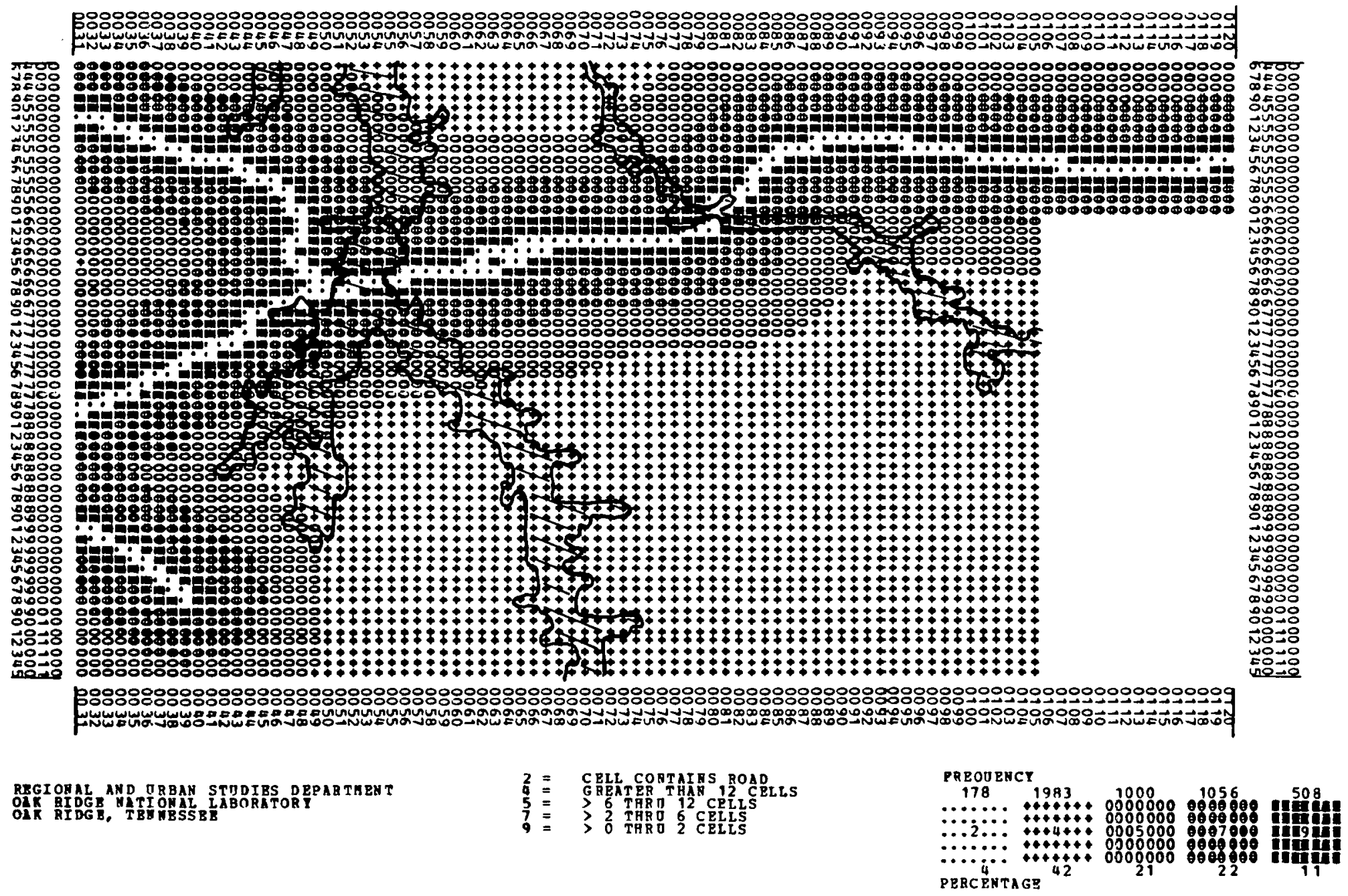

Fig. 17. Kentucky Lake NEC surrogate area: proximity to roads (heavy and 1ight/heavy). Scale: 1:590,000. 
ORIL-IWG-75-11.756

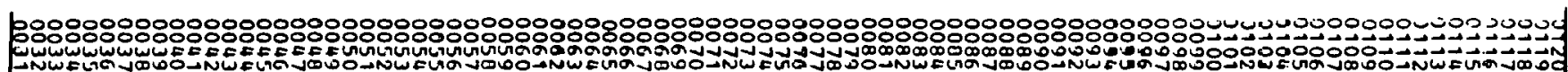

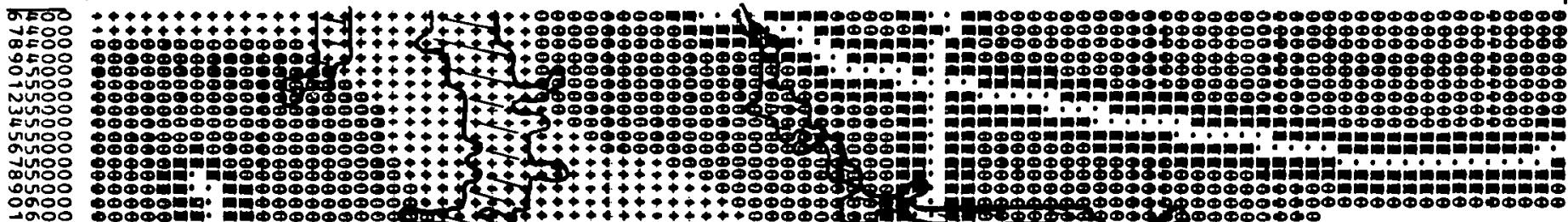

今aำ

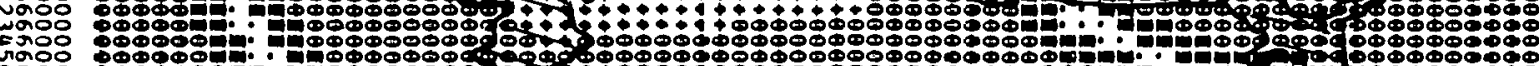

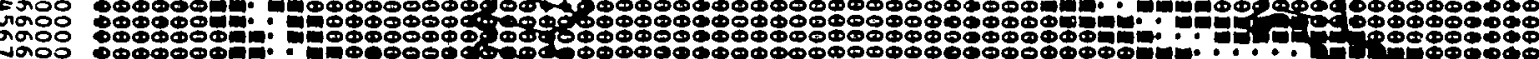

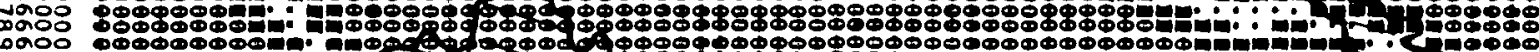

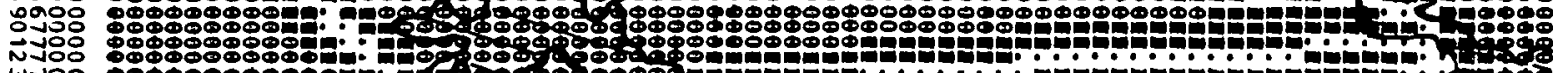

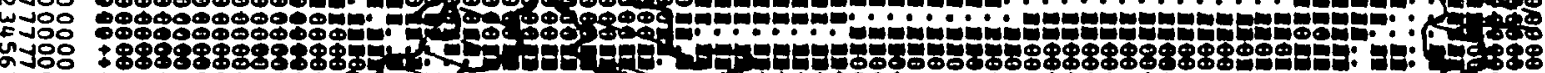

a voo

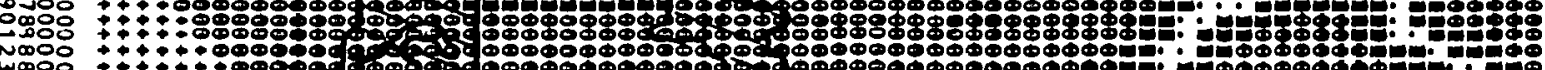

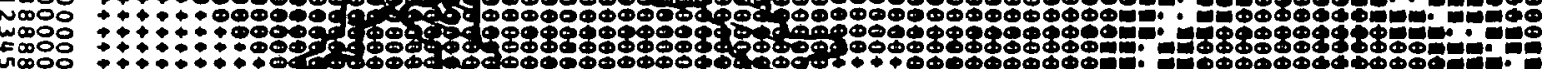

sio.

แัฒำ

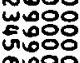

1008

싱ㅇㅇㅇ

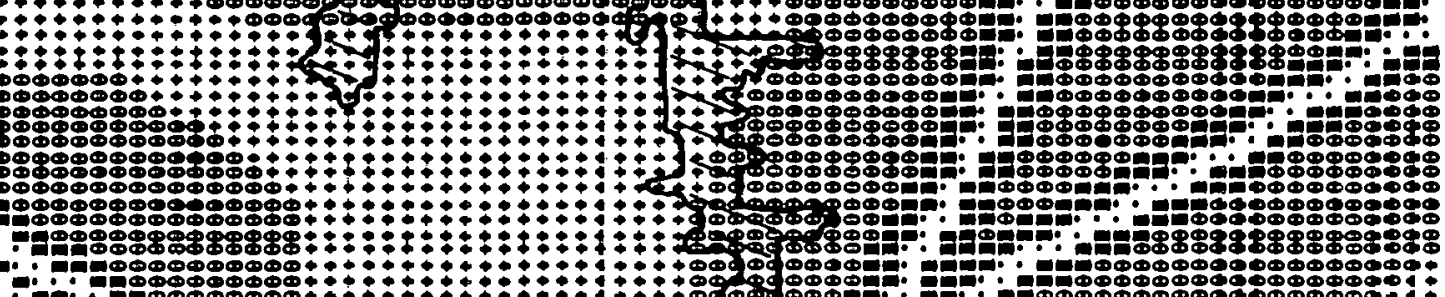

tryt

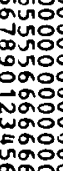

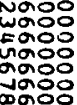

|

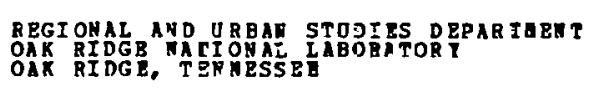

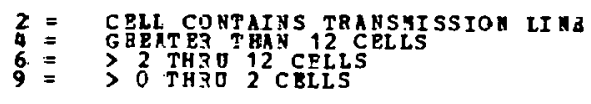

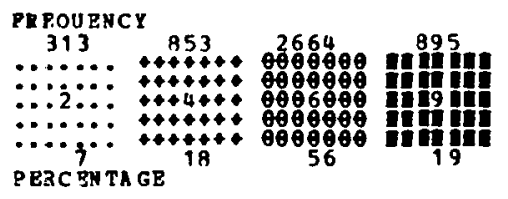

Fig. 18. Kentucky Lake NEC surrogate area: proximity to transmission lines $(>69 \mathrm{kV})$. Scele: 1:590,000. 
ORNL-DWG-75-11751

Koobo8ooo

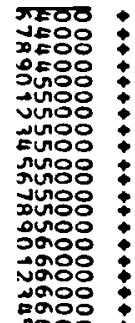

så․․

มูกำำ

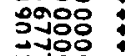

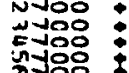

건ำ

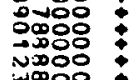

N⿴囗十

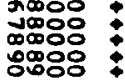

Nim:

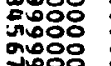

6000

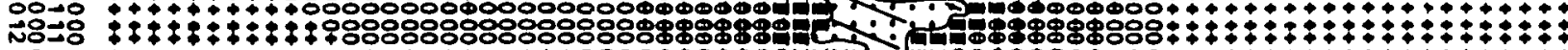

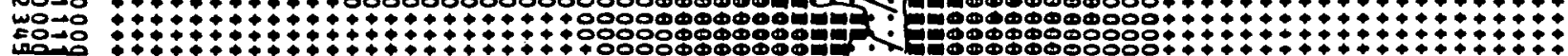

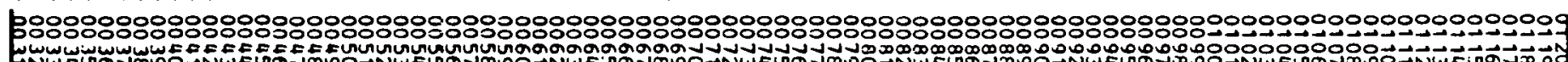

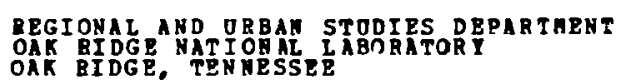

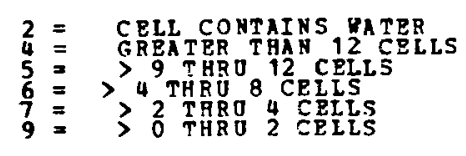

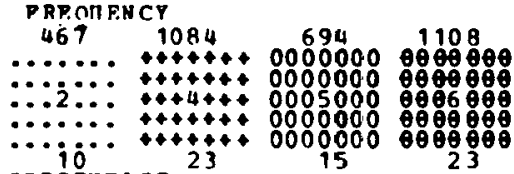
EERCETTAGE

Fig. 19. Kentucky Lake NEC surrogate area: proximity to water. Scale: $1: 560,000$. 
were assigned to each cell. The map of railroads for the Kentucky Lake area has been combined with the map of transmission lines and is contained in Fig. 20. The Kentucky Lake area contains one rail line running across the center of the region from east to west.

\subsection{Roadways}

Roadways also give a partial measure of accessibility for materials, fuels, and waste shipment as well as for commuting of the labor force. Roadways were digitized from the USGS maps. Values were assigned to cells indicating presence or absence of three categories of roads: (1) mediumduty (four lane); (2) light-duty (two-lane); and (3) both medium- and light-duty. A map of the road network in the Kentucky Lake region is displayed in Fig. 21. The figure identifies the presence of a major roadway (U.S. Koute 79 ) extending across the study area from Paris to

Puryear to the Fort Campbell-Clarksville areas. A connector system tying most of the study area to Route 79 exists. Indeed, some $21 \%$ of the cells contain a road of some type.

\subsection{Seismicity}

Selsmicity of the cells is classitied by a single number representing the expected range of acceleration at the bedrock surface heneath the site during the Safe Shutdown Earthquake (SSE). The acceleration (see Table 11) was derived by taking into consideration the distance to the epicenter of the SSE, the intensity (modified mercali) of the SSE, and the relation of the SSE or significant event to a fault of the tectonic province.

Seismicity was developed by means of the deterministic approach prescribed in $10 \mathrm{CFR}$ 100, Appendix A. This approach establishes a maximum expected earthquake and locates its closest approach to a specific site by considering all possible relationships between historical earthquake activities and the prevailing tectonic regime and local structure. Once the SSE is located at the closest logical proximity to the site, attenuation characteristics of the specific region are employed to determine the 
ORNL-DWG-75-11743

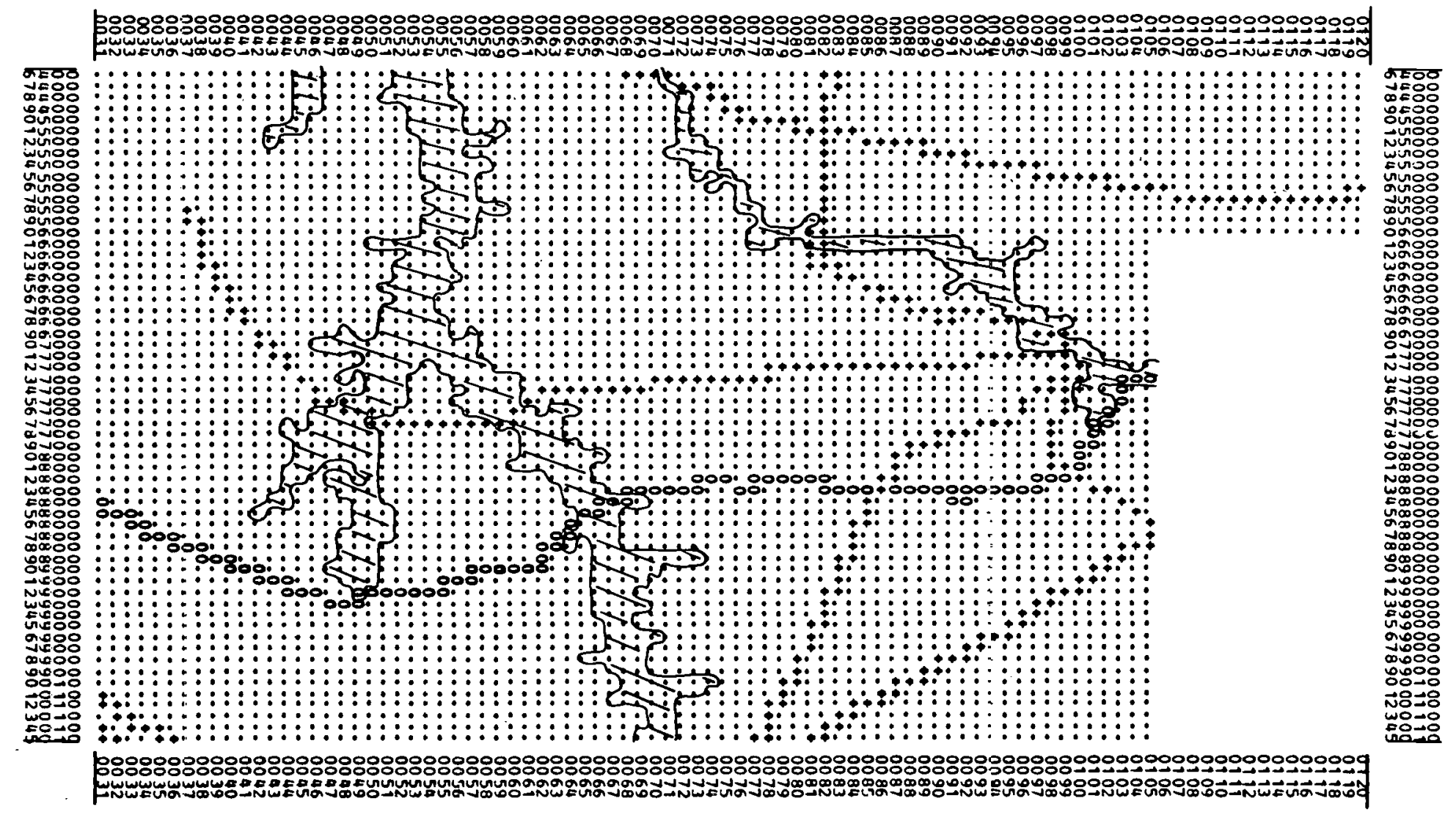

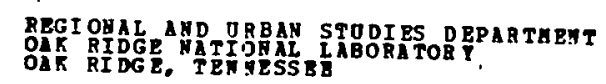

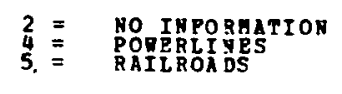

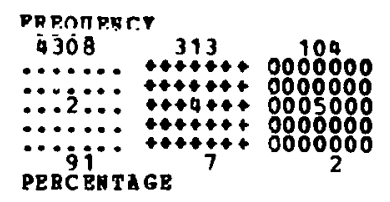

Fig. 20. Kentucky Lake NEC surrogate area: twansportation. Scale: $1: 590,000$. 
ORWL-JW:-75-1.1.745

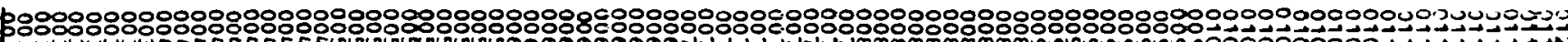

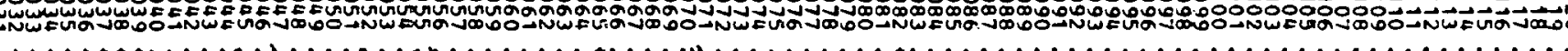

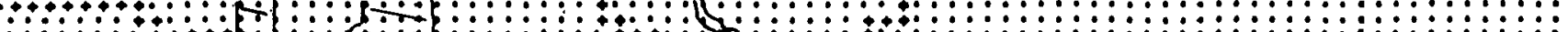

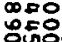

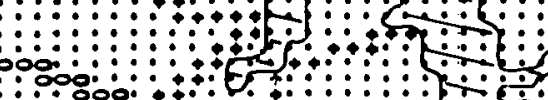

E.

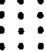
$:: 9980$

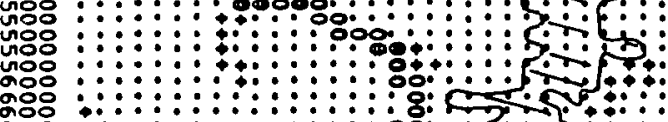

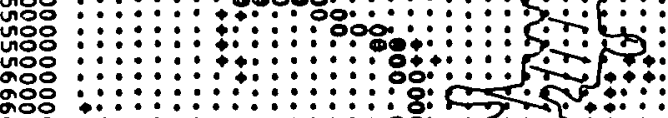

Fin:

:

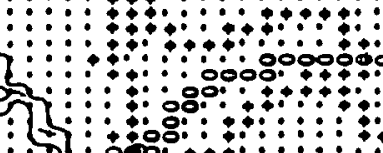

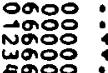

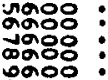

ㄱํำ

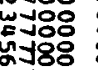

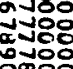

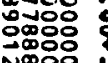

(1)

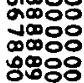

ㄴ.

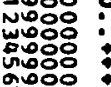

mo

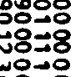

naำ

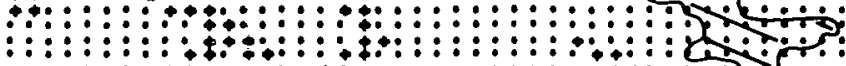

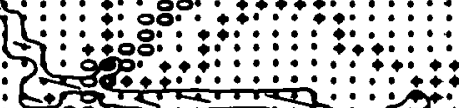

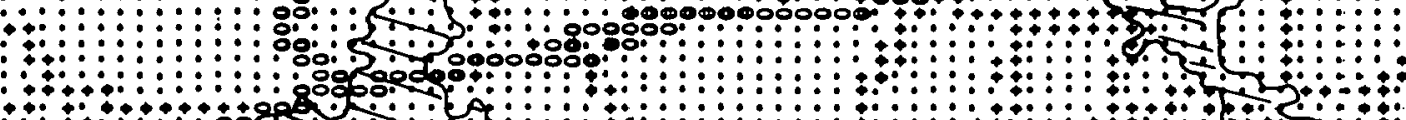

\begin{tabular}{l}
0 \\
\hdashline
\end{tabular}

:000: :

:

(nision

:

:

.

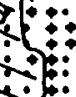

:

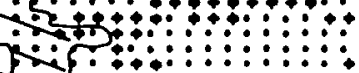

40

(1)

ES

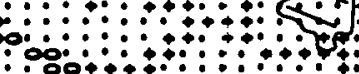

490

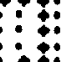

Fifis:

in:

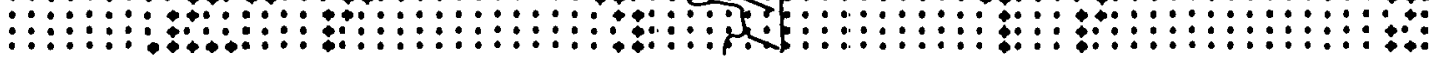

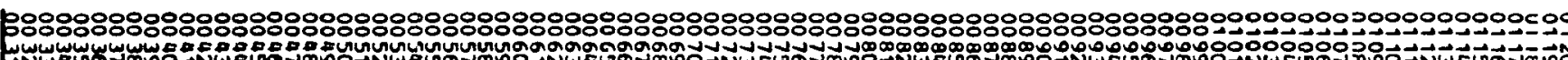

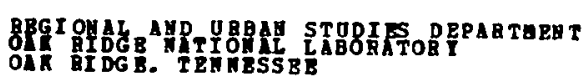

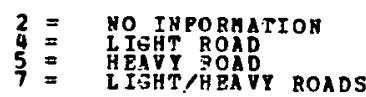

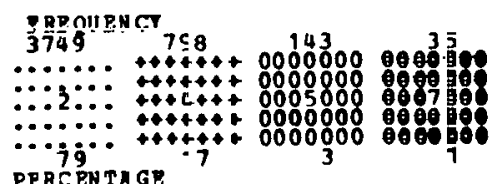

Fig. 21。 Kentıcky Lake NEC surrogate area: Scale: $1: 590,000$

roadways. 
level of acceleration expected in bedrock at various distances from the design event. Appropriate levels of conservatism are applied at each stage of development.

Table 11. Classification of acceleration

\begin{tabular}{cc}
\hline Class number $^{a}$ & Description $(\% g)$ \\
\hline 1 & $0-10$ \\
2 & $11-20$ \\
3 & $21-30$ \\
4 & $31-40$ \\
5 & $>40$ \\
\hline Refers to the single number of seismicity \\
coding.
\end{tabular}

Figure 22 maps seismicity for the Kentucky Lake region. Fortyseven percent of the study area was classified as having an expected range of acceleration greater than $40 \% \mathrm{~g}$. This area covers the northwest half of the region. The remaining area is largely identified in the 21 to $40 \% \mathrm{~g}$ classes. A gradation of acceleration values is prevalent with higher values to the northwest. Using the compatibility information in Table 2, it can be seen that cost increases toward the northwest corner of the region. The southeast corner appears to be the best siting area in terms of seismicity alone.

\subsection{Slope}

A description of the slope of a cell is an indicator of factors such as construction preparation costs, ease of access, and water pumping costs. Slope was converted into digital form through use of the USGS tonpgraphic series maps. The approximate percentage of a cell in three slope classes was indicated. The three slope classes used indicate a gradation of suitability for construction operations. Construction in areas with a slope of $16 \%$ was thought to be difficult. The classes are 0 to $7 \%, 8$ to $15 \%$, and $16 \%$ and greater. Thus, a cell may be coded as $80 \%$ in the 0 to $7 \%$ category, $15 \%$ in the 8 to $15 \%$ category, and $5 \%$ in 
DRNL-ING-75-11755

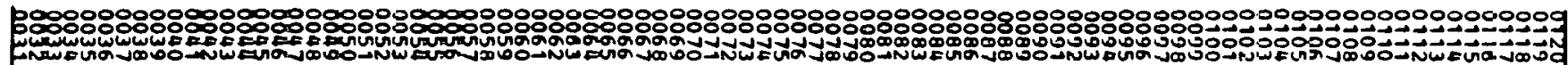

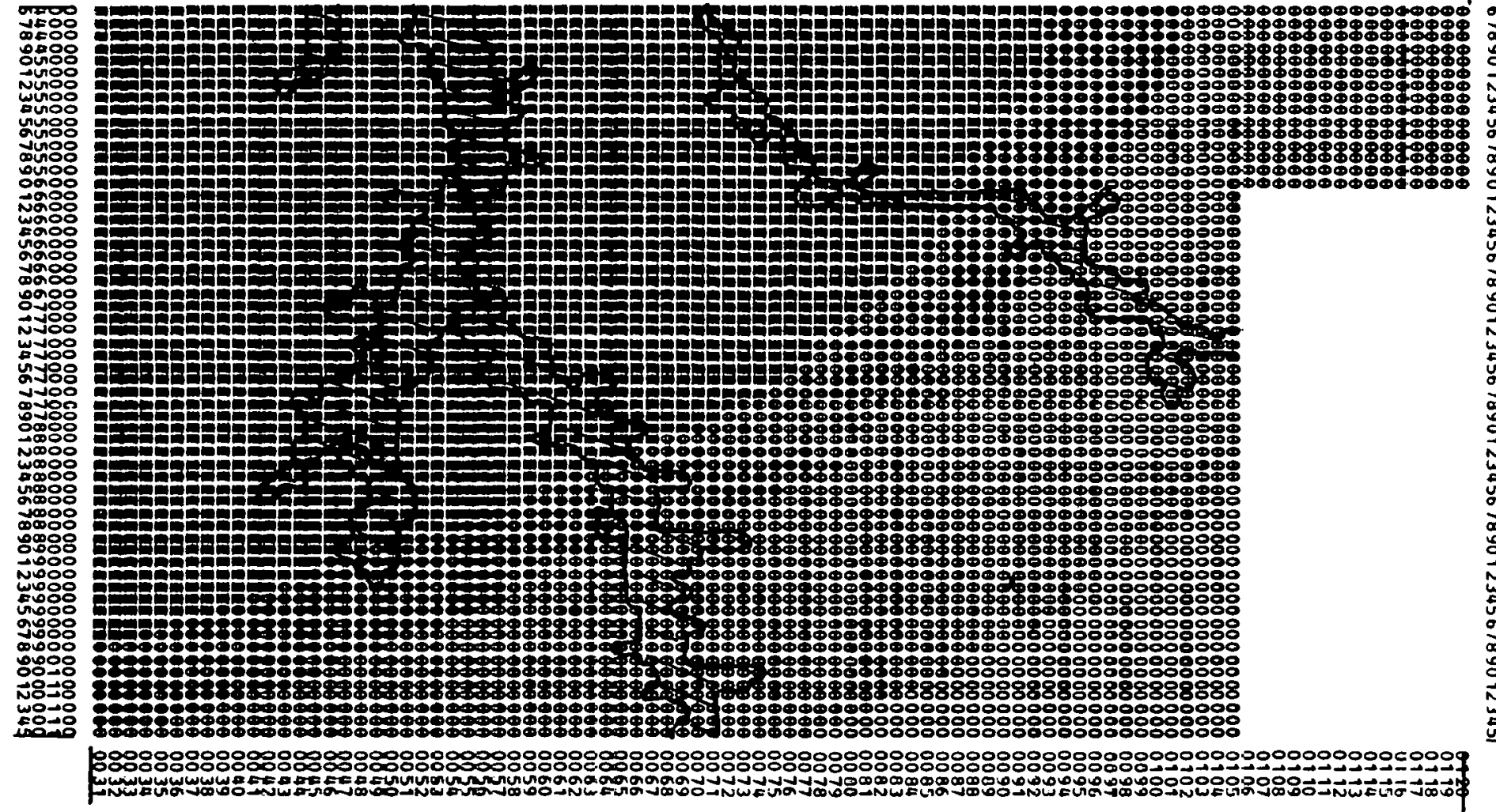

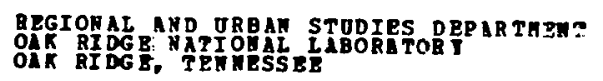
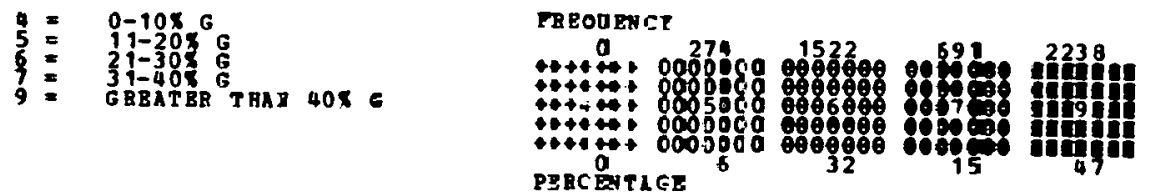

Fig. 22. Kentucky Lake NEC surrogate area: seismicity. Scale: 1:590,000. 
the $16 \%+$ category. These approximate cellular portions were estimated by use of a $10 \times 10$ linear unit grid which fits over each cell (thus, one unit equals $1 \%$ of the cell area). This method avoids the "average slope" measure and yields a more meaningful determination of land surface.

These data were converted into measures of primary and secondary slope. If a cell's primary slope is 8 to $15 \%$, then at 1 east $50 \%$ of the cell was in that class. Maps of primary and secondary slope are contained in Figs. 23 and 24, respectively. The slope maps indicate the roughness of terrain prevalent over a majority of the study area $(62 \%$ of the cells having a primary slope greater than 16\%). The dominant exceptions are in the Fort Campbell area and in the western quarter of the region. Although the Fort Campbell area is relatively flat, the land between it and the Cumberland River has slopes that are generally too steep for construction. Hence, increased cost of water pumping, for example, may offset the lower site preparation costs incurred due to the more level surface. 'lhe land below the embayment is relatively flat and near water.

\subsection{Soils}

Soils were classified by two numbers, the first giving the soil type and mode of deposition and the second giving the soil's predominant thickness (see Tables 12 and 13). Primary, secondary, and tertiary soils were distinguished and classified separately.

The soll types are distinguished mainly on the basis of grain size and mode of deposition. Deposits that normally consist of (1) sand and/or gravel; (2) silt and/or clay; (3) mixtures of sand, gravel, silt, and clay; and (4) residual soils whose composition is dependent on the parent rock are grouped together. Mode of deposition was also included because this parameter conveys important information to experienced geotechnical personnel. Thus, some idea can be gained regarding ranges of thickness, geometry of sedimentary body, degree of sorting, compaction or consolidation, and presence or absence of stratification. The user may also be alerted to the possible presence of soils with certain engineering characteristics (either favorable or unfavorable) that may be common to 
ORIJL-DWG-75-11747

koo8:o8oo:

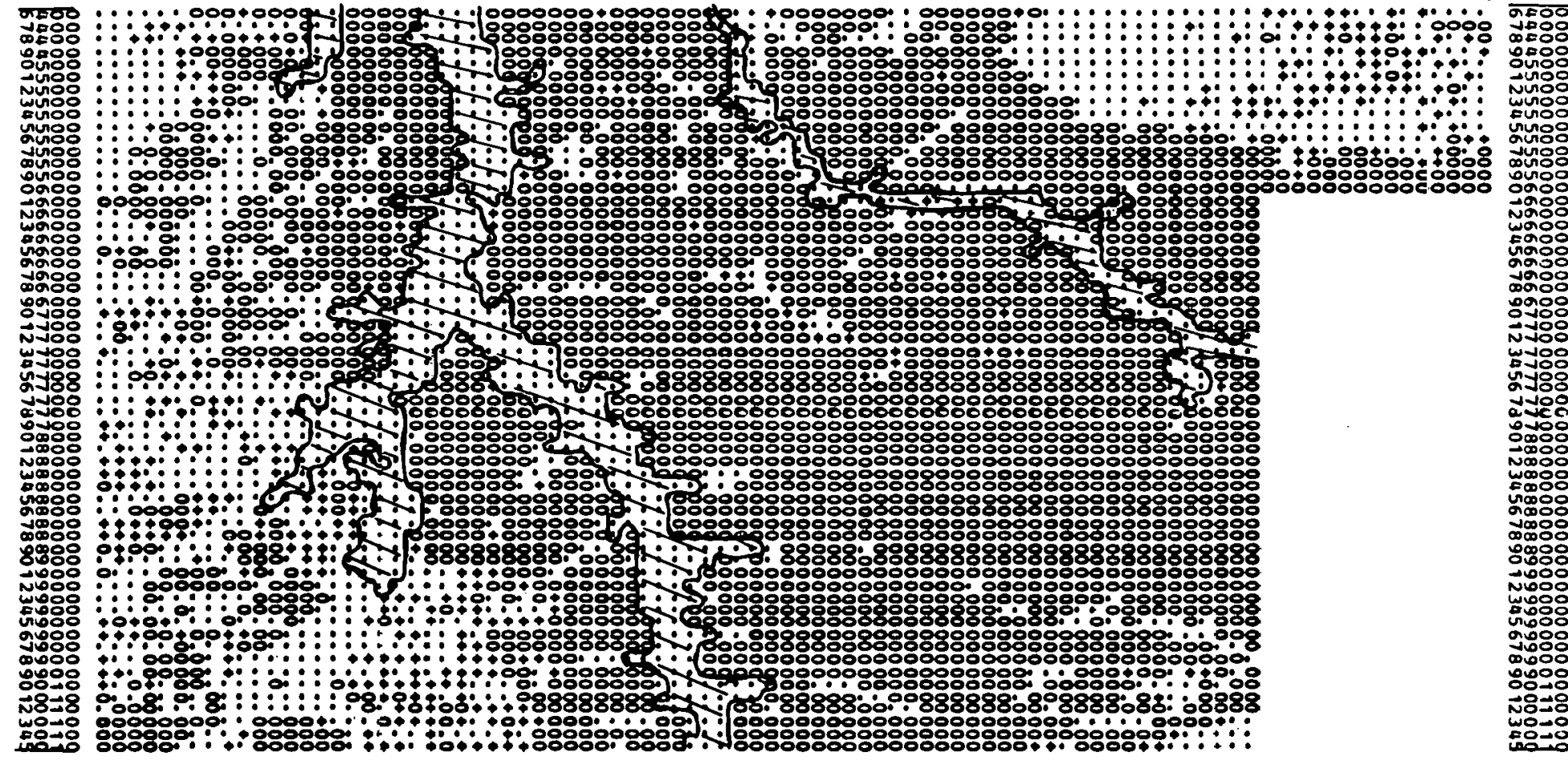

-oo0

|

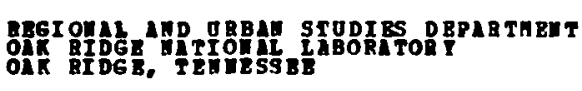

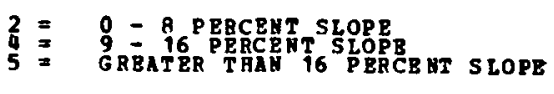

Fig. 23. Kentucky Lake NEC surrogate area: primary slope. Scale: 1:590,000. 
ORNL-DWG-75-11742

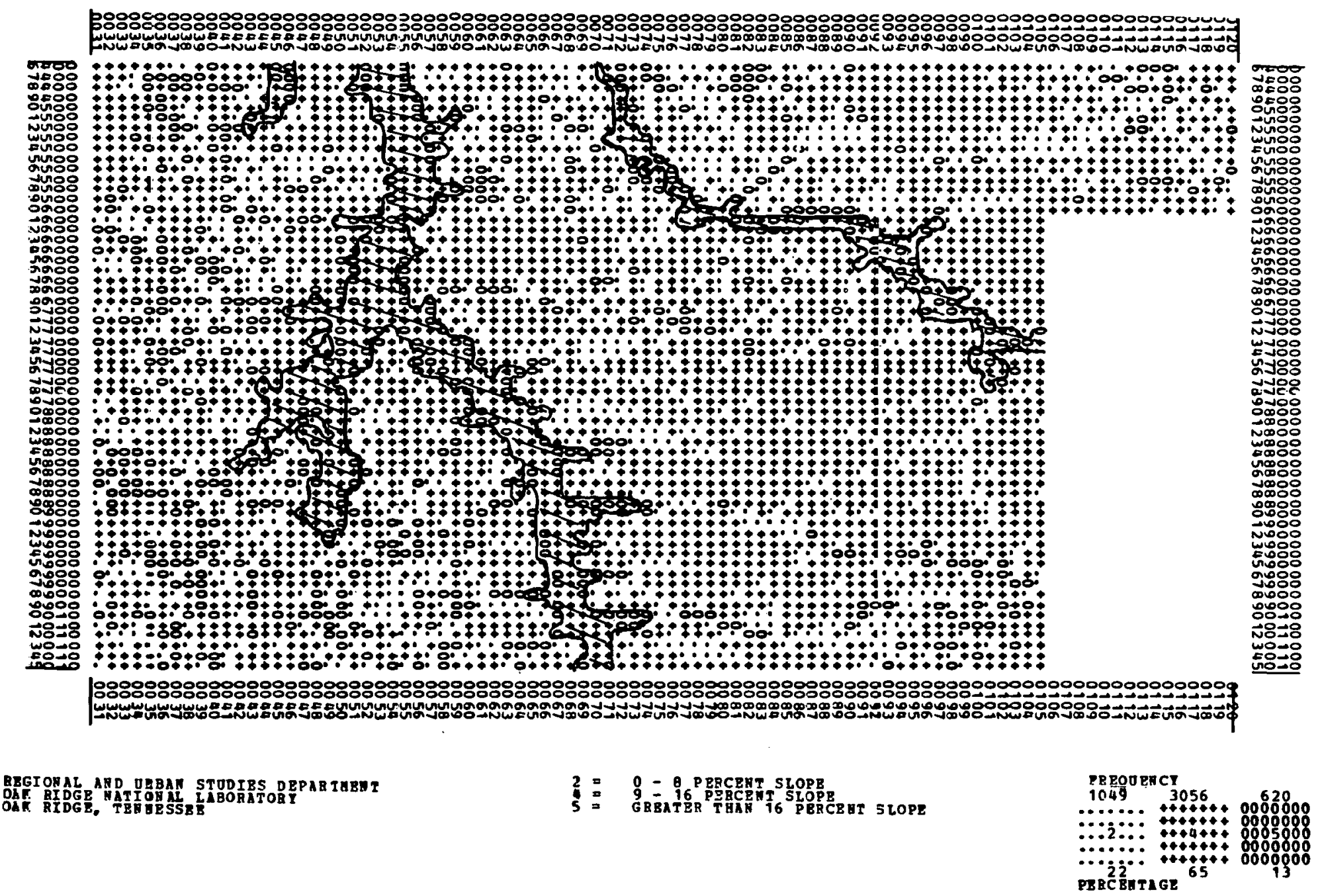

Fig. 24. Kentucky Lake NEC surrogate arəa: secondary slope. Scale: 1: 590,000 。 
Table 12. Classification of soil type

\begin{tabular}{|c|c|c|c|}
\hline Class & number ${ }^{a}$ & Class name & Description \\
\hline & 1 & Continental deposits & $\begin{array}{l}\text { Sand and gravel with silt and } \\
\text { clay; old terrace remnants, } \\
\text { colluvial material; often } \\
\text { appears as a capping unit or as } \\
\text { an upland erosional remant of } \\
\text { a previously blanket-like } \\
\text { deposit. }\end{array}$ \\
\hline & 2 & Marine sand and gravel & $\begin{array}{l}\text { Sand and/or gravel with some } \\
\text { silt and minor clay; possibly } \\
\text { subject to liquefaction. }\end{array}$ \\
\hline & 3 & Marine silt and clay & $\begin{array}{l}\text { With occasional minor sand or } \\
\text { gravel; possibly subject tu } \\
\text { settlement. }\end{array}$ \\
\hline & 4 & Recent alluvium & $\begin{array}{l}\text { Stream deposits of sand and } \\
\text { gravel with some silt and clay; } \\
\text { found in modern streams and } \\
\text { floodplains; possibly subject } \\
\text { to flooding and environmental } \\
\text { constraints. }\end{array}$ \\
\hline & 5 & $\begin{array}{l}\text { Swamp and marsh } \\
\text { deposits, recent beach } \\
\text { sand, dune sand and } \\
\text { loess }\end{array}$ & $\begin{array}{l}\text { Soils generally displaying neg- } \\
\text { ative engineering characteris- } \\
\text { tics or occurring in areas } \\
\text { subject to environmental } \\
\text { constraints. }\end{array}$ \\
\hline & 6 & Glaciofluvial & $\begin{array}{l}\text { Outwash, kame deposits, eskers, } \\
\text { etc.; stratified materials, } \\
\text { mostly sand and gravel, depos- } \\
\text { ited by glacial meltwater. }\end{array}$ \\
\hline & 7 & Glacial till & $\begin{array}{l}\text { Unsorted and unstratified mate- } \\
\text { rial deposited by glacial ice; } \\
\text { includes ground moraines, } \\
\text { druwlins, and terminal and } \\
\text { recessional moraines. }\end{array}$ \\
\hline & 8 & $\begin{array}{l}\text { Glaciomarine and } \\
\text { glaciolacustrine }\end{array}$ & $\begin{array}{l}\text { Silt and clay; fine-grained, } \\
\text { stratified deposits laid down } \\
\text { in ice-marginal lakes or seas; } \\
\text { subject to settlement. }\end{array}$ \\
\hline$\cdot$ & 9 & Residual soils & $\begin{array}{l}\text { Varied soils, ranging from } \\
\text { lhick saprolites to thin man- } \\
\text { tling soils; may necessitate } \\
\text { excavation to sound rock or } \\
\text { relatively easy stripping. }\end{array}$ \\
\hline
\end{tabular}

$a_{\text {Refers }}$ to first number of primary, secondary, and tertiary soil coding. 
Table 13. Classification of soil thickness

\begin{tabular}{cc}
\hline Class number ${ }^{a}$ & Description (ft) \\
\hline 1 & $<10$ \\
2 & $0-50$ \\
3 & $50-100$ \\
4 & $0-100$ \\
5 & $>100$ \\
\hline$a_{\text {Refers to second number of primary, second- }}$ \\
ary, and tertiary soil coding.
\end{tabular}

a particular depositional environment (e.g., soft clays in glaciolacustrine deposits). A single class (class 5) includes soils of various types and modes of deposition, all of which generally display negative engineering characteristics. Figure 25 contains a map of soil types for the Kentucky Lake area. The eastern two-thirds of the area consists of residual soils, whereas the western portion contains continental deposits, marine sand and gravel, recent alluvium, swamp and marsh deposits, and sand and loess.

The limits of the soil thickness classes were selected to take into account available data, ranges of variability in regional soil thickness, and critical thicknesses that might affect nuclear power plant siting. Soils less than $10 \mathrm{ft}$ in thickness would be insignificant and could be easily excavated. Soils ranging from 0 to $50 \mathrm{ft}$ in thickness are also excavatable, but would be considered negative factors if sites with thinner soil cover are avallable. Overburden ranging from 50 to $100 \mathrm{ft}$ in thickness would be still less desirable because of increased excavation costs and stability problems and the possible necessity of founding in soil. Such sites would not be desirable unless dense stable soils were present. Areas classed as having soils ranging from 0 to $100 \mathrm{ft}$ in thickness either display extreme variation in thickness or indicate a. lack of spectfic data. Figure 26 contains a map of soil thickness for the Kentucky Lake area. The map illustrates that the area to the east of the Tennessee River is characterized by thin soils (less than $10 \mathrm{ft}$ thlck). The western region contains fluctuating soils ( 0 to $100 \mathrm{ft}$ thick) and very deep sulls (greater than $100 \mathrm{ft}$ thlck). 
ORIVL-DWG-75-11750
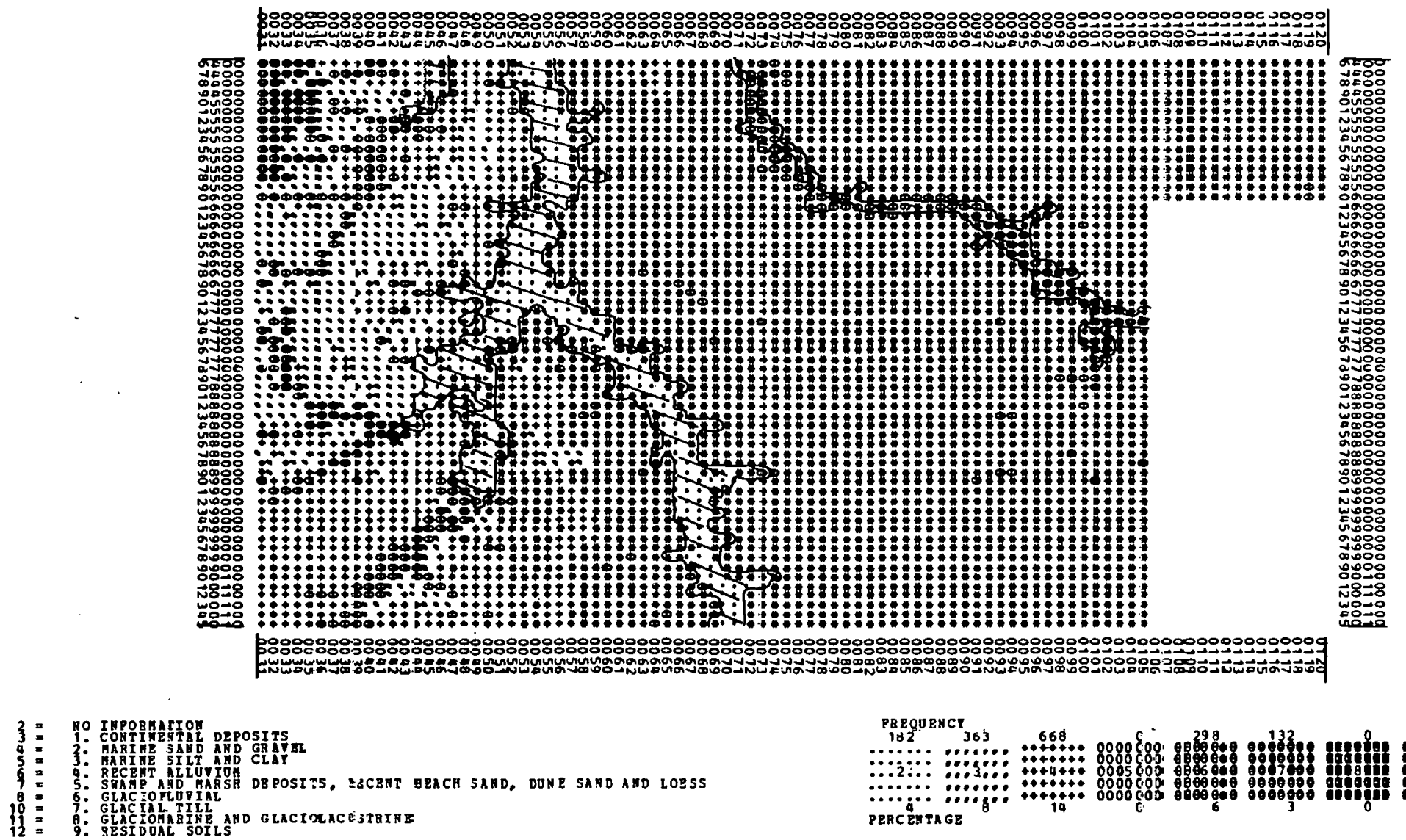

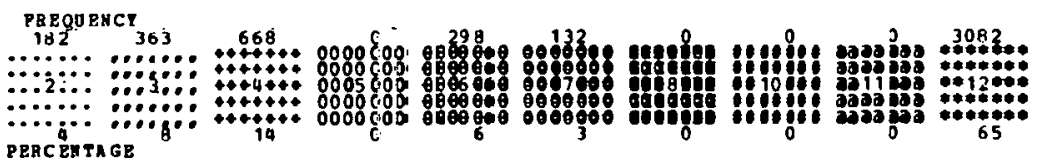

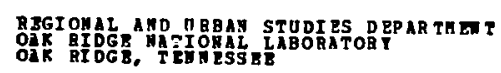

Fig. 25. Kentucky Lake NEC surrogate area: classification of scil type. Scale: 1:700,000. 
ORNL-DWG-75-11757

Ko808:o8o

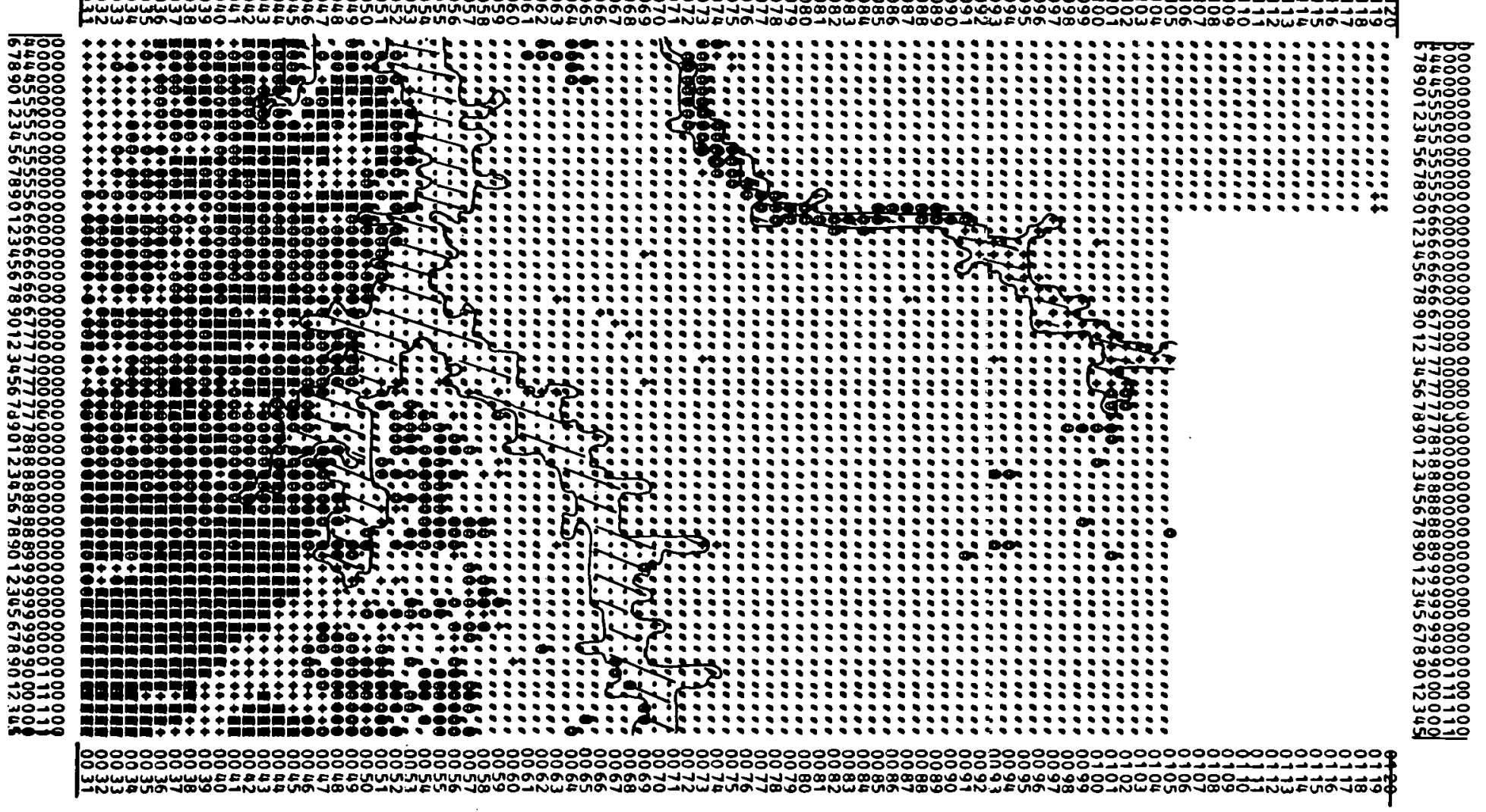

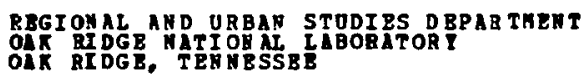

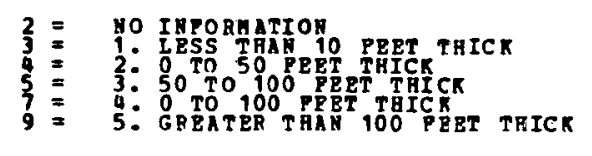

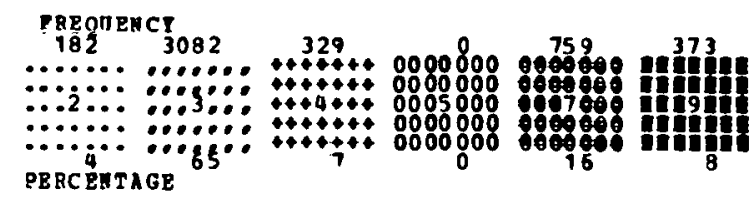

Fig. 26. Kentucky Lake NEC surrogate area: classification of soil thickness. Scale: 1:590,000. 
The compatibility information in Table 13 indicates the interdependence of soil thickness and type in defining compatibility with an NEC. Generally, in comparison with the eastern area of thin soils, the western third of the region appears less suitable for NEC siting based on soil information. Marshy, swampy soils are prevalent in the northwest corner of the region.

\subsection{Transmission Lines}

The presence of existing transmission lines may be beneficial to NEC site location because power for construction would already be available. In addition, the existing corridor may be able to support additional transmission lines carrying a portion of the power from the NEC. Transmission lines were digitized on the basis of the presence or absence of a line of greater than $69 \mathrm{kV}$ in a cell. The corridors were identified from USGS and TVA maps. A map of the transmission network in the Kentucky Lake area is reproduced in Fig. 26. A number of lines exist in the eastern half of the region, and one line extends across to the northwestern segment of the study area.

\section{15 Suitahi 1 it.y}

Figure 27 is a display of sultability scores. This plot is similar to those just reviewed for the single variables. In this case, however, the data categories within the variables are replaced by ranges of cell suitability index scores. These were calculated in the manner described in Sect. 4.2. Therefore, for example, the cell for which the index $(-0.15)$ was calculated in Table 5 would be represented in the plot by a zero, and the cell for which the index (0.28) was calculated in Table 6 would be represented by a zero with an overprinted $X$. The latter, being a higher score and therefore more suitable, would be represented by a

darker shade. The frequency distribution indicates a rather normal distribution of cells in various shades. However, the spatial distribution of the categories is less random than this numeric pattern. Rather, there is a distinct clustering of unsuitable (light) and suitable (dark) cells. For example, a rather unsuitable area exists about midway between the 
ORNL-DWG-75-11995

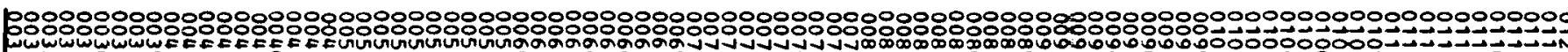

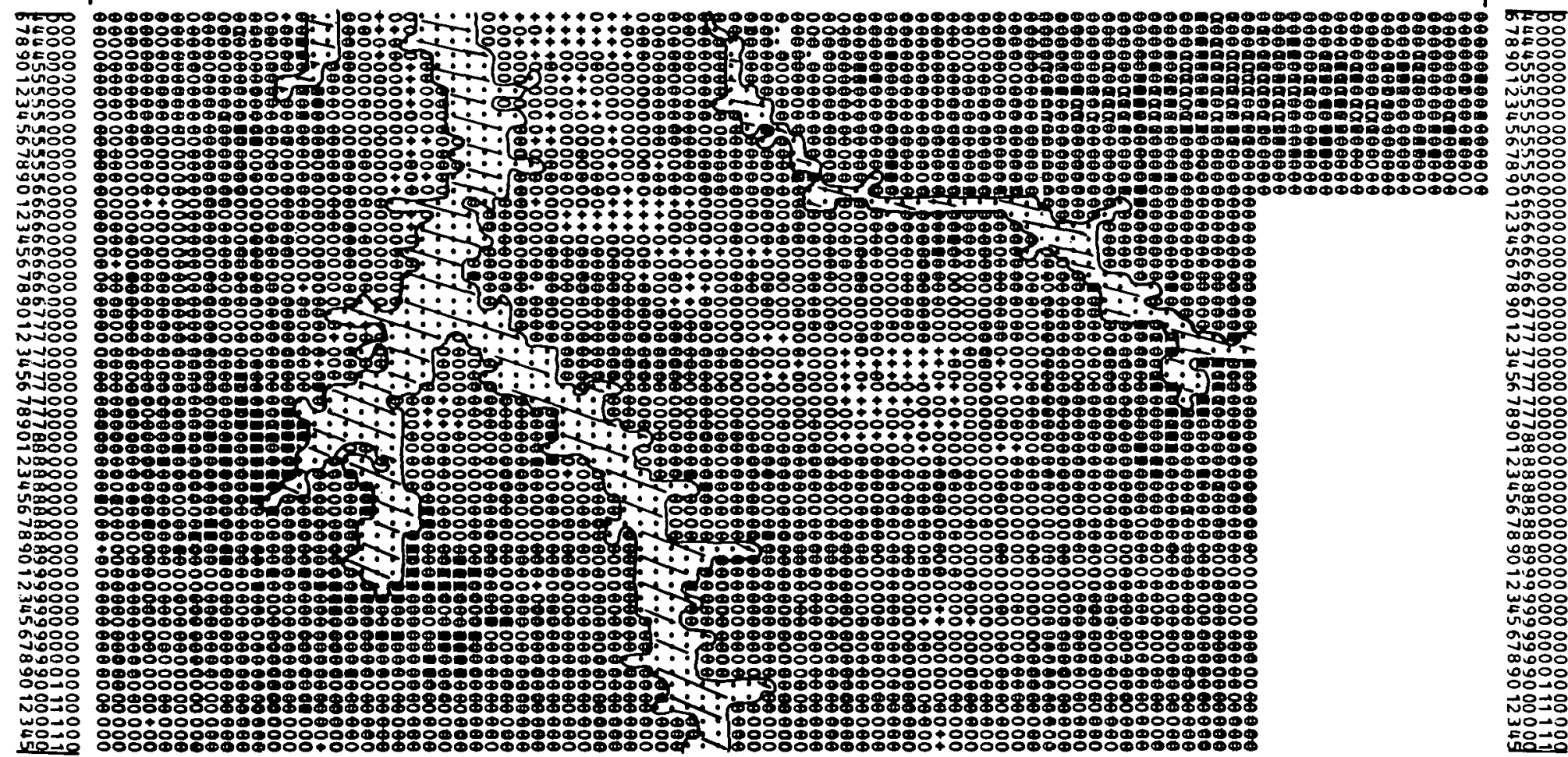

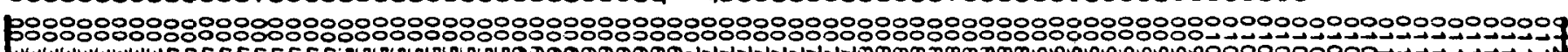

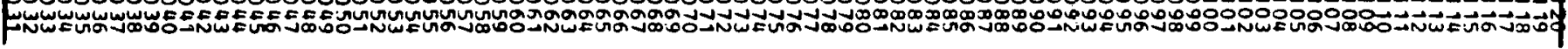

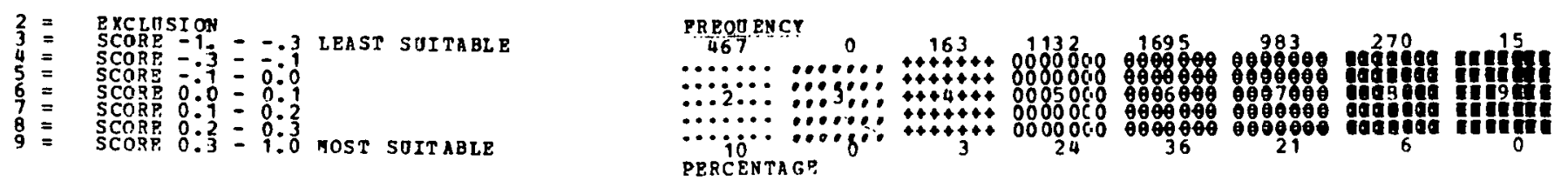

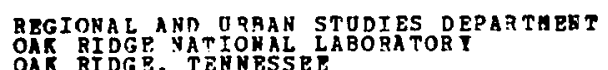

Fig. 27. Suitability scores for Kentucky Lake surrogate area. Scale: $1: 570,000$. 
Cumberland River and Kentucky Lake. The reasons for this may be varied, and examination of the single variable plots to determine why this pattern occurred is possible. As will be shown in the following paragraphs, however, this cumbersome procedure of reviewing plots is not necessary.

Figure 28 shows the approximate location of the ten quad units used tor analysis in Vols. IL and $1 \perp 1$ and outlines clusters of cells that appear to be advantageous for supporting quad units. The figure represents a cursory visual analysis. The outlines were produced by finding dark clusters of cells. The boundaries were then drawn by using cells with scores between 0.2 and 0.3 (level 8) as outer extremities. Theoret1cally, the area within the boundary should have a higher average score per cell than other blocks of cells in the study area.

The plot suggests that the cells that were used for analysis (in the south central part of the study area) were not as suitable as groups of cells in other parts of the study area. As shown in Fig. 28, a more likely area appears to be the cluster of high-scoring cells in the westernmost area outlined. The triangles represent hypothetical quad units. To comply with meteorological requirements, a space of about 2.5 miles was maintained between quad units.

As was implied, this visual analysis is qualitative and is most useful for a "quick look." If, however, the analyst wishes to quantitatively determine the composition of a given block of cells, he can do so with the aid of the profiling program mentioned earlier. Table 7 displayed the percentages of the entire Kentucky Lake area which are in various data categories. Table 14 is the profile of the blocked area in the western part of the study area. As is shown in the table, the area contains 320 cells. To adhere strictly to the 1 acre/MW guide, a potential NEC should contain about 282 cells of 170 acres each.

To interpret the profile, reference to the key (Table 8) and the table of suitability criteria (Table 2) for NECs is necessary. For example, almost $23 \%$ of the cells in the subarea are in category 2 in the proximity to water areas variable. Table 8 shows that category 2 includes cells within two cell spaces of water. Table 2 shows that proximity to water was given an importance of 5 and that the 0- to 2-cell compatibility value was +2 . Therefore, the product of these two values is +10 for 
ORNL-DWG-75-15450

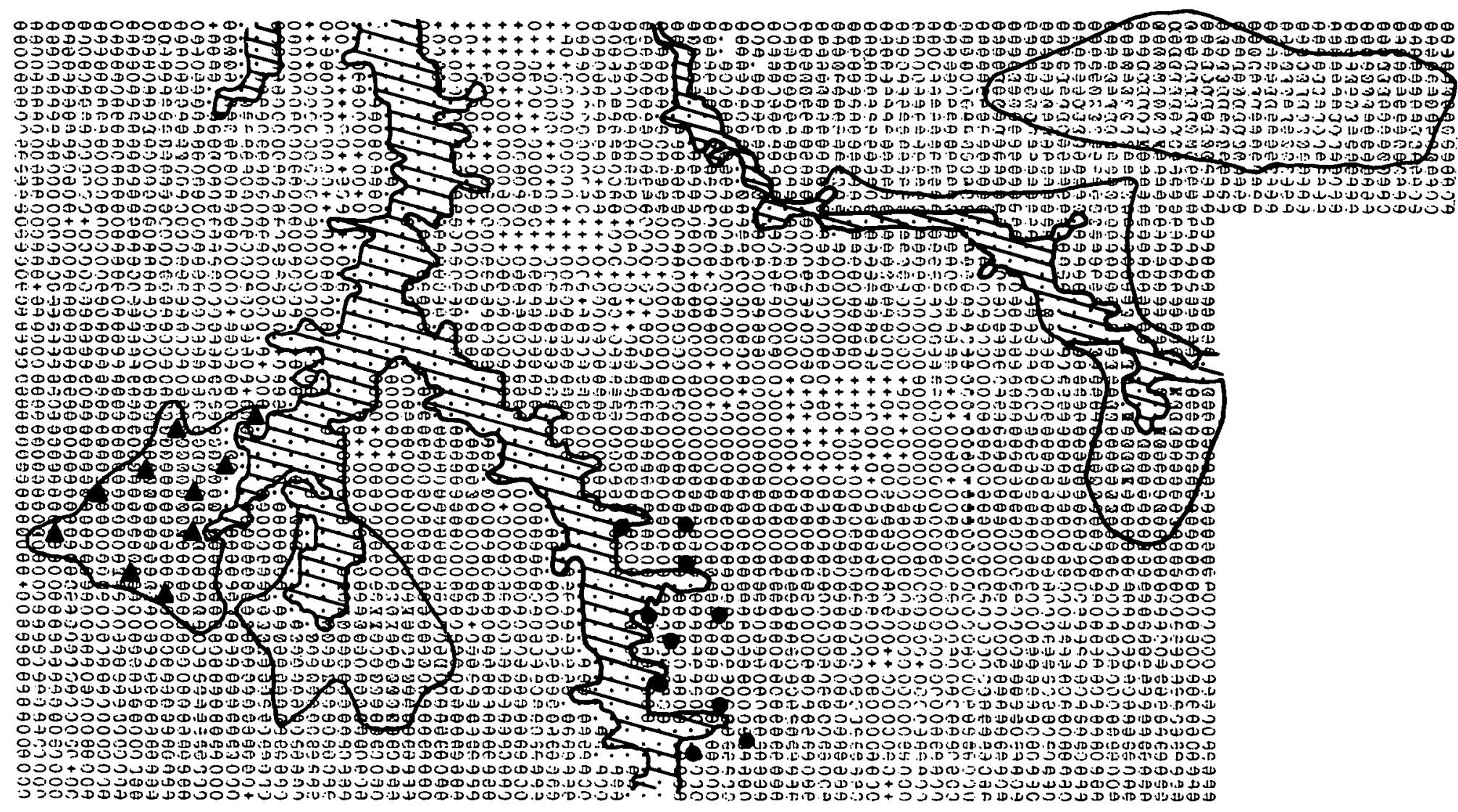
FREQUENCY
$2=$ EXCLUSION
$3=$ SCORE $-7.0--0.3$ LEAST SUITABLE
$4=$ SCORE $-0.3--0.1$
$5=$ SCORE $-0.1-0.0$
$6=$ SCORE $0.0-0.1$
$7=$ SCORE $0.1-0.2$
$8=$ SCORE $0.2-0.3$
$9=$ SCORE $0.3-1.0$ MOST SUITABLE

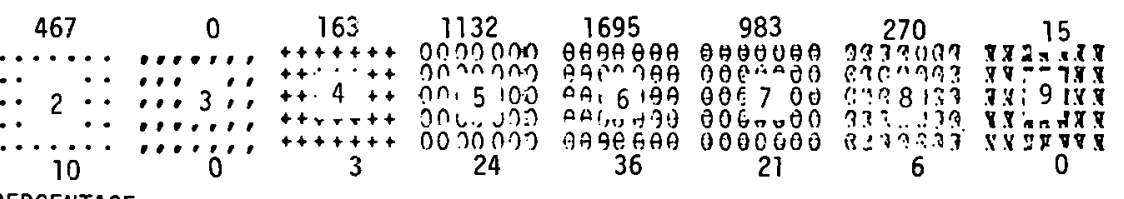

Fig. 28. Aggregations of cells based on suitability scores. Scale: 1:620,000. 
Table 14. Profile for site containing 320 cells with rows 81 through 100 and columns 40 through 55

SOILS

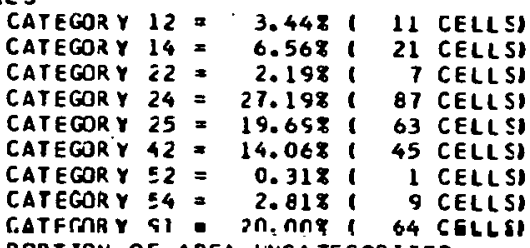
PORTION DF ARFA LiNCATFGRBIIFE = ?.75I

GEOLOGY

CATEGORY $22=21.88 \%, 70$ CELLSI CATEGORY $72=74.378(238$ CELLS) TORTION OF AREA UMCATEGORIZEO = SO'15:

SE ISMICITY

CATEGORY $3=5.698$ (31 CELLSI

CATECORY $4=39.37 \%, 126$ CELLSI

CATEGORY $5=50.9481163$ CELLSI

PORT ION OF AREA UNCA TEGCRIZED $=0.0$

ELEVATION

CATEGORY $I=$ EE.568 213 CELLSI

CATECORY $2=28.138$, SO CELLSI

CATEGORY $3=4.378$ ( 14 CELLS

PORTION OF AREA UNCATEGORIZED $=0.948$

TOPOGR APHIC SLOPE (PRIMARY)

CATEGORY $1=45.068 / 157$ CELLSI

CATEGORY $2=24.068177$ CELLS

CATEGOR $Y$ I $=\angle 6 . \forall 181$ B6 CELLS

PORTION OF AREA UNCATEGORIZED $=0.0$

TOPOGR APHIC SLOPE (SECONDARY)

CATEGORV 1 . 25.948 1 83 CELLSI

CATEEOR $2=39.445$ | LIY LELISI

CATEGORY $3=18.12 \%$ / 58 CELLS

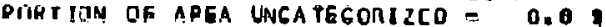

LAND USE IPRIMARYI

CATECORY $1=0.54813$ CELLSI

CATEGORY $2=13.448143$ CELLS

CATEGORY $3=40.3181129$ CELLSI

CATEGURY $4=45.31 \%$ I 145 CELLS

PORTION OF AREA UNCATEGORIZED $=0.0$

LAND USE ( SECONCARY)

CATEGORY $2=3.138110$ CELLSI

CATEGORY $3=22.15 \% 1$ TI CELLSI

CATEGORY $4=23.128174$ CELLSI

PORTION OF AREA UNCATEGORIZED $=51.568$

LAND USE (TERTIARI)

CATECORY $1=5.84 \% 119$ CELLS

CATECORY $2=1.258$ I CELLSI

CATEGJRY $3=15.63 \%$, 50 CELLS CATEGORY $4=13.128142$ CELLSI

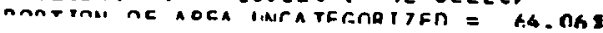

ROADS

CATECORY $1=26.25 \% 1$ O4 CELLSI PORTION OF AREA UNCA TEGORILEO $=73.75$

TRAN SPORTA TION

CATEGORY 2 = C.5E 121 CELLSI

PORTION OF AREA LNCA TEGORIZED $=53.448$

POPULATION OENSITY

CATEQORY $1=55.918$ I 318 LELLSI

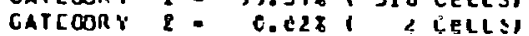

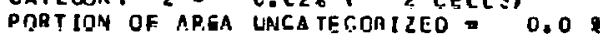

OWN ER SHIP

PORTION OF AREA UNCA IEGORIZED $=.160 .008$

PROPOSED DEVELOFEMENT

CATECORY 2 . 5 .CC. 116 CELLSI

PORTION OF AREA UNCATEGORILED = 55.008

PROXIMIYY IO POPULAIION

CATEGORY $1=10 \mathrm{C} .008$ I 320 CELLSI

PORTION OF AREA LNCATEGORILEO = 0.0 ?

PROXIMITY TO ROAO (LIGHTE LTIHEAYY)

CATEGUAY $1=26.25 \% 184$ CELLSI

CATEGORV $2=49.6581159$ CELLSI

CATEGORY $3=24.06 \% 177$ CELLSI

PORTION OF AREA UNCATEGORIZED $=0.0$ ?

PROXIMITY TO ROAD (HEAVY E LTIHEAVY) CATEGORY $2=1.87 \%$ I A R.FIIS CATEGORY $3=13.448 \mid 43$ CELLSI CATEGORY $4=41.5 E \%$ L 133 CELLSI CATEGORY $5=43.128$ I 138 CELLSI CATEGOR 5 F $43.12 \%$ I 138 CELLSI
PORTION OF AREA UNCATEGORIZEO $=0.0$.

PROXIMITY TO RA ILAOAOS

CAIELORY $1=6.5 E 9$ I 21 CELLSI

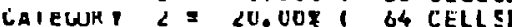

CATEGORY $3=41.878 \mid 134$ CELLS

CATEGORY $4=31.56 \% 1$ 101 CELLSI

PORTIUN OF AREA UNCA TEGORIZEO $=0.0$

PROXIMITY TO TRANSMISSION I.INES

CATEGORY $3=43.75 \%$ | 140 CELLSI

CATEGORY $4=56.25 \% / 180$ CELLSI

NUMI IUN UF AREA UNCA TECONILED = 0.0?

PROXIMITY TO RECREATION AREAS

CATEGOKY $z=1$ = IC.CO\& 320 CELLSI

PORTION OF APEA UNCATEGORIZEO=0.0?

PROXIHITY TO HA TER AREAS

CATEGORY $1=13.448143$ CELLSI

CATFFIRY $2=22.81 .1$ TS CELLS

CATEGORY $3=23.12 \%, 74$ CELLSI

CATEGORY $4=29.3781$ S4 CELLS

CATEGORY $5=10.54 \% 135$ CELLS:

CATEGORY $6=0.3181$ 1 CELLS

PORTION OF AREA UNCA IEGORIZFD = 0.0 
about $23 \%$ of the cells in the subarea. Because category 3 includes cells that are three or four cell spaces from water areas, it follows that about $46 \%$ of the cells in the subarea are within four spaces of a water supply. Table 15 is the profile that corresponds to the area of cells in the eastern portion of the study area, as shown in Fig. 28.

To make a value judgment as to whether the eastern area is better than the western, or vice versa, is difficult at this point. An algorithm to produce a single measure for comparative purposes has been produced, but several points must be kept in mind about this type of calculation. First, a single measure often tends to hide its components; that is, a score may tend to disguise the meaning of the variables that comprise it. Second, the algorithm that produces the score can emphasize the values of those who devise it. As has been noted previously, application of the method necessarily contains considerable subjectivity. A final score may magnify this shortcoming. Third, as a corollary to the second reason, not only may different interests emphasize different criteria, but the reasoning behind the algorithm may also vary. With a suitability score for each cell already determined, there are several ways of determining a single measure for a predetermined cluster. The following are possible measures: (1) highest total score; (2) highest median score; (3) highest average of the scores; (4) highest average with lowest standard deviation; and (5) combination of 1 through 4.

As a first attempt to use a means of comparison, the highest average with the lowest standard deviation was used. A program was written that calculates this measure for all cell blocks of a predetermined size within the surrogate area. The program operates on the northwest corner in a block of cells and deletes cell blocks that cannot meet the size criterion. For example, a cell that is two spaces north and two spaces east of the southeastern-most cell in the surrogate area cannot serve as the northwest corner of a sixtieen by sixteen block of cells. To include the northeast extension of the surrogate area in the analysis, a fifteen by fifteen cell square was predetermined. Virtually any size block of cells can be used. Moving from the upper left-hand corner across the columns and then down each row, each cell represents the northwesternmost 
Table 15. Profile for site containing 322 cells with rows 65 through 87 and columns 92 through 105

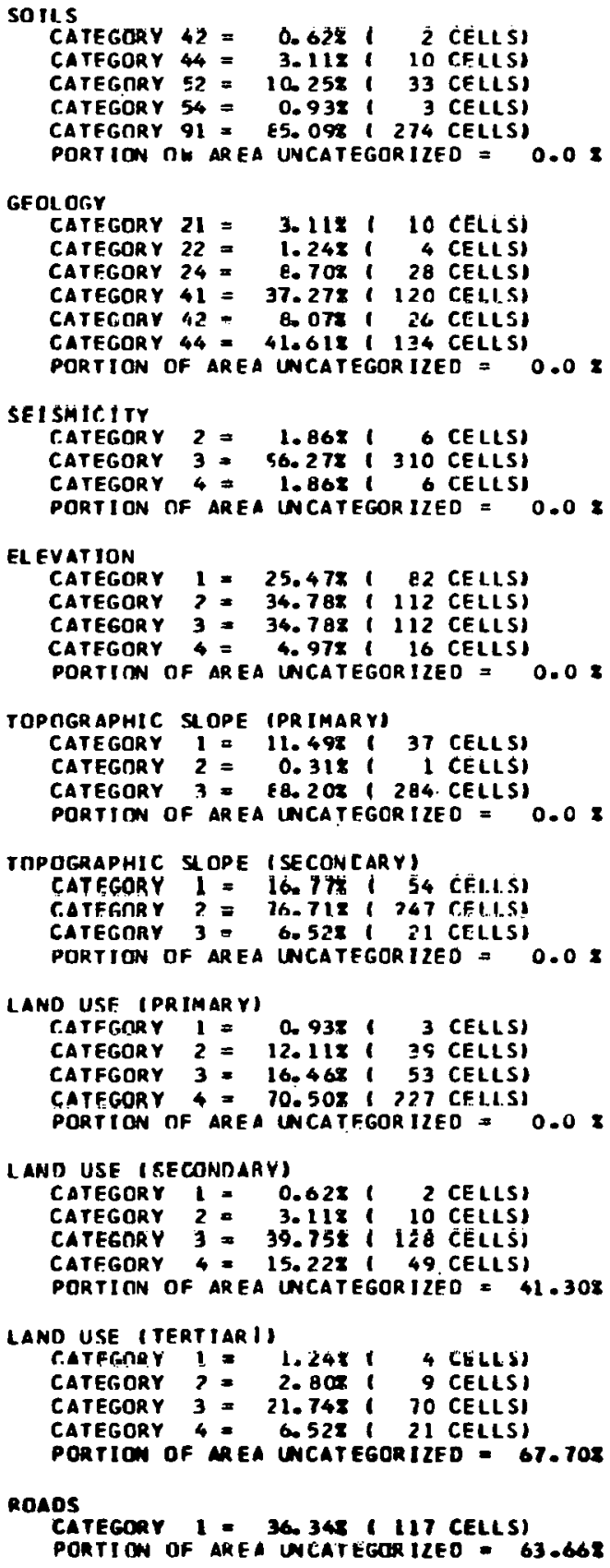


cell in a square block of 225 cells. For each block, the average cell score and standard deviation are calculated. All blocks of cells are then ranked.

The results of this analysis indicated that a block of cells whose northwest cell had coordinates of 46 and 94 was the "best" of the 2821 possible blocks of 225 cells. Parts of this area, and others with high ranks, were included in the area outlined in the northeast extension of the surrogate area. The analys1s also showed that the westernmost area outlined in Fig. 28 had a rank of 113 (of the 2821 possible blocks) when coordinates 76 and 31 are used. Th1s suggests that that area is a highly acceptable site. The outlined area adjacent to it, ranked 418, was also shown to be a fairly good site. Similarly, the area outlined to the snuth nf the Cimherland River was ranked 377. Tho arca on the northern border of the Cumberland River did not lend itself to analysis In this run of the program because of the fifteen by fifteen dimensions. Finally, the surrogate site, analyzed in Vols. II and III, ranked 446, reinforcing the findings of the visual analysis that the site was less than optima1.

Several points should be kept in mind while analyzing the output of the ranking procedure. Depending on the dimension of the block of cells, particular clusters of cells may appear in blocks with high scores and in blocks with low scores. For example, assume that an area larger than 225 cells is comprised of cells with high scores. The block of cells for which an average is being calculated is theoretically moving, cell by cell, across the surrogate area, row by row. Therefore, part of the block may include high-scoring cells, and part may cover low-scoring cells. Consequently, a mediocre average score and rank may result. Relatively few coordinates will then show up as a cluster. It must also be recalled that when such clusters do show up, they are still in the same area. That is, even though a "site" has been defined by. the block size, different sites may represent largely the same area.

This problem might be overcome by the use of a small block size, but this may defeat the analytical advantages offered by the profiling program. Another remedy might be a display that illustrates the output of the 11st of ranked coordinates. This may take the form of a contour 
plot. As yet, none of these methods has been tested. However, one method that may alleviate part of the problem is the production of a suitability plot that can be overlaid on a base map. Figure 29 is such a display. It presents the identical information that was shown on the printer suitability map (Fig. 27). ORNL has acquired the capability of converting from one scale to another and from one projection to another. In this case a map was drawn at the same scale and projection as the USGS 1:125,000 topographic map (which covers the Kentucky Lake area). The mechanical plotter is used for this purpose. With the overlay, the analyst can essentially peer into a particular cell and determine the reasons for its suitability score. Also, since a shading routine is employed, the capability to identify clusters of cells is not lost. This method allows discovery of the shortcomings of a particular cell as well as the implications of its deficiencies.

As a final note, it should be emphasized that the output of the method used in this study is analogous to the output of the more gross coarse screening; it is limited by the considerations (variables) made in the input. Some considerations, such as whether water will be legally or politically (as opposed to technologically and economically) available, have not entered this process. Further, social and socioeconomic issues, for the most part, have not entered the procedure. They must not be neglected, however, in actual siting of an NEC. Therefore, the output displays which, if any, surrogate sites are favorably disposed toward supporting an NEC on the basis of some initial considerations. This, in turn, can give rise to the decision of whether to analyze the area or particular site in more detail or to abandon consideration of an NEC in the particular area. The method is flexible enough to easily accept changes in technology, criteria, or variables. 


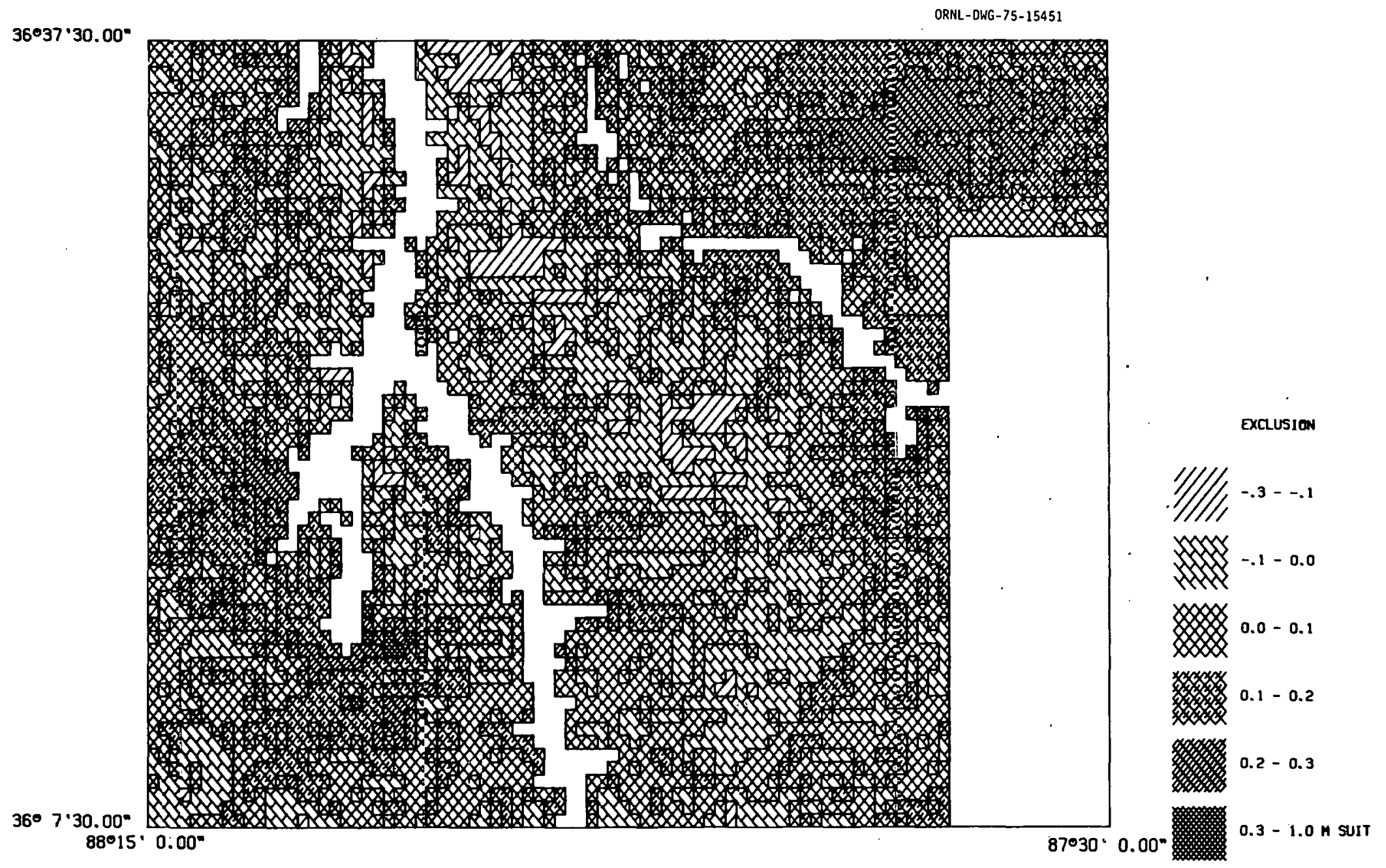

Fig. 29. Ce11 suitability scores in the Kentucky Lake area. Scale: $1: 448,052$. 


\section{REFERENCES}

1. Public Law 93-438, Section 207, October 11, 1974.

2. S. L. Yaffee and C. A. Miller, Toward a Regional Power Plant Siting Method: AEC-Maryland Regional Siting Factors Study (FY 1974 Progress Report), ORNL-TM-4944, November 1974.

3. C. W. Craven, Jr. et al, Regional Environmental systems Analysis Pruypun, ORNL-N3T-ET--74, Oale Ridge National Laboratory, .Tu1y 1974.

4. U.S. Atomic Energy Commission. Regulatory Guide 4.2: Preparation of Environmental. Reports for Nuclear Power Plants, Division of Regulatory Standards, Washington, D.C., March 1973.

5. R. G. Edwards and P. G. Coleman, A Method for Interpolating Population Density from Census Data, in preparation. 


\author{
ORNL/TM-5313 \\ (Fourth Volume of ORNL/TM-5310) \\ Dist. Category UC -80
}

\title{
INTERNAL DISTRIBUTION
}

\section{S. I. Auerbach}

2. J. A. Auxier

3. L. L. Bennett

4-13. C. C. Burwell

14. R. S. Carlsmith

15. C. V. Chester

16. J. E. Cope

17. F. L. Culler

18. G. G. Fee

19. A. P. Fraas

20. W. Fulkerson

21. R. F. Hibbs

22. S. I. Kaplan

23. S. V. Kaye

24. R. L. Lyons

25. R. J. Olsen
26. H. Postma

27. H. P. Raaen

28. C. S. Rosemarin

29. M. W. Rosentha1

30. T. H. Row

31. G. Samuels

32-33. 0. Sisman

34. I. Spiewak

35. E. G. Struxness

36. J. S. Suffern

37. S. L. Yaffee

38-41. Central Research Library

42. Document Reference Section

43-45. Laboratory Records

46. Laboratory Records, ORNL R. C.

47. ORNL Patent Office

\section{EXTERNAL DISTRIBUTION}

48. R. E. Balzhiser, Director, Fossil Fuel and Advanced Systems Division, Electric Power Research Institute, P. 0. Box 10412 Palo Alto, CA 94304

49. S. D. Freeman, 7211 Pyle Road, Bethesda, MD 20034

50. H. Landsberg, Director, Division of Energy and Resource Commodities, Resources for the Future, 1755 Massachusetts Avenue, N.W., Washington, D.C. 20036

51. Louise Markel, Information Officer, Oak Ridge Associated Universities, Institute for Energy Analysis, Oak Ridge, TN 37830

52. I. D. Taylor, Professor of Economics, University of Arizona, Tucson, AZ 85721

53-72. Office of Special Studies Branch, Nuclear Regulatory Commission, Washington, D.C. 20555

73. Director, Research and Technical Support Division, ERDA, ORO

74-198. Given distribution as shown in TID-4500 under General Reactor Technology Category (25 copies - NTIS) 